\title{
Northeast and Northern Forests Regional Climate Hub Assessment of Climate Change Vulnerability and Adaptation and Mitigation Strategies
}

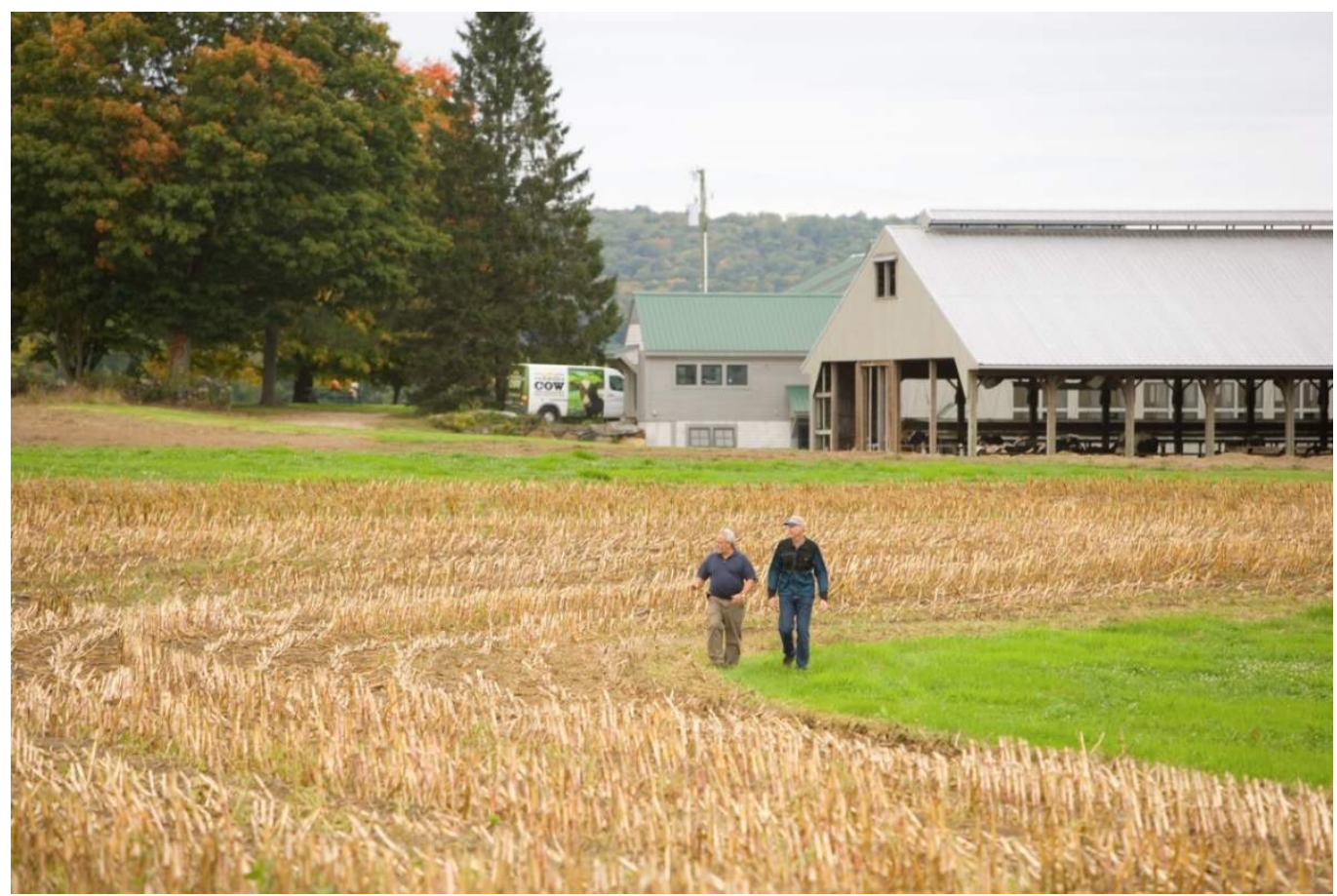

Photo Credit: Scott Bauer (2007)

Authors: Daniel Tobin, The Pennsylvania State University; Maria Janowiak, Northern Forests Sub Hub; David Y. Hollinger, Northeast Hub Lead; R. Howard Skinner, Northeast Hub Co-Director; Christopher Swanston, Northern Forests Sub Hub Lead; Rachel Steele, National Climate Hubs Coordinator, Rama Radhakrishna, The Pennsylvania State University; and Allison Chatrchyan, Cornell University.

Northeast Hub

Northern Research Station USDA Forest Service 271 Mast Rd

Durham, NH 03824

\section{June 2015}

Contributors: Our thanks to Darren Hickman, NRCS; Juliet Bochicchio, RD; Wendy Hall, APHIS; Marlene Cole, APHIS; Sharon Hestvik, RMA; Donna Gibson, ARS; Peter Kleinman, ARS; Lynn Knight, NRCS; Leon Kochian, ARS; Lindsey Rustad, FS; Erin Lane, FS; John Niedzielski, FSA; and Paul Hlubik, FSA. We acknowledge ICF International for its contributions to the Greenhouse Gas Profile. We also acknowledge Pennsylvania State University and Cornell University for their support.

Edited by: Terry Anderson, ARS. 
Suggested Citation: Tobin, D., M. Janowiak, D. Hollinger, R.H.Skinner, C. Swanston, R. Steele, R. Radhakrishna, A. Chatrchyan, D. Hickman, J. Bochicchio, W. Hall, M. Cole, S. Hestvik, D. Gibson, P. Kleinman, L. Knight, L. Kochian, L. Rustad, E. Lane, J. Niedzielski, and P. Hlubik, 2015: Northeast and Northern Forests Regional Climate Hub Assessment of Climate Change Vulnerability and Adaptation and Mitigation Strategies, T. Anderson, Eds., United States Department of Agriculture, 65 pp. http://climatehubs.oce.usda.gov/sites/default/files/Northeast\%20Regional\%20Hub\%20Vulnerability\%20 Assessment \%20Final.pdf

\section{Contents}

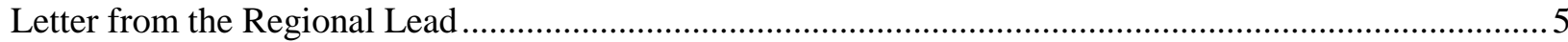

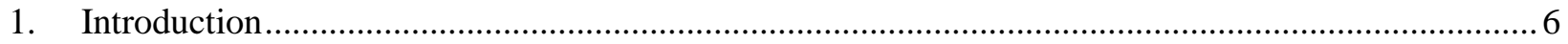

1.1. Description of the Region and Key Resources .................................................................... 6

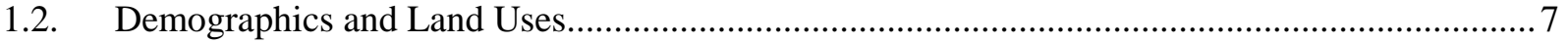

1.3. General Climate Conditions, Extremes, and Past Effects ........................................................ 7

1.4. Summary of Regional Climate Trends and Scenario for the Future .......................................... 7

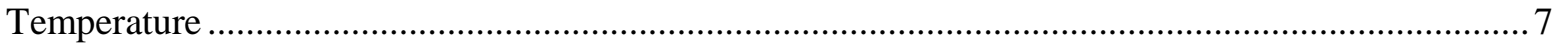

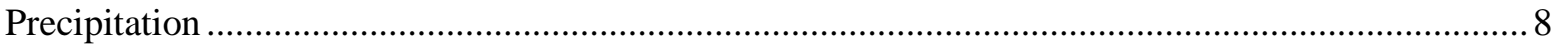

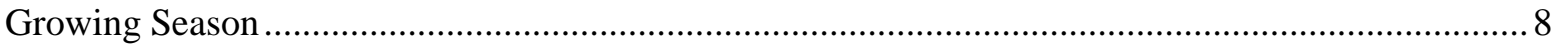

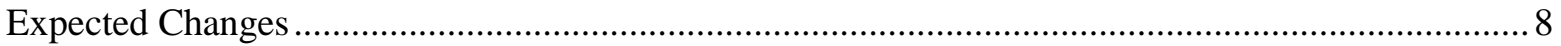

2. General Climate Effects on Agriculture and Forests ................................................................. 9

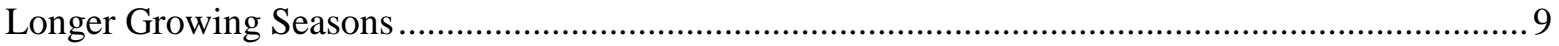

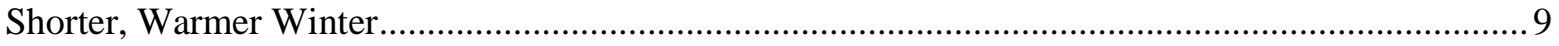

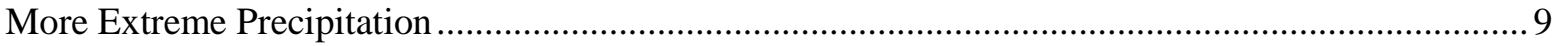

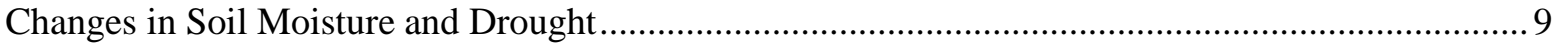

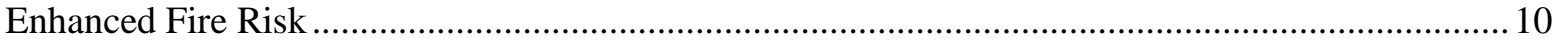

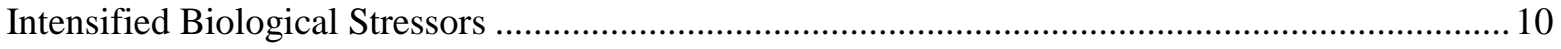

3. Regional Agriculture's Sensitivity to Climate Change and Adaptation Strategies........................... 10

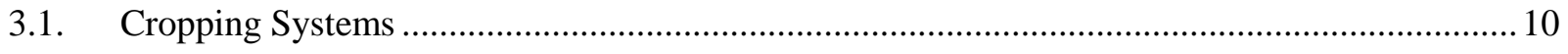

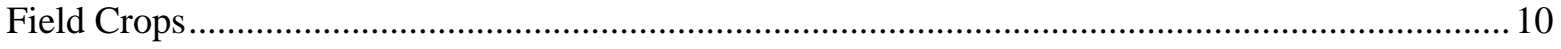

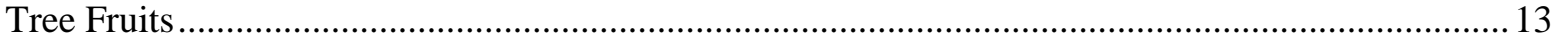

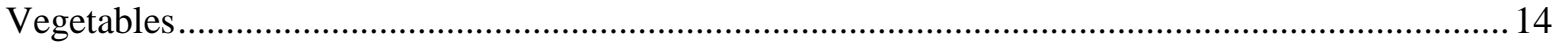

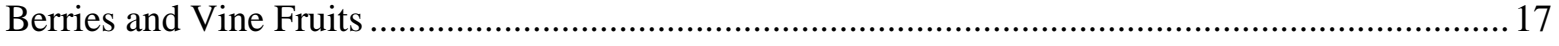

Greenhouse, Nursery, Sod, and Specialty Products ..................................................................... 18

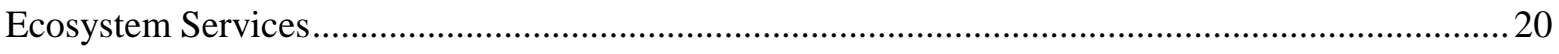

3.2. Livestock Systems Overview of Risks, Vulnerabilities, and General Adaptation Strategies ..... 22

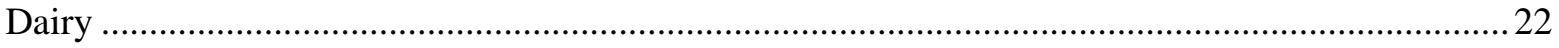

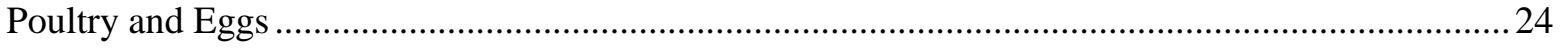




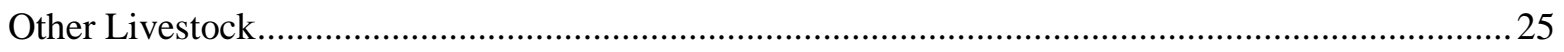

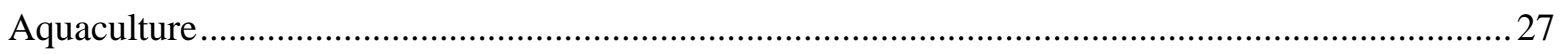

4. Forest Systems Overview of Risks, Vulnerabilities, and General Adaptation Strategies...................28

4.1. Factors That Increase Risk to Ecosystems …......................................................................28

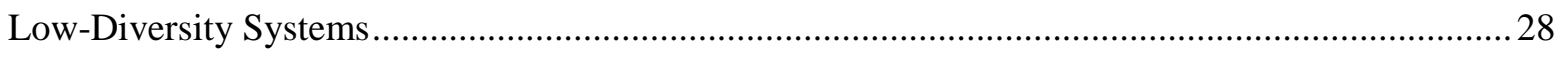

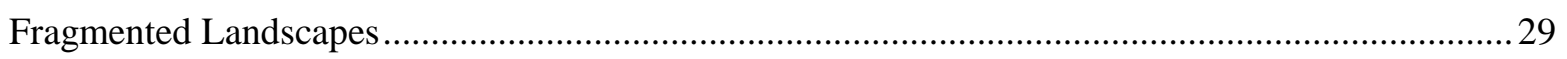

Systems That Are Limited to Particular Environments ................................................................29

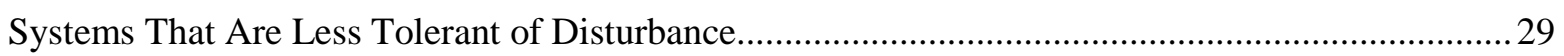

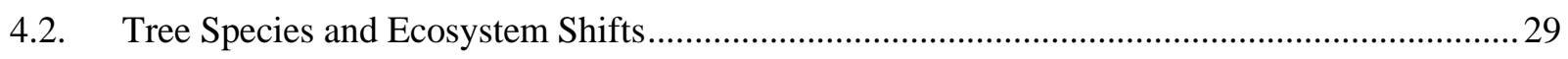

Reduced Habitat for Northern and Boreal Species .....................................................................2

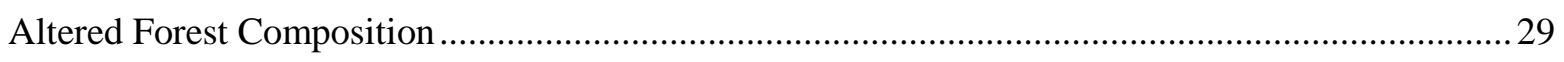

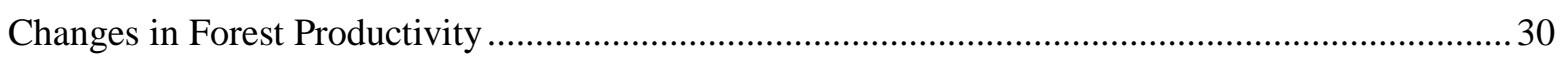

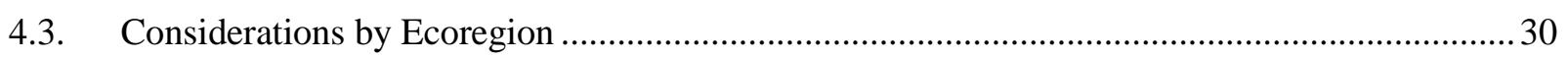

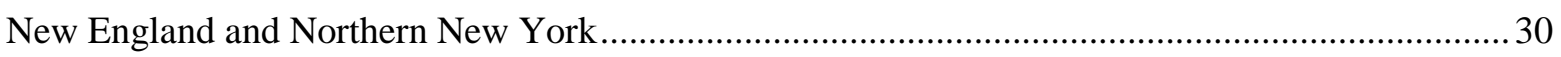

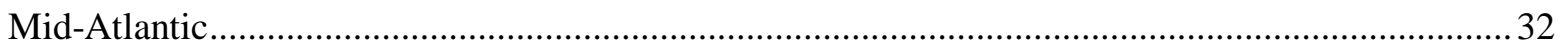

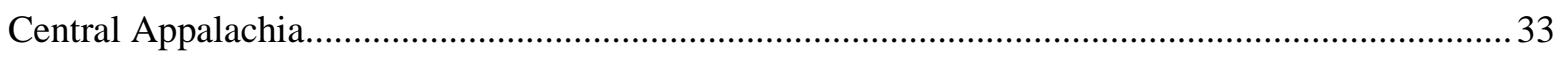

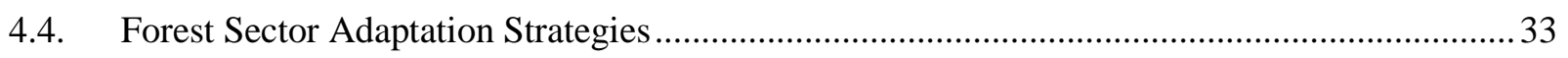

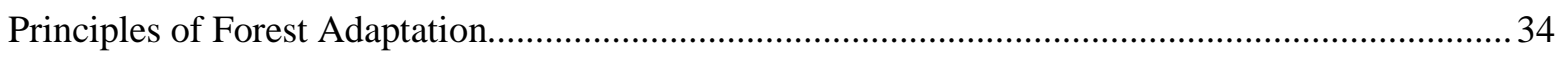

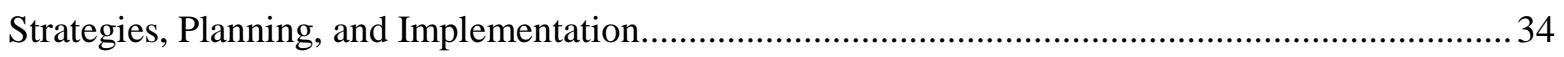

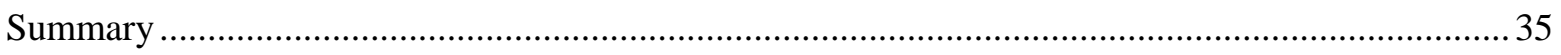

5. Greenhouse Gas Emissions Profile from Agriculture and Forests within the Region and Mitigation

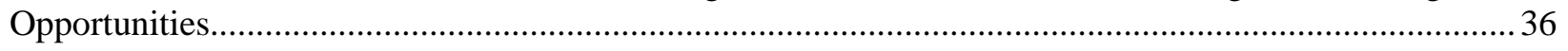

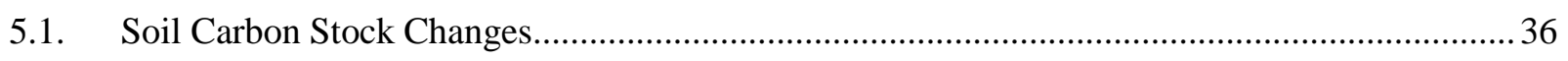

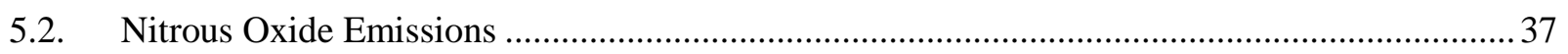

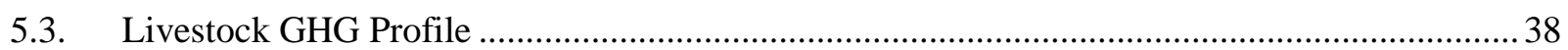

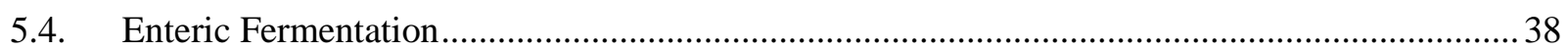

5.5. Emissions from Manure Management Systems ..................................................................... 39

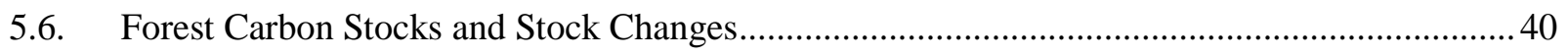

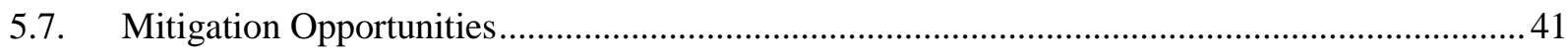

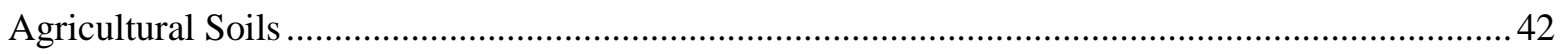

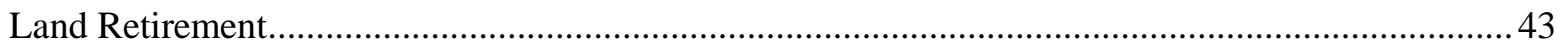

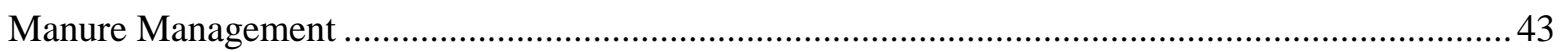

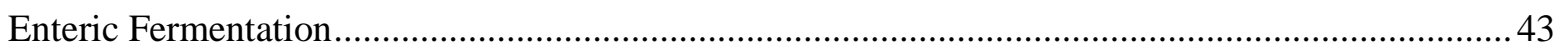

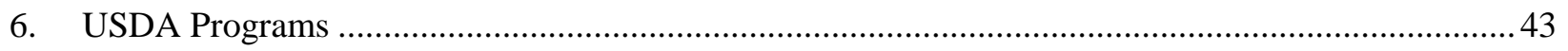

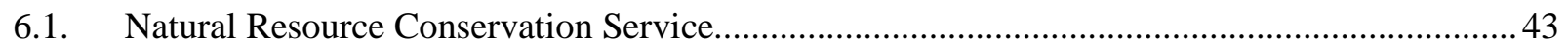




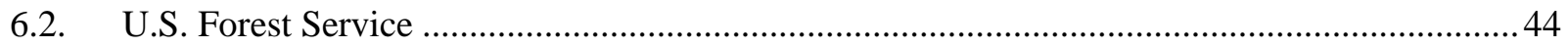

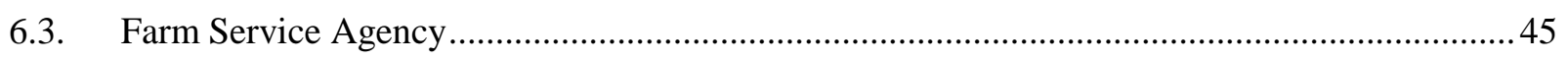

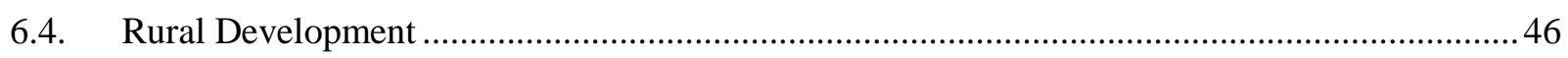

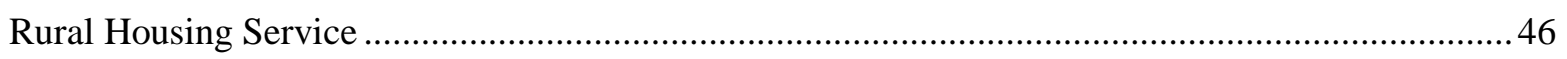

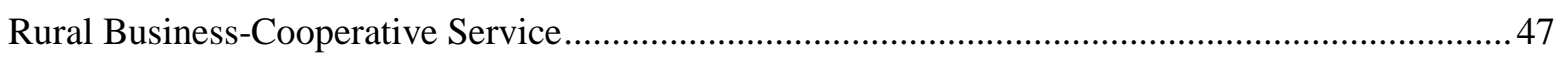

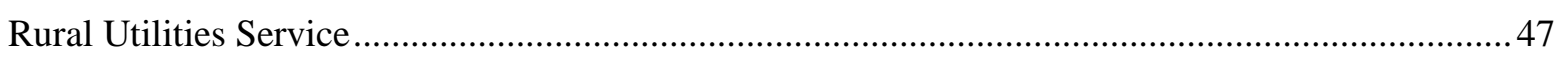

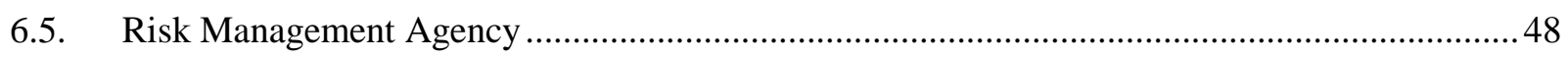

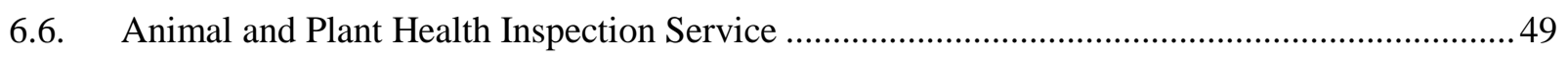

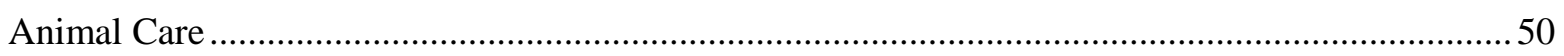

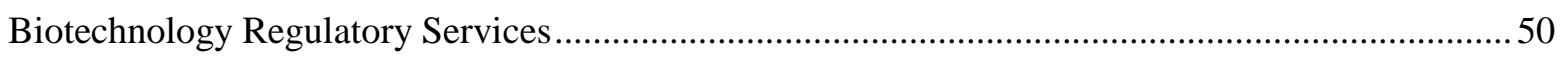

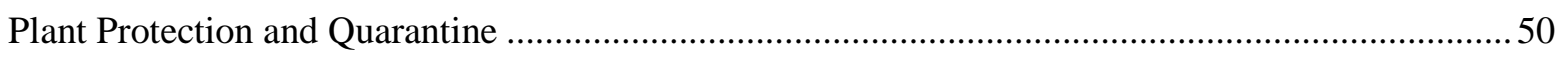

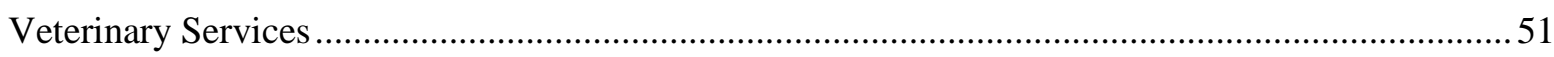

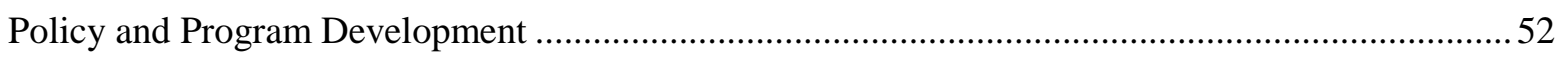

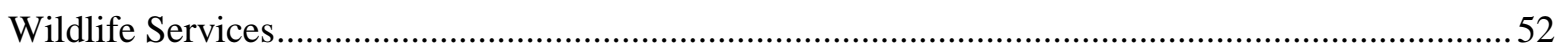

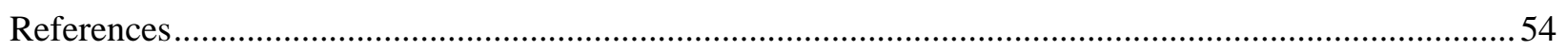




\section{Letter from the Regional Lead}

The Northeast Regional Climate Hub covers Connecticut, Delaware, Maryland, Maine, Massachusetts, New Hampshire, New Jersey, New York, Pennsylvania, Rhode Island, Vermont, West Virginia, and the District of Columbia. The Northern Forests Climate Sub Hub shares this footprint and represents people working and living in the forests of the Northeast.

About 21 percent of land in these 12 States is farmland (6 percent of national total), and 62 percent is classified as timberland (land area covered by trees is somewhat larger). The northeastern United States is home to about 175,000 farms that collectively produce agricultural commodities worth more than $\$ 21$ billion per year. The most important commodities in the Northeast are dairy production and poultry, and about half of the field crops (including pasture) grown in the Northeast are for animal feed. Horticulture is a relatively large portion of total plant production in the Northeast, as are perennial fruits such as apples, pears, blueberries, and cranberries. Farms in the Northeast are on average smaller than in many other parts of the country, and a greater percentage of these are operated by women than in the rest of the United States. Organic production is relatively greater than in most other regions.

According to the National Climate Assessment, the northeastern region of the United States faces an array of climate-related challenges, including heavier rainfall and greater rainfall totals. Additionally, on the basis of data from the National Oceanic and Atmospheric Administration (NOAA) Cooperative Observer Network, it is gradually getting warmer. Regional annual and seasonal temperatures have generally remained above the 1901-1960 average over the last 30 years, with long-term annual and seasonal temperatures trending upward between 0.11 and $0.24^{\circ} \mathrm{F} /$ decade over this time period. Furthermore, the length of the freeze-free season has increased by about 10 days. Crops and forests in the Northeast are also under increasing pressure from weeds, insects, and diseases, and these pest pressures are compounded by the additional stress of variable weather and a changing climate.

More intense and higher rainfall totals increase the burden that agriculture and forest producers face in being able to conduct timely operations. The Northeast Regional Climate Hub is working across a range of crops, forests, and livestock production systems to assemble the available information into tools and practices that can increase the resilience of these systems to climate change. Practices that improve soil health and protect soils from erosion are of particular importance because healthy soils are a key to productivity and resilience.

This vulnerability assessment reviews present knowledge of agricultural and forest susceptibility to climate variability in the Northeast and will serve as a guide to focus future adaptation work. We thank our Land Grant university partners for their leading role in this assessment, especially Daniel Tobin of Pennsylvania State University. We look forward to continuing to work with our partners to identify and encourage practical and cost-effective methods for increasing farm and forest resilience to climate variability and change. The Northeast Regional Climate Hub will work hard to assemble information that serves the needs of producers and increases the value of our research information in educational and outreach efforts.

David Hollinger, Northeast Hub Lead

Howard Skinner, Northeast Hub Co-Lead

Christopher Swanston, Northern Forests Sub Hub Lead 


\section{Northeast Region}

\section{Introduction}

The northeastern United States is a diverse region containing the seven most densely populated States in the Nation. Agriculture in the Northeast is varied, including vegetable production, ornamentals and fruits, animal production, and field crops. Forests are a dominant land use in the northern parts of the region and in the Appalachian Mountains. Northeast farmers are already experiencing crop damage from extreme precipitation. Wet springs are delaying planting and harvest dates and reducing yields for grain and vegetables. Heavy rain in the Northeast has increased more than any other region in the country (Horton et al., 2014).

Despite the trend toward warmer winters, increased risk of frost and freeze damage has been observed over the past decade. Perennial crops (e.g., grapes, apples, cherries) are particularly vulnerable to variable winter temperatures. Extended warm periods in late winter or early spring can cause premature leaf-out or bloom, followed by an extreme frost, costing growers millions of dollars. This scenario played out across parts of the Northeast in spring 2012, when a late frost contributed to a 38 percent decrease in apple yields in New York State. Though longer growing seasons provide opportunity for greater forest growth and agricultural yields, intensified weed and pest pressure (e.g., corn earworm, kudzu) may also result from extended seasons and warmer winters (Horton et al., 2014).

Higher temperatures in the Northeast are already having an effect on tree species distribution. A study in Vermont found an upslope shift of several hundred feet in the boundary between northern hardwoods and boreal forest on the eastern slopes of the Green Mountains between 1964 and 2004 (Horton et al., 2014). Ocean temperatures are also rising, changing the range of suitable habitat for many commercially important fish and shellfish species. Native American communities are observing a range shift in their traditional foods gathered from the forests (Lynn et al., 2013), which may lead to negative health and cultural effects.

The remainder of this report provides an overview of regional agriculture and forest system sensitivities to climate change and adaptation strategies, a greenhouse gas emissions and mitigation profile for the region, and a summary of the U.S. Department of Agriculture (USDA) programs that are vulnerable to a changing climate and what is being done to build resilience on working lands through these programs.

\subsection{Description of the Region and Key Resources}

The northeastern States and District of Columbia encompass more than 20 percent of the U.S. population (U.S. Census Bureau, 2014) but less than 6 percent of the land area. According to the USDA National Agricultural Statistics Service (NASS), 2012 sales of agricultural commodities in the Northeast totaled about $\$ 21$ billion (National Agricultural Statistics Service, 2014a). This value is increased many times when taking into account the marketing and processing of agricultural products. The Northeast is the most heavily forested region in the country, and the combined recreational and manufacturing value of forestry in just the four northern-most States in this region exceeds \$19 billion a year (Shifley et al., 2012).

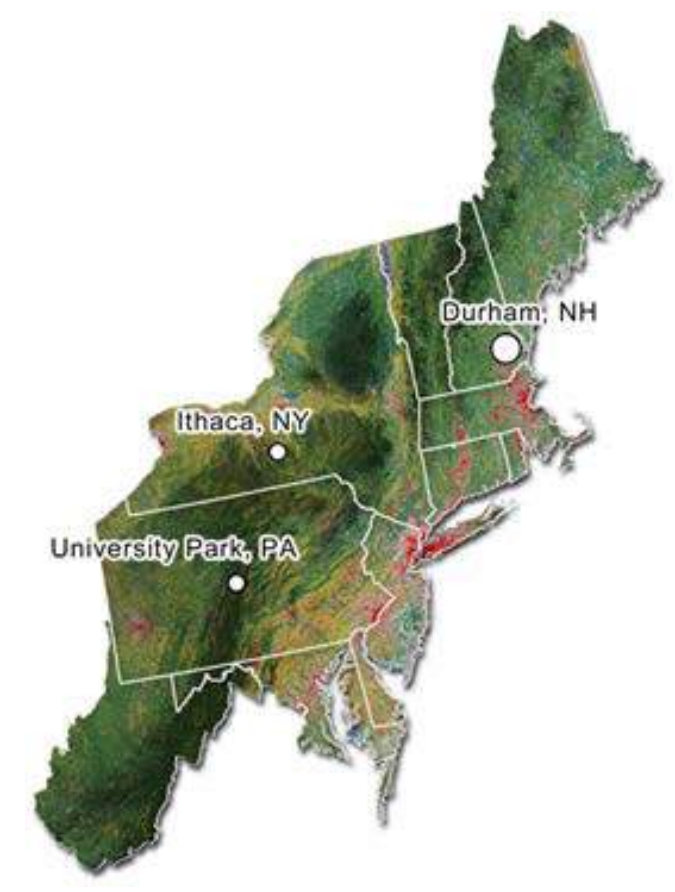

Figure 1: Northeast Hub. Legend: Cultivated (brown), Grassland (tan), Forest (green), Developed (red), Water (blue)

Introduction 


\section{Northeast Region}

\subsection{Demographics and Land Uses}

Across the 12 States of the Northeast, about 21 percent of land is farmland (6 percent of the national total of farmland). Productive forestlands (i.e., timberland) cover 62 percent of the land in the Northeast. The northeastern United States is home to about 175,000 farms (National Agricultural Statistics Service, 2009). The number of farms in the six New England States has increased since 2007, but farm numbers have decreased slightly elsewhere in the region. The average size of a northeastern farm is smaller than the national average and ranges from just over 50 acres in Rhode Island to about 200 acres in Delaware and New York. The Northeast has a much higher percentage of women farmers than nationally, and farmers in the Northeast (Principal Operators) are somewhat younger than the national average (National Agricultural Statistics Service, 2014a).

The most important commodities in the Northeast are dairy production and poultry (split about equally between chicken and eggs). About half of the field crops (including pasture) grown in the Northeast are for animal feed. Milk sales in the Northeast exceeded \$5.4 billion in 2012, whereas combined animal sales (livestock, hogs, and poultry) were almost $\$ 6$ billion. The total value of crops exceeded $\$ 9$ billion with horticulture (including greenhouse plants, nursery, sod, and mushrooms) at $\$ 2.5$ billion a much larger share of the total than in most other regions. Organic production in the Northeast ( $\$ 337$ million in 2012) is also relatively more important than in other regions and is increasing rapidly (up by 50 percent since the previous National Agricultural Statistics Service census in 2007) (National Agricultural Statistics Service, 2014a).

\subsection{General Climate Conditions, Extremes, and Past Effects}

The climate of the Northeast is changing. Weather station data show that between 1895 and 2011, temperatures of the region increased by almost $2^{\circ} \mathrm{F}\left(0.16^{\circ} \mathrm{F}\right.$ per decade $)$, precipitation increased by approximately 5 inches, or more than 10 percent ( 0.4 inches per decade), and growing seasons lengthened by more than a week. These gradual changes are punctuated by more hot days, fewer cold days, and more intense rain. These changes, combined with increases in atmospheric carbon dioxide and atmospheric nitrogen deposition (both of which can act as plant fertilizers) provide more opportunities for farmers and foresters of the region, but also pose significant risks, especially if producers do not adapt to the new conditions. Increased coastal flooding from rising seas levels (approximately 1 foot since 1900), coupled with more intense ocean storm surges, is an additional concern for coastal and estuarine producers.

\subsection{Summary of Regional Climate Trends and Scenario for the Future}

Mark Twain remarked on the "sumptuous variety" of the weather in the northeastern United States that takes form as pronounced seasonality in temperature and extreme weather events ranging from major snow and ice storms to flood-producing rainstorms and hurricanes.

\section{Temperature}

In general, the observed temperature increase in the Northeast mirrors that experienced in other parts of the country except for the Southeast, where the trend in temperature has been less pronounced (Kunkel et al., 2013). Across the region, average annual temperatures range from near $60^{\circ} \mathrm{F}$ in the south to as cold as $35^{\circ} \mathrm{F}$ in Maine. Precipitation ranges from less than 35 inches in parts of New York to more than 60 inches, typically at high-elevation inland sites. On the basis of data from the NOAA Cooperative Observer Network (Kunkel et al., 2013), regional annual and seasonal temperature anomalies ${ }^{1}$ have

\footnotetext{
${ }^{1}$ A temperature anomaly is a departure from a reference value over a long-term average. Positive anomalies demonstrate that the observed temperature was warmer than the reference value, and negative anomalies indicate the observed temperatures were cooler than the reference value (National Oceanic and Atmospheric Administration, 2015).
}

Introduction 
remained above the 1901-1960 average during the last 30 years, with long-term annual and seasonal temperatures trending upward between 0.11 and $0.24^{\circ} \mathrm{F} / \mathrm{decade}$ over this time (Kunkel et al., 2013).

\section{Precipitation}

Precipitation has also increased across the region, although the most noteworthy change in precipitation has been an increase in rainfall intensity (Kunkel et al., 2013). The Northeast and Midwest stand out as experiencing the largest recent increases in annual precipitation in the continental United States (Kunkel et al., 2013), with the largest increase in extreme precipitation events in the northern half of the Northeast. Annual rainfall trends are up 0.39 inches/decade and 0.24 inches/decade in the fall in the Northeast when compared with 1895-2011 trends (see Table 1). There has been a clear shift toward greater variability and higher totals since 1970 (see Figure 2) (Kunkel et al., 2013).

\section{Growing Season}

The length of the freeze-free season has increased by about 10 days (Kunkel et al., 2013).

Responding to these changes, farmers in the Northeast are already adopting new practices that were not possible or necessary a few decades ago, including double cropping and strategically planting new orchards on hilltops where they are less at risk due to unseasonal frost.

\section{Expected Changes}

Based on recent projections (Kunkel et al., 2013), these regional trends are expected to continue through 2100. By the end of the century, temperatures may increase by as much as $8.5^{\circ} \mathrm{F}^{2}$ (relative to the $1971-2000$ base period) with warming greatest in the winter (Kunkel et al., 2013). Precipitation in the Northeast is also projected to continue to increase with an average of $5 \%$ to $10 \%$ more by the end of the century (Kunkel et al., 2013). Commensurate changes in extreme heat, growing season length, and extreme rainfall are also anticipated.
Table 1: 1895-2011 trends in temperature anomaly ( ${ }^{\circ} \mathrm{F} /$ decade) and precipitation anomaly (inches/decade) for each season as well as the year as a whole.

\begin{tabular}{|c|c|c|}
\hline Season & $\begin{array}{l}\text { Temperature } \\
\text { ( }{ }^{\circ} \text { F/decade) }\end{array}$ & $\begin{array}{l}\text { Precipitation } \\
\text { (inches/decade) }^{\mathrm{a}}\end{array}$ \\
\hline Winter & +0.24 & NS \\
\hline Spring & +0.14 & NS \\
\hline Summer & +0.11 & NS \\
\hline Fall & +0.12 & +0.24 \\
\hline Annual & +0.16 & +0.39 \\
\hline \multicolumn{3}{|c|}{$\begin{array}{l}\text { a NS=Not Significant. Only values statistically } \\
\text { significant at the } 95 \% \text { confidence level are displayed. }\end{array}$} \\
\hline \multicolumn{3}{|c|}{$\begin{array}{l}\text { Source: Kunkel (2013) based on a new gridded } \\
\text { version of COOP data from the National Climatic } \\
\text { Data Center, the CDDv2 data set for the northeastern } \\
\text { United States. }\end{array}$} \\
\hline
\end{tabular}

Difference in Mean Annual Precipitation for the Northeast U.S. (Deviations from the 1901-1960 Average)

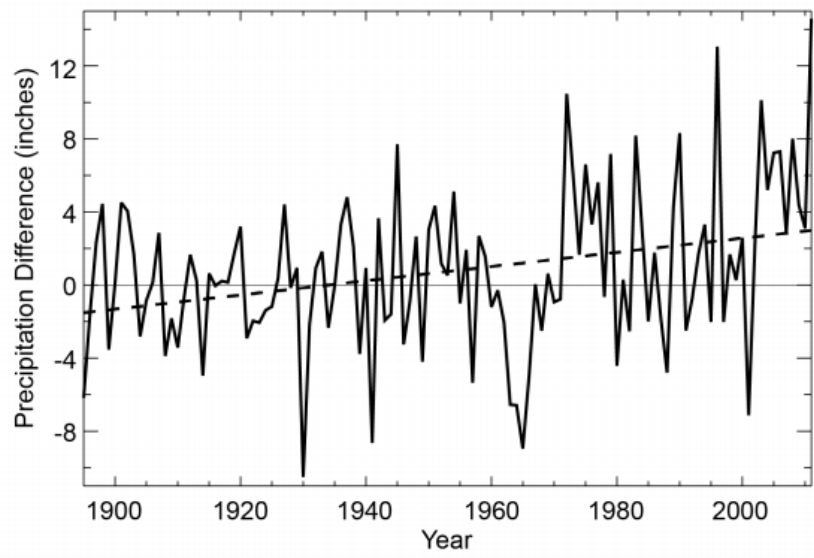

Figure 2: Difference in Mean Annual Precipitation for the Northeast U.S. (Deviations from the 1901-1960 Average) (Kunkel et al.. 2013). 


\section{General Climate Effects on Agriculture and Forests}

It is expected that the Northeast region will experience a variety of effects as the climate changes. From longer growing seasons to increases in extreme precipitation, land managers will find themselves having to manager their lands in an increasingly variable climate. By building resilience through a greater understanding of what is expected in the future, adopting adaptation strategies and using the latest technologies to help make climate-informed decisions, working land managers can better manage risk in an increasingly uncertain environment.

\section{Longer Growing Seasons}

Growing seasons have already lengthened across the Northeast during the last several decades, and there is strong agreement that this trend will continue (Horton et al., 2014; Kunkel et al., 2013). Longer growing seasons have altered the timing of agricultural, ecosystem, and physiological processes across the region, including leaf emergence and duration, bird migration, and lake ice duration (Rustad et al., 2012). Earlier springs and longer growing seasons will continue to allow the use of new and later season varieties, and cause shifts in phenology of species that rely on temperature as a cue for the timing of leafout, reproductive maturation, and other developmental processes (Schwartz et al., 2006; Walther et al., 2002). Longer growing seasons will likely result in greater growth and productivity of crops, forests, and other vegetation, but only if balanced by available water and nutrients.

\section{Shorter, Warmer Winter}

Warmer winter temperatures are likely to cause changes in numerous winter processes. Snowfall and snowpack are expected to decrease and the region is projected to experience fewer days of soil frost by the end of the century (Hayhoe et al., 2007; Notaro et al., 2014). Although these conditions could increase water infiltration into the soil and reduce runoff, they may also lead to greater soil water losses through increased evapotranspiration. This decrease in snow cover and frozen soil may affect a variety of agricultural and ecosystem processes, including decomposition, nutrient cycling, and the onset of the growing season (Rustad et al., 2012). Over the past several decades, the duration of lake ice has decreased and peak stream flows have shifted to earlier in the season (Hodgkins et al., 2003; Hodgkins \& Dudley, 2005; Hodgkins et al., 2002). Furthermore, altered seasonality in northern areas may lead to reduced winter operations for forest management activities (Rittenhouse \& Rissman, 2015) and result in increases in pests and disease, and the spread of nonnative invasive species.

\section{More Extreme Precipitation}

The Northeast region has experienced a greater than 70 percent increase in extreme precipitation events since the mid-1900s, the most of any region in the United States, and this increase is expected to continue (Hayhoe et al., 2007; Kunkel et al., 2013; Melillo et al., 2014). Projected increases in heavy precipitation combined with milder winters is expected to increase total runoff and peak stream flow during the winter and spring (Hayhoe et al., 2007), which may increase the magnitude or frequency of flooding. Increases in runoff following heavy precipitation will also likely lead to an increase in soil erosion (Nearing et al., 2004). The risk to farms and forests from flooding, erosion and other effects will ultimately depend on local geological and topographic conditions and interactions with management, infrastructure, and land use.

\section{Changes in Soil Moisture and Drought}

Given recent warmer trends in temperatures and seasonal changes in precipitation that are expected to continue across the region, it is reasonable to expect that soil moisture will also shift. Longer growing seasons and warmer temperatures result in greater evapotranspiration losses and lower soil-water availability later in the growing season (Gutowski et al., 2008; Hayhoe et al., 2007), thereby increasing 


\section{Northeast Region}

moisture stress on plants. Furthermore, increases in extreme rain suggest that greater amounts of precipitation may occur during fewer precipitation events, resulting in longer periods between rainfall (Karl et al., 2008). At the same time, there is substantial variation among model projections of growing season precipitation (Hayhoe et al., 2007; Kunkel et al., 2013), which increases uncertainty regarding the potential for increases in precipitation sufficient to offset increases in evapotranspiration.

\section{Enhanced Fire Risk}

At a global scale, the scientific consensus is that wildfire risk will increase by 10 to 30 percent due to higher summer temperatures (Intergovernmental Panel on Climate Change, 2007). There is low agreement in this trend across climate models for the early part of the 21st century (Moritz et al., 2012). By the end of the century, however, most national models project an increase in wildfire probability, particularly for boreal forests, temperate coniferous forests, and temperate broadleaf forests. Recent modeling relevant to the Northeast suggests that increases in wildfire risk may be greatest in the southern portion of the region, particularly in western Pennsylvania and West Virginia (Tang et al., 2015). In addition to the direct effects of temperature and precipitation, increases in forest fuel loads from pestinduced mortality or blowdown events could increase fire risk, but the relationship between these factors can be complex (Hicke et al., 2012). Forest fragmentation and wildfire management also make fire projections more uncertain for the region.

\section{Intensified Biological Stressors}

Changes in climate may allow some nonnative plant species, insect pests, and pathogens to expand their ranges farther north (Dukes et al., 2009; Rustad et al., 2012; Weed et al., 2013) as the climate warms and the region loses some of the protection offered by a traditionally cold climate and short growing season. The abundance and distribution of some nonnative plant species may be able to increase both directly in response to a warmer climate and also indirectly through increased invasion of stressed crops or forests (Ryan \& Vose, 2012). Similarly, forest pests and pathogens are generally able to rapidly respond to changes in climate and also disproportionately damage stressed ecosystems (Weed et al., 2013). Thus there is high potential for pests and pathogens to interact with other climate-mediated stressors. Unfortunately, we lack basic information on the climatic thresholds that apply to many invasive plants, insect pests, and pathogens. Furthermore, there remains a limited ability to predict the mechanisms of infection (in the case of pests and diseases), dispersal, and spread for specific agents, as well as which specific nonnative species, pests, or pathogens may enter the region during the 21 st century.

\section{Regional Agriculture's Sensitivity to Climate Change and Adaptation Strategies}

In the Northeast, various cropping systems and livestock systems are sensitive to climate variability. This section provides an overview of these two sector's vulnerabilities as well as adaptation strategies to help land managers build resilience.

\subsection{Cropping Systems}

Cropping systems in the Northeast are marked by diversity. Field crops, tree fruits, vegetables, berries and vine fruits, and specialty products such as mushrooms and ornamentals are all important components of agricultural output in the Northeast. Given the variability in weather common to the region, farming systems will be affected in various ways by climate change. This section considers important elements of crop production to the Northeast, focusing on particular vulnerabilities to specific cropping systems, potential opportunities to each, as well as adaptation strategies.

\section{Field Crops}

Regional Agriculture's Sensitivity to Climate Change and Adaptation Strategies

Page $\mid 10$ 


\section{Northeast Region}

Field crops and pasture are important to agricultural production in the Northeast. These crops, which include corn, soybean, small grains (wheat, oats, etc.), hay crops, and pasture mixes, are among the top five most important agricultural commodities in Delaware, Maryland, New Hampshire, New Jersey, New York, Pennsylvania, and Vermont (National Agricultural Statistics Service, 2014b). In Delaware, corn for grain and soybean occupy 43 percent and 36 percent of cropland, respectively, and generate about $\$ 130$ million or roughly 12 percent of total agricultural sales (Division of Energy and Climate, 2014). In both Delaware and Maryland, field corn and soybean crops are often sold within State to poultry farmers (Coale et al., 2011; Division of Energy and Climate, 2014). In States where the cattle industry is important, many farmers produce hay and corn and maintain pastureland (Nash \& Galford, 2014; Wolfe et al., 2011). For example, field corn in Pennsylvania is primarily grown as grain, although about onethird is harvested as silage to provide forage for dairy and beef cattle (Union of Concerned Scientists, 2008).

Rising summer temperatures and related heat stress may have serious consequences for field crops. Under high emissions scenarios, daytime temperatures are expected to rise throughout the region and will likely be felt acutely in the southern region of the Northeast, where temperatures are expected to frequently surpass $90^{\circ} \mathrm{F}$ during summer months by mid-century under higher greenhouse gas emission scenarios (Horton et al., 2014). These high temperatures can hamper pollination of corn and other crops, and reduce productivity and quality of grains such as corn, wheat, and oats (Division of Energy and Climate, 2014; Nash \& Galford, 2014; New Jersey Climate Adaptation Alliance, 2014b; Union of Concerned Scientists, 2008). Although greater atmospheric carbon dioxide concentrations are expected to increase small grain production, the benefits will not likely offset the harm caused by heat stress (Coale et al., 2011; Division of Energy and Climate, 2014). Furthermore, rising temperatures are linked with the production of ozone, a pollutant that may lower crop production. Soybeans and wheat have been shown to be particularly susceptible to ozone (Division of Energy and Climate, 2014).

Climate projections also suggest that drought conditions are expected to occur more frequently during the summer (Wolfe et al., 2011). This could result in lower crop yields and increased reliance on irrigation. In States such as Connecticut, New York, and Vermont, this may pose a problem for field crop farmers because grain crops do not generate sufficient return to merit investments in irrigation (Adaptation Subcommittee to the Governor's Steering Committee on climate change, 2010; Nash \& Galford, 2014; Wolfe et al., 2011). Current irrigation systems are primarily dedicated to high-value horticultural crops. Drought also diminishes the productivity and quality of pastureland, which is a concern for farmers who graze their cattle (Coale et al., 2011). Heavy precipitation can also damage grain and forage crops. Heavy precipitation can delay planting and harvesting (Division of Energy and Climate, 2014; Horton et al., 2014). Not only does water inundation of fields increase the likelihood of disease, but use of heavy machinery in flooded fields can cause soil compaction, thereby damaging soil quality (Division of Energy and Climate, 2014; Nash \& Galford, 2014; Wolfe et al., 2011). Due to rising winter temperatures, the possibility of winter flooding also increases, threatening the viability of winter cover crops such as winter wheat (Coale et al., 2011).

Pests and pathogen pressures are expected to rise due to climate variability, also posing a threat to field crops. Soybean rust, for example, can decimate harvests; although not yet considered an immediate danger to the region, the likelihood that this pathogen will move north from southern States increases as temperatures warm (Coale et al., 2011; Division of Energy and Climate, 2014). Rising winter temperatures and increased atmospheric carbon dioxide will also likely intensify existing pest and pathogen outbreaks over a larger part of the growing season and stimulate migration of invasive weeds and pests from other regions of the country (Division of Energy and Climate, 2014; Union of Concerned Scientists, 2008; Wolfe et al., 2011). 
Possible adaptation strategies to the climate vulnerabilities related to field crops and pasture include expanding water containment and storage systems and irrigation capacity for conditions of too little water, and drainage systems for too much water (Coale et al., 2011; Division of Energy and Climate, 2014). However, analyses must be conducted to consider the costs and benefits of investing in irrigation infrastructure for these types of crops and the stresses on water resources that could result (Adaptation Subcommittee to the Governor's Steering Committee on climate change, 2010; Nash \& Galford, 2014; Wolfe et al., 2011). Investigating the potential for different kinds of crops and varieties, and identifying and disseminating best management practices may also help farmers avoid problems with winter flooding, pressure from pests and pathogens, and soil degradation (Coale et al., 2011; Wolfe et al., 2011). To further aid farmers in their efforts to manage pests, forecasting must be improved (Coale et al., 2011). Shifting planting dates may also help farmers avoid the most severe effects of extreme weather events, though determining optimal dates is difficult (Wolfe et al., 2011). Farmers who shift planting dates of cool-season grains may buffer against potential losses in yield due to warmer winters (Griffin, 2009).

Climate change may also provide opportunities for farmers who grow field crops and manage pastures. For example, if invasive weeds can be managed, small grain and hay crops may benefit from increased atmospheric carbon dioxide (Division of Energy and Climate, 2014). With warmer temperatures and extended growing seasons, opportunities for expanded production of grain crops in northern States may exist (Adaptation Subcommittee to the Governor's Steering Committee on climate change, 2010; Griffin, 2009). Connecticut has identified potential in growing biofuel crops such as switchgrass and corn (Adaptation Subcommittee to the Governor's Steering Committee on climate change, 2010). Biofuel crops, however, must be considered carefully; although they may help reduce fossil fuel consumption (Adaptation Subcommittee to the Governor's Steering Committee on climate change, 2010), they may also contribute to higher prices for feed grain should they replace field crops grown for livestock feed (Wolfe et al., 2011). A

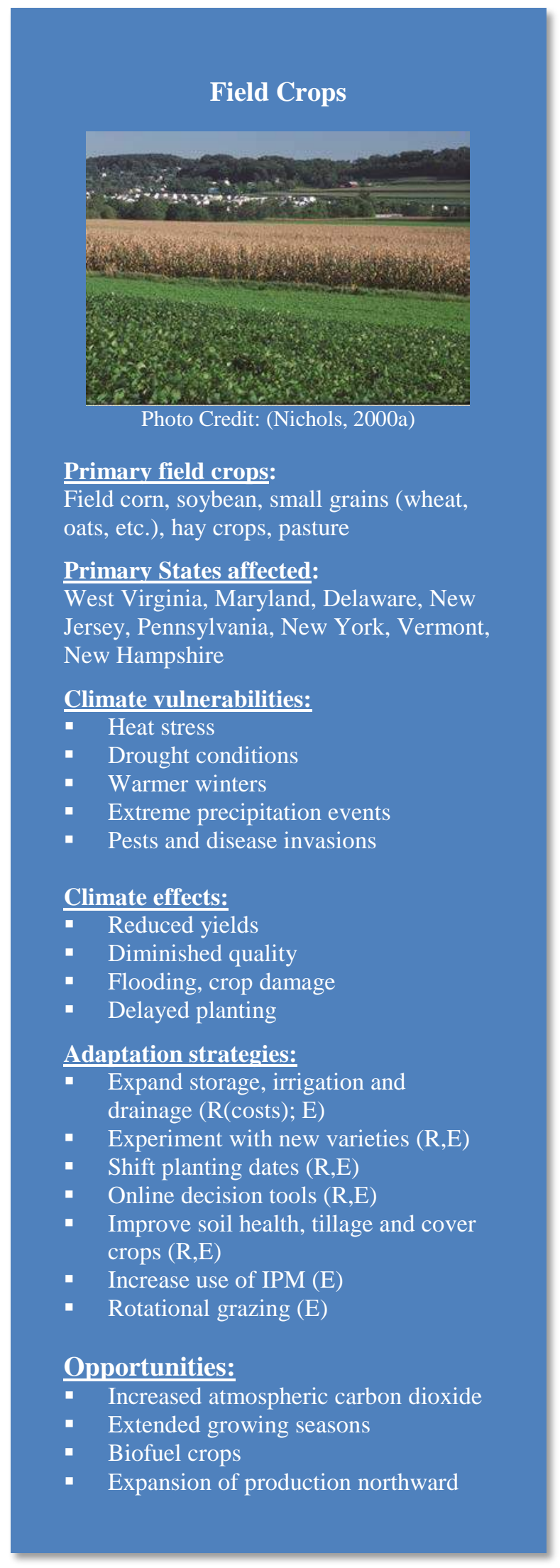




\section{Northeast Region}

synopsis of the climate challenges, adaptation strategies, ${ }^{3}$ and opportunities for field crops and pasture, is presented in the adjacent text box.

\section{Tree Fruits}

Tree fruits figure prominently in agricultural production in the Northeast, especially in the southern part of the region. New York, for example, was ranked second in apple production nationally in 2012 with a production value at about $\$ 250$ million, whereas Pennsylvania was the third-largest national producer of apples, with about $\$ 133.5$ million in production value. In addition to both of these States, Connecticut, Maine, Maryland, Massachusetts, New Hampshire, Vermont, and West Virginia were all among the top 25 States in terms of apple production value in 2012 (National Agricultural Statistics Service, 2014a). Nationally, New Jersey and Pennsylvania are ranked fourth and fifth, respectively, for peach production, whereas Connecticut is the leading producer of peaches among New England States and is a top-ten producer nationally of pears (Adaptation Subcommittee to the Governor's Steering Committee on climate change, 2010). Given its strength in tree fruit production, Connecticut has identified apples and pears as among its five most vulnerable agricultural products to climate change (Adaptation Subcommittee to the Governor's Steering Committee on climate change, 2010).

Climate threats to tree fruits relate to temperature, precipitation, and pest and disease pressures. For apple production in New York and Pennsylvania, expected warmer winters may mean that popular apple varieties in each State (such as McIntosh and Granny Smith in Pennsylvania, and McIntosh and Empire in New York) no longer receive sufficient winter chill hours for commercial viability by mid-century, especially under higher greenhouse gas emissions scenarios (Union of Concerned Scientists, 2008; Wolfe et al., 2011). In recent years, warmer winters have spurred earlier bloom of apple trees, which then increases vulnerability to frost damage if temperatures drop below freezing again in the spring (Horton et al., 2014; Wolfe et al., 2011) as occurred across New England in 2012. Empirical evidence has also shown that warmer winters can reduce apple yield the following summer, as can summer heat during periods of fruit set (Wolfe et al., 2011). In addition to temperature, changes in the type, amount, and distribution of precipitation may also effect tree fruit production (Nash \& Galford, 2014). Connecticut farmers, for example, have reported that hail damage to tree fruits such as peaches, nectarines, and plums have reduced yields (Adaptation Subcommittee to the Governor's Steering Committee on climate change, 2010). More frequent extreme weather events are also likely to make tree fruits more susceptible to fungal infections such as apple scab (Adaptation Subcommittee to the Governor's Steering Committee on climate change, 2010; Nash \& Galford, 2014).

Possible adaptation strategies include changing varieties of fruit trees or changing to new species of fruit trees altogether. As growing seasons will continue to extend, longer-season varieties could be an option for growers in States such as New York and Pennsylvania. Although similar strategies were not explicitly discussed in other State reports, this strategy might be applicable to other Northeast states as well, such as Vermont, which recognized that some apple varieties may not be viable in southern parts of the State due to winter warming (Nash \& Galford, 2014). If this strategy is selected, farmers could experiment with new varieties as they transition out of those that are currently popular in their States but require long winter chill hours. For example, although McIntosh and Empire apples may become more difficult to grow in New York, opportunities could expand for Fuji and Granny Smith. Granny Smith is currently popular in Pennsylvania but may lose its commercial feasibility in this State by late century under both low and high greenhouse gas emissions scenarios (Union of Concerned Scientists, 2008; Wolfe et al., 2011). Decision-making might also be aided by tools that track weather and pest threats such as those currently available at Cornell University's Network for Environment and Weather Applications (NEWA).

\footnotetext{
${ }^{3}$ Within the adaptation strategies section, Research (R) and/or Extension (E) is noted to indicate which of these functions will be necessary to provide assistance to farmers to adapt.
}

Regional Agriculture's Sensitivity to Climate Change and Adaptation Strategies

Page | 13 
The tools available at NEWA promote Integrated Pest Management, another adaptation strategy that can help tree fruit growers with the threat of intensified pest invasions. Expanding irrigation capacity provides another possible adaptation strategy for tree fruits such as peaches and pears, helping to protect these sensitive species from heat stress and more frequent summer droughts (Adaptation Subcommittee to the Governor's Steering Committee on climate change, 2010; New Jersey Climate Adaptation Alliance, 2014b). However, increases in operational costs related to irrigation must be considered (New Jersey Climate Adaptation Alliance, 2014b). Other adaptation strategies include shifting production away from flood- and frost-prone areas and using helicopters or wind machines to mix the air and keep stratified cold pockets from developing to protect their tree fruits from frost after early bud bloom (Perry, 1998; Snyder \& Melo-Abreu, 2005).

Although several current fruit tree varieties may be threatened by climate change, opportunities for the region do exist. Longer and warmer growing seasons and increased atmospheric carbon dioxide will likely benefit production potential for apples and pears (Adaptation Subcommittee to the Governor's Steering Committee on climate change, 2010; Wolfe et al., 2011). Warmer temperatures also mean long frost-free periods, benefitting crops such as peaches and apple varieties that produce best with long growing seasons (New Jersey Climate Adaptation Alliance, 2014b; Wolfe et al., 2011). Longer growing seasons and higher minimum winter temperatures might also allow northern States (e.g., Vermont) to expand commercial production of crops such as peaches (Nash \& Galford, 2014).

The text box presents a summary of climate change considerations related to tree fruits in the Northeast including the primary fruits and States effected the climate vulnerabilities and effects projected to occur, possible adaptation strategies, and the potential opportunities to emerge.

\section{Vegetables}

The Northeast is renowned for its extensive vegetable production. Key crops include tomatoes, sweet corn, cucurbits, brassicas, melons, potatoes, and sweet potatoes. In terms of the market value for agricultural products sold in each State, vegetables were among the top five crop commodities in 2012 in Connecticut,

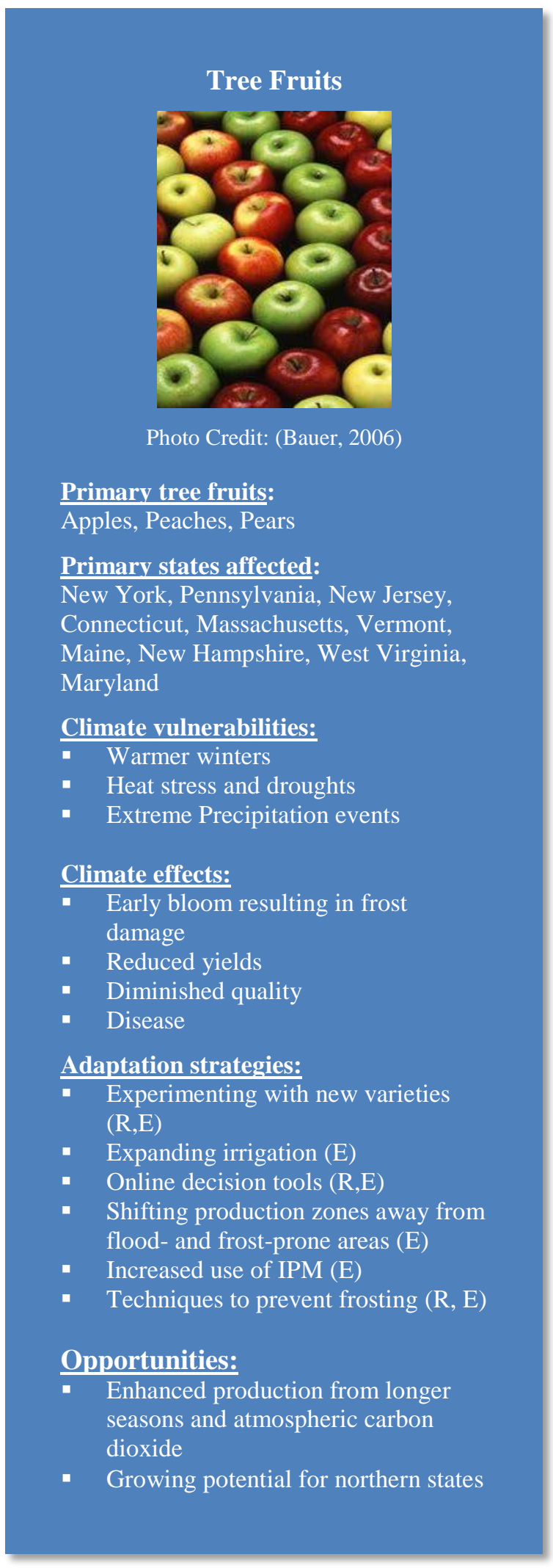




\section{Northeast Region}

Delaware, Maine, Maryland, Massachusetts, New Hampshire, New Jersey, New York, and Rhode Island (National Agricultural Statistics Service, 2014c). The vegetable industry generated about $\$ 364$ million in New York in 2012 (National Agricultural Statistics Service, 2014c), whereas cash receipts for vegetables in Vermont totaled about $\$ 13$ million and constituted the fourth most valuable commodity in the State (Nash \& Galford, 2014). New Jersey ranks in the top 10 States nationally for the production of tomatoes, bell peppers, snap beans, cucumbers, spinach, and squash (New Jersey Climate Adaptation Alliance, 2014b), whereas potato acreage in Maine ranks fifth nationally (National Agricultural Statistics Service, 2014d). Connecticut leads New England in production of tomatoes, green beans, and asparagus (Adaptation Subcommittee to the Governor's Steering Committee on climate change, 2010). Sweet corn, often considered a high-value horticultural crop, is also important regionally, especially in the southern portion of the Northeast. It is a major vegetable crop in Delaware, is grown in every county in Pennsylvania, and is produced in New York at such a scale that the State is typically a top-five producer of fresh-market sweet corn nationally (Division of Energy and Climate, 2014; Union of Concerned Scientists, 2008; Wolfe et al., 2011).

The climate vulnerabilities affecting vegetable production relate to precipitation, temperature, and pest pressures. Variability in precipitation has serious implications for vegetables given that water is among the most important determinants of yield (Division of Energy and Climate, 2014). As drought conditions are expected to increase during summer months in the Northeast (Union of Concerned Scientists, 2008), water stress will likely present difficulties for vegetable producers (Coale et al., 2011; Division of Energy and Climate, 2014). For example, although many vegetable producers in New York have irrigation infrastructure available, few have the capacity to contend with extended drought conditions (Wolfe et al., 2011). Likewise, New Jersey farmers have expressed concern that inadequate irrigation will negatively affect their production (New Jersey Climate Adaptation Alliance, 2014a). Excessive rainfall is also problematic for growers because extreme precipitation events can reduce yields, lead to flooding and delay springtime planting (Adaptation Subcommittee to the Governor's Steering Committee on climate change, 2010; Nash \& Galford, 2014; Union of Concerned Scientists, 2008). As a result of delayed springtime planting due to heavy rainfall in 2011, shortages of vegetables and late harvests occurred in New York (Friedline, 2011).

Although warmer summer temperatures will extend growing seasons and may be beneficial to crops that thrive in heat such as melons, okra, and sweet potatoes, other crops that grow best in cooler conditions such as potatoes, lettuce, and brassicas, will likely suffer (Griffin, 2009; New Jersey Climate Adaptation Alliance, 2014b; Union of Concerned Scientists, 2008). Furthermore, heat stress during critical periods of development can damage crops such as tomatoes and sweet corn (Division of Energy and Climate, 2014; Union of Concerned Scientists, 2008). Warmer temperatures coupled with increased atmospheric carbon dioxide also greatly benefit weeds in comparison to crops (Horton et al., 2014; Wolfe et al., 2011). Kudzu, an aggressive weed prominent in the south, has already appeared in Pennsylvania (Union of Concerned Scientists, 2008), whereas Palmer amaranth, a relative to pigweed found in the south and southwestern United States, has recently entered Delaware (Division of Energy and Climate, 2014). Sweet corn is expected to become increasingly vulnerable to Stewart's Wilt, a bacterial disease carried by flea beetles, and to corn earworms (Union of Concerned Scientists, 2008; Wolfe et al., 2011). Maine is preparing to contend with intensified pressure from Colorado potato beetles (Griffin, 2009), and the increased moisture from extreme precipitation events may lead to more frequent outbreaks of potato and tomato blight (Nash \& Galford, 2014). Warmer temperatures are also associated with higher levels of ozone (Wolfe et al., 2011), which can cause crop damage, especially in vegetable crops such as lettuce, potato, spinach, tomato, watermelon, cantaloupe, snap bean, pumpkin, and squash (Division of Energy and Climate, 2014). 
Given the concerns related to more frequent drought conditions during the growing season, expanded irrigation capacity is an adaptation strategy already being implemented by vegetable producers (Division of Energy and Climate, 2014; Wolfe et al., 2011). To minimize pressure on water resources, precise irrigation methods such as drip irrigation may be worthwhile to consider (Adaptation Subcommittee to the Governor's Steering Committee on climate change, 2010; Coale et al., 2011; Division of Energy and Climate, 2014). Production of warm-weather crops can likely be expanded as growing seasons extend (Griffin, 2009; Nash \& Galford, 2014). The climate in Maine, for example, makes current production of corn difficult, but changing conditions may make it more viable (Griffin, 2009). Farmers could shift to crops that produce best with longer growing seasons such as watermelon, tomato, pepper, and cantaloupe (Division of Energy and Climate, 2014; Executive Office of Energy and Environmental Affairs, 2011; Union of Concerned Scientists, 2008; Wolfe et al., 2011).

Breeding programs may also be beneficial in developing new cultivars that are more tolerant to the climate hazards projected to occur in the region (Division of Energy and Climate, 2014; Wolfe et al., 2011). However, this may be a difficult task. For example, varieties of sweet corn have been bred to resist Stewart's Wilt, but neither their taste, texture, nor appearance is acceptable to market preferences (Wolfe et al., 2011). Shifting planting dates presents another option that vegetable farmers might consider to cope with heat, water stress, and extreme rainfall, although ideal planting dates are difficult to predict (Wolfe et al., 2011). In addition, delayed springtime planting may result in farmers losing premiums for early season harvests (Nash \& Galford, 2014). To aid farmers in decision-making, online tools that forecast both extreme weather and pest and disease invasions will likely be useful (Coale et al., 2011; Executive Office of Energy and Environmental Affairs, 2011; Nash \& Galford, 2014; Wolfe et al., 2011). If pests can be managed, increased atmospheric carbon dioxide can also benefit crop production (Wolfe et al., 2011). Implementing Integrated Pest Management strategies may help farmers manage intensified pest pressures (Wolfe et al., 2011). Use of hoop houses and high tunnels is one strategy that is already helping vegetable farmers contend with extreme weather and pest invasions (Nash \& Galford, 2014).

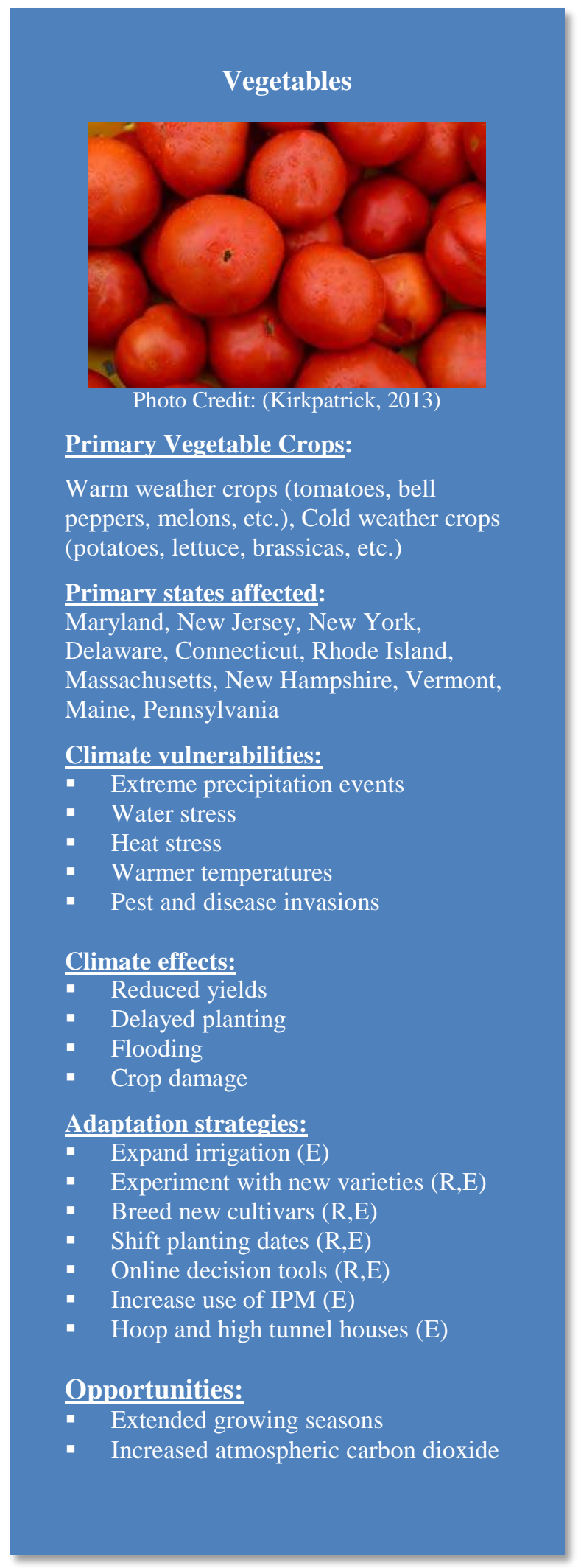




\section{Northeast Region}

\section{Berries and Vine Fruits}

Berries and vine fruits are important agricultural commodities in different regions of the Northeast. Both New York and Pennsylvania are among the top five national producers of grapes, particularly Concord grapes used for grape juice (Union of Concerned Scientists, 2008; Wolfe et al., 2011). In Pennsylvania, Concord grape production is concentrated in Erie County, with employment of about 1,000 people and an annual economic value of more than $\$ 180$ million (Union of Concerned Scientists, 2008). Elsewhere in the region, berries are an important economic crop. New Jersey and New York are among the top five States in blueberry production value. The value of cranberry production for Massachusetts and New Jersey is also in the top five (National Agricultural Statistics Service, 2014c). Cranberries represent the largest revenue-generating crop in Massachusetts (Executive Office of Energy and Environmental Affairs, 2011). The importance of berries extends northward as well; wild blueberries are, for example, both a major economic product of Maine, as well as iconic species for the State (Griffin, 2009).

Climate changes will have varying effects on berries and vine fruits in the Northeast. The grapes currently grown in New York and Pennsylvania need substantial winter chilling hours, and warmer winter temperatures may threaten their viability. Under high greenhouse gas emissions scenarios, winter chilling requirements would likely only be met for one out of every two winters by mid-century in Pennsylvania (Union of Concerned Scientists, 2008). In New York, grapes suffered freeze damage after their vines de-hardened due to unusually warm Decembers in 2003 and 2004 (Horton et al., 2014). Frosts in the late winter or early spring after a warmer winter can damage grape crops if early bloom occurs, which happened in both 2007 and 2012 (Horton et al., 2014).

Warming temperatures also jeopardize cranberry, blueberry, and raspberry production in the Northeast, as winter chilling requirements may not

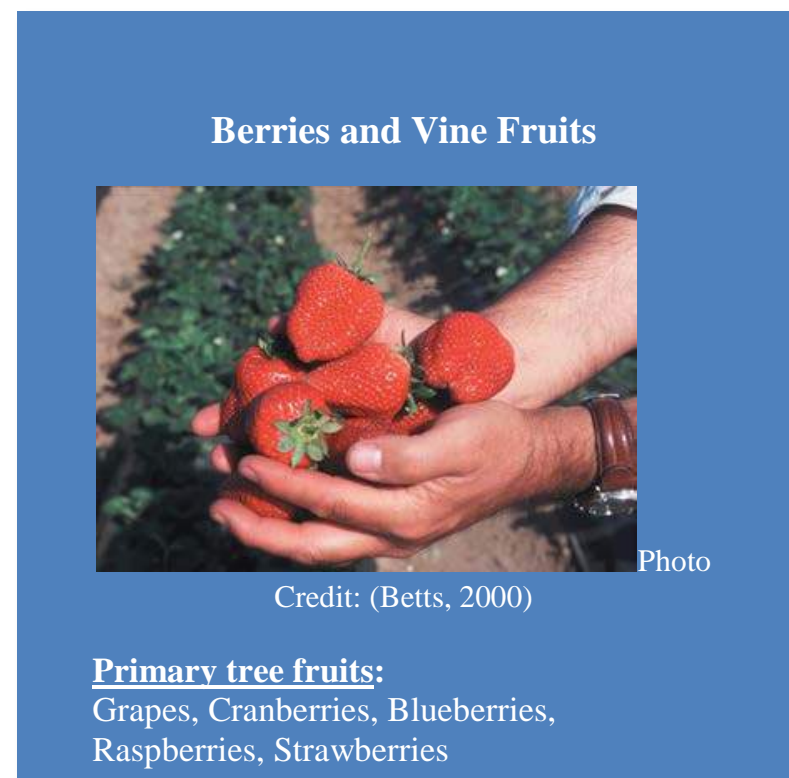

Primary states affected:

New York, Pennsylvania, New Jersey,

Connecticut, Massachusetts, Maine, Rhode Island

Climate vulnerabilities:

Warmer winters

- Pest invasions

- Heat stress and drought

\section{Climate effects:}

- Dehardened vines resulting in frost damage

- Early bloom resulting in frost damage

- Reduced yields

\section{Adaptation strategies:}

Experimenting with new varieties (R,E)

- Modified greenhouse approaches and high tunnels (E)

- Expanding irrigation (E)

- Online decision tools (R,E)

- Increased use of IPM (E)

\section{Opportunities:}

- Wine grapes

- Growing potential for northern states be met by mid-century under higher greenhouse gas emissions scenarios in States such as Rhode Island (Roberts et al., 2010). Warming temperatures will likely be accompanied by intensified pest invasions. Already a problem in Pennsylvania, the grape berry moth is expected to cause more damage to grape production (Union of Concerned Scientists, 2008). Griffin (2009) noted that the wild blueberries of Maine are already experiencing the effects of invasions 


\section{Northeast Region}

by the blueberry gall midge. The invasive spotted winged Drosophila, which attacks all soft fruits, has also been reported in all fruit-producing regions of the United States and has the ability to overwinter as winter temperatures increase with climate change (Lee et al., 2011).

Despite existing vulnerabilities to climate change, berry production is more adaptable than other important crops in the Northeast (Adaptation Subcommittee to the Governor's Steering Committee on climate change, 2010). Therefore, Connecticut has characterized the risk to its berry and grape production as low, adding nuance by explaining that raspberries and blueberries are less threatened by climate change than strawberries (Adaptation Subcommittee to the Governor's Steering Committee on climate change, 2010). Possible adaptation strategies for grape and berry growers include modified greenhouses and high tunnels to prevent damage from weather events and pests, as well as installing drip irrigation (Adaptation Subcommittee to the Governor's Steering Committee on climate change, 2010). In New York, farmers have reported using both high tunnels and expanded irrigation to adapt to changing conditions (Cornell Horticulture, 2014). As pest invasions intensify, Integrated Pest Management may provide an important technique to adapt (Regional IPM Centers, 2013; Trumble \& Butler, 2009). Cranberry farmers in Massachusetts are anticipating warmer temperatures and so are experimenting with the bog management practices used by New Jersey growers (Executive Office of Energy and Environmental Affairs, 2011). New Jersey researchers are monitoring temperatures and experimenting with new cranberry varieties (New Jersey Climate Adaptation Alliance, 2014b), whereas an online decision tool is available to New Yorkers interested in analyzing vineyard sites according to geospatial and climate data. For the grape industries in New York and Pennsylvania, adaptation may mean changing varieties from those that currently require long winter chilling hours to ones that thrive during longer growing seasons (Union of Concerned Scientists, 2008; Wolfe et al., 2011). However, the economic costs of changing varieties are substantial: the Pennsylvania State assessment estimated that replacing one grape variety for another costs $\$ 2,500$ per acre, an expense that may be compounded by the 4 years that grape vines need before they reach maximum production capacity (Union of Concerned Scientists, 2008). In addition, heat stress and summer droughts will likely require expanded irrigation for vineyards (Adaptation Subcommittee to the Governor's Steering Committee on climate change, 2010).

Despite these vulnerabilities, opportunities exist in the Northeast, particularly for grape production. Wolfe et al. (2011) noted that the quantity and quality of red wine grape varieties that are grown in New York will benefit from warmer temperatures. In general, opportunities for expanding to new wine varieties exist in New York and Pennsylvania. These wine varieties provide a potentially lucrative opportunity, considering that many of the most prominent national and global regions for wine grapes will likely suffer substantially from climate changes (Wolfe et al., 2011). As wine grapes become more frequently grown in the region, the expected higher temperatures in winter and drier conditions during summer should enhance grape quality (Adaptation Subcommittee to the Governor's Steering Committee on climate change, 2010). Potential to expand grape production to other northern States is also possible, noted by Nash and Galford (2014), who anticipate opportunities to emerge in Vermont.

\section{Greenhouse, Nursery, Sod, and Specialty Products}

The production of nursery, greenhouse, sod, and other specialty products is particularly important to agricultural sectors in the majority of northeastern States (Connecticut, Delaware, Maine, Maryland, Massachusetts, New Hampshire, New Jersey, New York, Rhode Island, and Vermont) (National Agricultural Statistics Service, 2014c). In fact, this category, sometimes referred to as the green industry (Division of Energy and Climate, 2014), constitutes the most important agricultural commodity in terms of sales in Connecticut, Massachusetts, New Jersey, and Rhode Island(National Agricultural Statistics Service, 2014c). Cash receipts in 2012 totaled nearly \$945 million in Pennsylvania, more than $\$ 400$ million in New Jersey and New York, and more than \$200 million in Connecticut and Maryland (National Agricultural Statistics Service, 2014c). Pennsylvania is the Nation's largest mushroom producer, 
producing about one-third and two-thirds of the country's fresh and processed mushrooms, respectively (Union of Concerned Scientists, 2008).

Of the major agricultural production systems in the Northeast, greenhouse production is arguably the least vulnerable to climate change, given that plants are produced indoors in climate-controlled environments (Adaptation Subcommittee to the Governor's Steering Committee on climate change, 2010). Still, some vulnerabilities do exist, particularly related to the consequences of warming summer temperatures, which may cause higher energy costs if cooling is necessary (Adaptation Subcommittee to the Governor's Steering Committee on climate change, 2010; Coale et al., 2011). Mushrooms, for example, must be produced in a closely regulated, cool climate (Union of Concerned Scientists, 2008). Greenhouse products may also be susceptible to disease and pest outbreaks that will likely become more common as winter temperatures increase (Adaptation Subcommittee to the Governor's Steering Committee on climate change, 2010). For both greenhouse production and outdoor production of sod and nursery products, warmer summer temperatures may increase the need for irrigation to alleviate water stress (Adaptation Subcommittee to the Governor's Steering Committee on climate change, 2010; Coale et al., 2011). On the other hand, events of extreme precipitation, already occurring in the Northeast (Horton et al., 2014), could cause problems for outdoor nursery products, which are vulnerable to waterlogged soils.

Furthermore, weather events that create flooding may intensify erosion along the Connecticut River, where most sod production occurs in Connecticut (Adaptation Subcommittee to the Governor's Steering Committee on climate change, 2010). In New Jersey, salt marsh is encroaching on some sod and nursery farms due to sea level rise (New Jersey Climate Adaptation Alliance, 2014a).

Adaptation strategies that have been identified for the green industry in the Northeast include improving energy efficiency in greenhouses to mitigate the rising energy costs that will likely occur during summer (Coale et al., 2011).

Improving the efficiency of irrigation provides another possible adaptation strategy to contend

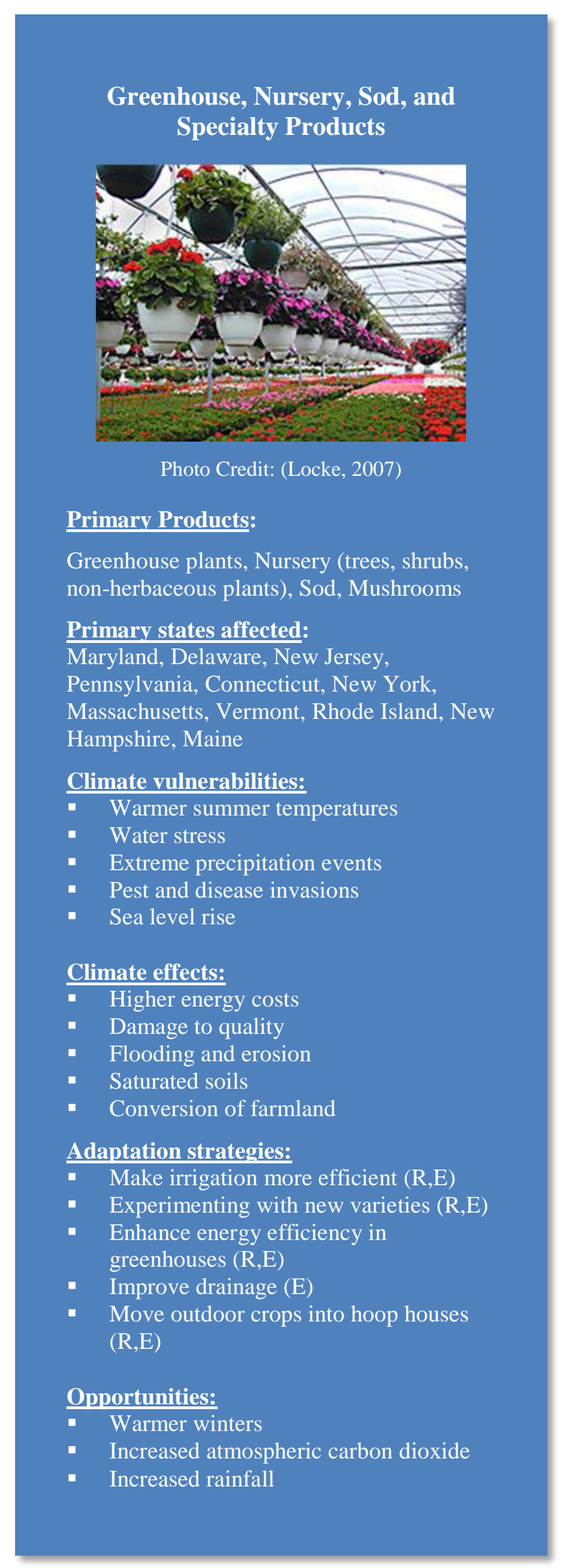




\section{Northeast Region}

with water stress resulting from drought conditions for field grown plants, as does water capture during precipitation events (Adaptation Subcommittee to the Governor's Steering Committee on climate change, 2010). Moving vegetable and other crop production from outdoors into high tunnels to protect against extreme weather events is another strategy that is increasingly being used in the United States and worldwide (Lamont, 2009). Another option to adapt to more frequent drought conditions for nursery owners is to expand production of drought-tolerant plants while reducing production of water-intensive plants (Adaptation Subcommittee to the Governor's Steering Committee on climate change, 2010; New Jersey Climate Adaptation Alliance, 2014b). Additionally, developing and experimenting with new sod varieties with higher resistance to pests and pathogens, and improving drainage for outdoor nursery and sod production inundated by extreme rainfall and flooding may be important adaptation strategies (Adaptation Subcommittee to the Governor's Steering Committee on climate change, 2010).

Although warmer summer temperatures may lead to higher costs for cooling greenhouses, warmer temperatures during winter will likely reduce heating costs (Union of Concerned Scientists, 2008). Furthermore, if higher rainfall amounts occur at opportune times, outdoor nursery production may be enhanced (Adaptation Subcommittee to the Governor's Steering Committee on climate change, 2010). Another opportunity rests in higher levels of atmospheric carbon dioxide, which may benefit plants grown in greenhouses (Adaptation Subcommittee to the Governor's Steering Committee on climate change, 2010).

\section{Ecosystem Services}

Ecosystem services are considered to be those benefits that humans derive from natural functions of healthy, intact ecosystems. Agriculture relies on these services, and contributes to them. Soil and water resources, for example, are critical for agricultural production. At the same time, agriculture has the potential to contribute positively or negatively to soil and water quality, biodiversity conservation, enhanced pollination, and carbon sequestration (Walthall et al., 2012; Wolfe et al., 2011). The ecosystem services provided by soils include providing essential minerals for plant growth, filtering and storing water, cycling nutrients, and sequestering carbon (Walthall et al., 2012). Although ecosystem services provide wide-ranging benefits, they are not always easily quantifiable; and whereas economic values may be calculated for food production, for example, benefits such as climate regulation and aesthetic and cultural values are more difficult to measure (Groffman et al., 2014).

Because agriculture is tightly intertwined with natural resources, production methods implemented by farmers will have implications for ecosystem services. Decisions related to tillage, irrigation, pesticide use, and crop diversification, for example, affect soil health. However, climate change also presents threats to the ecosystem services on which agriculture relies. Higher levels of precipitation and extreme events have the potential to degrade both soil and water resources. As discussed earlier, heavy downpours can cause soil compaction and intensify soil erosion, and also trigger runoff from agricultural fields that can increase contamination of waterways (Adaptation Subcommittee to the Governor's Steering Committee on climate change, 2010; Coale et al., 2011; Nash \& Galford, 2014; Union of Concerned Scientists, 2008; Wolfe et al., 2011).

Warmer summer temperatures and more frequent droughts will likely cause further stress on freshwater resources, particularly if agricultural systems in the region become reliant on irrigation (Adaptation Subcommittee to the Governor's Steering Committee on climate change, 2010; Division of Energy and Climate, 2014; Wolfe et al., 2011). To a lesser yet still concerning degree, sea level rise may also compromise freshwater sources due to salt water intrusions (Adaptation Subcommittee to the Governor's Steering Committee on climate change, 2010; Division of Energy and Climate, 2014). Threats from sea level rise also include the loss of agricultural land in coastal zones, as well as the deterioration of wetlands, marshes, and estuaries, which provide ecosystem services in the form of aquaculture 
production, water filtration, and flood protection (Adaptation Subcommittee to the Governor's Steering Committee on climate change, 2010; Coale et al., 2011; Division of Energy and Climate, 2014).

Other vulnerabilities to ecosystems include a loss of biodiversity (Adaptation Subcommittee to the Governor's Steering Committee on climate change, 2010). Crop pollinators such as bees, for example, perform important roles for maintaining plant biodiversity (Division of Energy and Climate, 2014). Although the links between crop pollinators and climate require further research (Coale et al., 2011), increases in ozone have negative effects on bee populations (Adaptation Subcommittee to the Governor's Steering Committee on climate change, 2010). Furthermore, research has shown that bees are appearing earlier in the spring, causing concern that mismatches in timing may occur between the presence of pollinators and the flowering of plants (Division of Energy and Climate, 2014).

Recognizing the wide-ranging benefits of ecosystems - both economic and noneconomic-is important to facilitate the implementation of adaptation strategies (Walthall et al., 2012). When possible, estimating the costs incurred by farmers and land managers when ecosystem services are lost may be an effective strategy (Division of Energy and Climate, 2014). For example, one study estimated that forests provide $\$ 14,000$ per acre per year in services in the Chesapeake Bay watershed in Delaware (Division of Energy and Climate, 2014). Farmers interested in soil conservation may consider practices such as minimizing tillage and increasing cover crops (Nash \& Galford, 2014; Walthall et al., 2012). Riparian buffers and other buffer strips, as well as better drainage from fields, may contribute to soil stability and minimize detrimental effects of flooding (Division of Energy and Climate, 2014; Nash \& Galford, 2014). Efficient use of nitrogen fertilizer may also help reduce the intensity of chemical runoff (Nash \& Galford, 2014). Stress on water resources might be addressed through efficient systems such as drip irrigation, and through water harvesting and storage (Adaptation Subcommittee to the Governor's Steering Committee on climate change, 2010; Coale et al., 2011; Nash \& Galford, 2014). Maintaining habitats that promote pollinators and managing pests, diseases, weeds, and invasive species are options to help conserve biodiversity

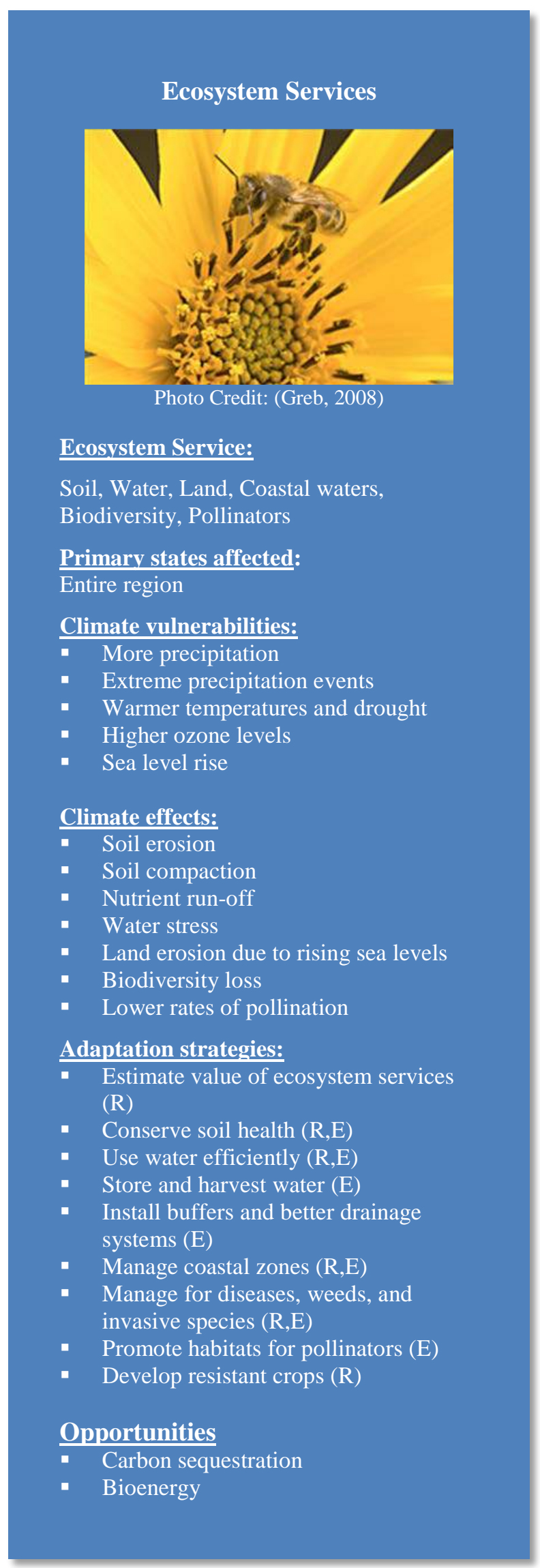




\section{Northeast Region}

(Division of Energy and Climate, 2014; Nash \& Galford, 2014; Walthall et al., 2012). Careful management of coastal ecosystems is worthwhile considering the services they provide to the viability of aquaculture industries (Buonaiuto et al., 2011; Johnson et al., 2011). In Delaware, research is underway to develop salt-tolerant crops that serve as oil and feed crops and are also drought- and flood-tolerant (Division of Energy and Climate, 2014).

Because ecosystems services are both resources and outcomes of agricultural production, the adaption strategies presented may also be considered as opportunities. The enhancement of ecosystem health adds value to farmers to draw upon in the future. In addition to practices that conserve soil and water, other opportunities exist to mitigate climate change, including increasing carbon sequestration and the installation of wind turbines for alternative energy (Nash \& Galford, 2014; Wolfe et al., 2011). Furthermore, opportunities may also exist in reducing energy costs through the use of biomass fuels, especially if their economic efficiency can be enhanced (Helsel \& Specca, 2009; Nash \& Galford, 2014). Possibilities also exist to extend information about ecosystem services into programmatic areas beyond natural resources and agriculture.

\subsection{Livestock Systems Overview of Risks, Vulnerabilities, and General Adaptation Strategies}

Livestock is a key component of agriculture in the Northeast. Dairy, poultry and eggs, other livestock and aquaculture will all be affected by a changing climate. Each has unique vulnerabilities and opportunities for adaptation. The sections below provide an overview of the vulnerabilities in each livestock system and provide general adaptation strategies for each.

\section{Dairy}

Dairy constitutes the most important agricultural activity in the Northeast, especially in New Hampshire, New York, Pennsylvania, and Vermont, where milk is the leading agricultural commodity on the basis of cash receipts (National Agricultural Statistics Service, 2014c). In New York, milk generated about \$2.4 billion in sales in 2012, whereas the dairy industry in Pennsylvania netted nearly $\$ 2$ billion in sales, and comprises 65 percent of the entire agricultural sector in Vermont. In Connecticut, Delaware, Maine, Maryland, Massachusetts, Rhode Island, and West Virginia, milk is a top-five commodity in terms of cash receipts (National Agricultural Statistics Service, 2014c). Given the economic importance of dairy to agriculture in the Northeast, the vulnerability of the industry receives significant attention. Connecticut, for example, has listed dairy among the State's five most vulnerable agricultural sectors (Adaptation Subcommittee to the Governor's Steering Committee on climate change, 2010).

Heat stress presents the most serious threat to the dairy industry in the Northeast. Temperatures ranging from $40^{\circ}$ to $75^{\circ} \mathrm{F}$ offer the ideal conditions for milk production, although high humidity can also cause heat stress for dairy cattle even below $75^{\circ} \mathrm{F}$ (Division of Energy and Climate, 2014; New Jersey Climate Adaptation Alliance, 2014b; Union of Concerned Scientists, 2008; Wolfe et al., 2011). Warming daytime and nighttime temperatures, as are projected to occur during summer, will likely have adverse effects on milk production (Adaptation Subcommittee to the Governor's Steering Committee on climate change, 2010; Griffin, 2009; Nash \& Galford, 2014; Union of Concerned Scientists, 2008; Wolfe et al., 2011). Cows selected for their high production rates are particularly vulnerable to heat stress, and even a few days of high temperatures can have lasting effects on milk production (Wolfe et al., 2011). Heat stress also causes lower birthing rates and feed intake (Adaptation Subcommittee to the Governor's Steering Committee on climate change, 2010; Union of Concerned Scientists, 2008; Wolfe et al., 2011). Declining birthing rates not only reduce herd sizes, but also have implications for milk production, given that dairy cows will not produce milk without a calf (Nash \& Galford, 2014). 
Pennsylvania estimates that heat stress already causes $\$ 50.8$ million in losses per year, and declines in milk production of up to 10 percent by mid-century have been predicted under high greenhouse gas emissions scenarios (Union of Concerned Scientists, 2008). Under these same scenarios, Delaware expects moderate heat stress by mid-century, resulting in production losses ranging from 10 to 25 percent unless cooling measures are employed. In New Jersey, declining milk productivity due to heat stress could cost the State up to $\$ 3.3$ million by late century (New Jersey Climate Adaptation Alliance, 2014b). Warming temperatures and more frequent summer droughts will also likely adversely affect corn grown as feed (Adaptation Subcommittee to the Governor's Steering Committee on climate change, 2010; Coale et al., 2011; Division of Energy and Climate, 2014; Griffin, 2009). Cow susceptibility to illnesses may also increase, especially as pathogens and parasites have more opportunity to multiply with warmer winter conditions (Division of Energy and Climate, 2014; Wolfe et al., 2011). Wetter and muddier conditions may encourage the spread of mastitis and foster respiratory infections (Griffin, 2009).

Because heat stress poses the most serious threat to the dairy industry in the Northeast, many adaptation strategies focus on enhancing cooling systems. For their pastures, dairy farmers may consider increasing shade for herds (Nash \& Galford, 2014). For housing facilities, options focus on increasing air circulation and cooling capacity (Griffin, 2009; Wolfe et al., 2011). Tunnel ventilation that relies on fans and sprinkler and mister systems can help enhance cooling capacity (Adaptation Subcommittee to the Governor's Steering Committee on climate change, 2010; Wolfe et al., 2011). Current facilities could be modified to incorporate these changes (Coale et al., 2011), although older tie-stall barns, which frequently house smaller herds in States such as New York, can be difficult to renovate (Wolfe et al., 2011). When constructing new facilities, dairy farmers are advised to base their plans on climate expectations for the 21st century as opposed to what they have already experienced during their lives (Wolfe et al., 2011). An important consideration is the significant expense of installing ventilation and cooling systems. Wolfe et al. (2011) notes that farmers with larger herds may find their investments more costeffective due to their economies of scale. To assist dairy farmers in New York and elsewhere in making these decisions, Cornell University has created a Website to help dairy farmers perform cost-benefit analyses of tunnel ventilation systems (Wolfe et al., 2011).

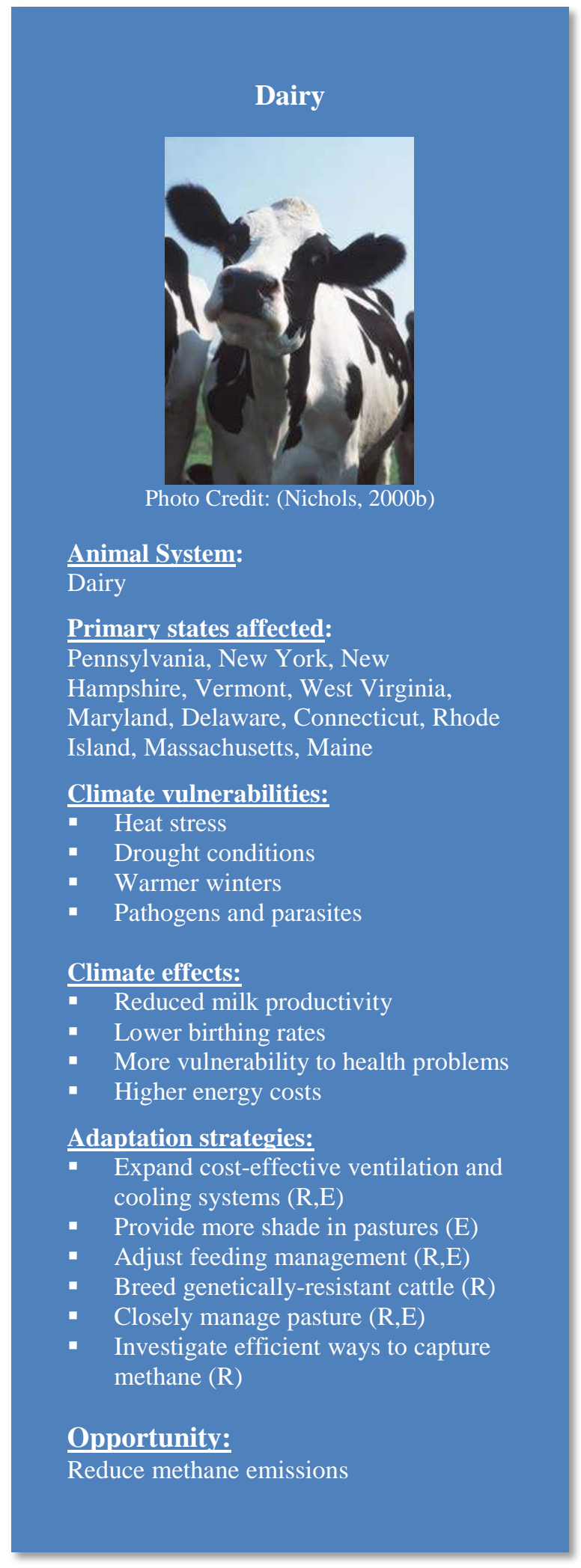

Animal System:

Dairy

Primary states affected:

Pennsylvania, New York, New

Hampshire, Vermont, West Virginia,

Maryland, Delaware, Connecticut, Rhode

Island, Massachusetts, Maine

Climate vulnerabilities:

- Heat stress

Drought conditions

- Warmer winters

- Pathogens and parasites

\section{Climate effects:}

- Reduced milk productivity

- Lower birthing rates

- More vulnerability to health problems

- Higher energy costs

Adaptation strategies:

Expand cost-effective ventilation and cooling systems (R,E)

Provide more shade in pastures $(\mathrm{E})$

- $\quad$ Adjust feeding management (R,E)

- Breed genetically-resistant cattle (R)

- Closely manage pasture $(\mathrm{R}, \mathrm{E})$

Investigate efficient ways to capture methane (R)

Opportunity:

Reduce methane emissions

Regional Agriculture's Sensitivity to Climate Change and Adaptation Strategies

Page | 23 


\section{Northeast Region}

Higher energy costs can be an important consequence of cooling and ventilation system installation (Adaptation Subcommittee to the Governor's Steering Committee on climate change, 2010; Wolfe et al., 2011).

Feeding adjustments can also help dairy cows avoid heat stress. According to Wolfe et al. (2011), these include feeding with easily digestible forages, adding supplements to encourage digestion and replace minerals lost through sweating and panting, ensuring that feeding occurs during cooler parts of the day, and making sure that sufficient water is accessible to cows. Research can also help dairy farmers by breeding animals genetically more tolerant to various climate pressures, including heat stress and pathogen and parasite outbreaks (Division of Energy and Climate, 2014).

The vulnerability of dairy cattle to heat stress implies that there may not be many new opportunities for this industry as a result of climate change. However, heat stress in the Northeast may be less than in other parts of the country.

\section{Poultry and Eggs}

Poultry and eggs are an important aspect of agriculture in the Northeast, particularly in the southern part of the region. In 2012, cash receipts for poultry and eggs provided almost $\$ 923$ million in revenue in Maryland, more than \$811 million in Delaware, and more than \$401 million in West Virginia, ranking this commodity the highest in the agricultural sector in each of these States (National Agricultural Statistics Service, 2014c). As the second most valuable commodity in Pennsylvania, poultry and eggs generated about $\$ 1.3$ billion in sales in 2012. In Connecticut, New Hampshire, New Jersey, and Rhode Island, poultry and eggs ranked among the top five agricultural commodities for each State in 2012 (National Agricultural Statistics Service, 2014c).

Heat stress presents the most problematic climate vulnerability to the poultry industry, although the consequences are mitigated because chickens and turkeys are frequently raised in climate-controlled housing facilities (Division of Energy and Climate, 2014; Wolfe et al., 2011). Maintaining a cool temperature for broiler hens provides the optimal conditions for their health, growth, and disease resistance (Division of Energy and Climate, 2014). Without these controlled conditions, production declines (Coale et al., 2011). Poultry farmers seeking to regulate temperatures within their facilities will likely confront higher cooling costs (Coale et al., 2011; Division of Energy and Climate, 2014; Wolfe et al., 2011).Enhancing ventilation systems may also result in higher maintenance costs (Division of Energy and Climate, 2014). Higher temperatures may also present new disease threats to poultry in the Northeast (Coale et al., 2011).

For poultry houses in low-lying areas, the expectation of increased flooding may also pose a threat to the profitability of the industry (Coale et al., 2011). Extreme precipitation events may affect water quality, which can cause reductions in egg production (Adaptation Subcommittee to the Governor's Steering Committee on climate change, 2010). In States such as Delaware and Maryland, the poultry industry is closely connected with the corn and soybean industries, which provide the basis for feed. Therefore, stresses to field crops may have secondary effects on the poultry industry in the form of higher feed prices and lower feed quality (Adaptation Subcommittee to the Governor's Steering Committee on climate change, 2010; Coale et al., 2011; Division of Energy and Climate, 2014). 
To adapt to rising temperatures, poultry farmers may want to consider upgrading the cooling capacity of their housing facilities through the installation of better ventilation systems and insulation (Division of Energy and Climate, 2014). Improving energy efficiency and increasing reliance on bioenergy may provide other options to mitigate higher energy costs resulting from heat stress (Coale et al., 2011). Farmers who have poultry houses in flood-prone zones may also want to adjust either the design or the location of their facilities (Coale et al., 2011). Disease threats may be mitigated through improved abilities in monitoring and quarantining affected animals (Coale et al., 2011), and research should also investigate chicken breeds with enhanced resistance to heat stress, a research program already underway at the University of Delaware (Division of Energy and Climate, 2014).

Because poultry are generally raised in controlled environments, few new opportunities exist for the industry other than mitigation strategies. However, given the economic benefits that bioenergy may provide to poultry farmers, using this source of energy may play a role in helping to mitigate climate change.

\section{Other Livestock}

Beef cattle, sheep, goats, pigs, and horses are economically important to the Northeast (Adaptation Subcommittee to the Governor's Steering Committee on climate change, 2010). Cattle and calves are the secondmost important agricultural commodity in West Virginia with about $\$ 217$ million in sales in 2012, and they generated almost $\$ 62$ million in sales in Vermont as its third most important agricultural commodity (National Agricultural Statistics Service, 2014c). In Pennsylvania, hogs and pigs were the sixth most important agricultural commodity in 2012, with almost $\$ 458$ million in sales, whereas hogs and pigs are among the top 10 in Delaware, Maryland, New York, and Rhode Island (National Agricultural Statistics Service, 2014c). Collectively, sales of horses, ponies, mules, burros, and donkeys were valued at $\$ 4.7$ million as Delaware's seventh most important agricultural commodity, and rank among the top 10 among the majority of northeastern States. In 2010, Connecticut had one of the highest densities of horses per square mile nationally with a value exceeding $\$ 300$ million (Adaptation Subcommittee to the Governor's Steering Committee on climate change, 2010). Sheep, goats, wool, mohair, and milk constituted the tenth most important agricultural commodity in both Vermont and West Virginia in 2012 (National Agricultural Statistics Service, 2014c).

\section{Poultry and Eggs}

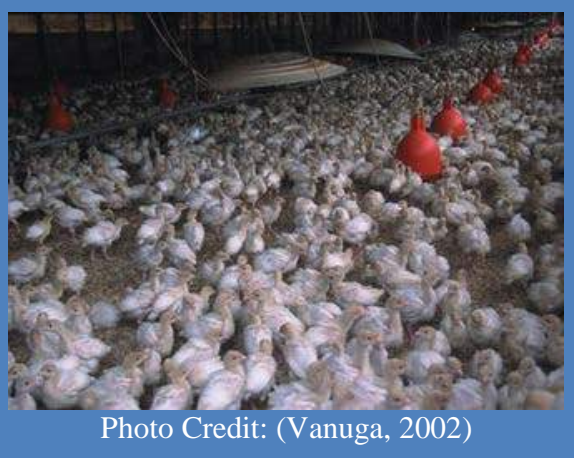

Animal System:

Poultry and Eggs

Primary states affected:

West Virginia, Maryland, Delaware,

Pennsylvania, New Jersey, Connecticut,

New Hampshire, Rhode Island

Climate vulnerabilities:

- Heat stress

- Extreme precipitation

- Flooding

- Pathogens and parasites

Higher energy costs

- Reduced egg production

- Lower meat quality

- Vulnerability to disease

Adaptation strategies:

Expand ventilation and cooling systems (R,E)

- Improve energy efficiency $(\mathrm{R}, \mathrm{E})$

- Alter design and/or location to avoid flood damage $(\mathrm{R}, \mathrm{E})$

- Closely manage field crops (R,E)

- Improve disease monitoring and ability to quarantine $(\mathrm{R}, \mathrm{E})$

- Breed heat-resistant chickens (R)

Improved egg production due to warmer winters

- Mitigate climate change through use of bioenergy

\section{Climate effects:}

\section{Opportunities:}


Rising temperatures are expected to cause heat stress to beef cattle, horses, and sheep that are raised outdoors during summer months (Adaptation Subcommittee to the Governor's Steering Committee on climate change, 2010; Coale et al., 2011; Wolfe et al., 2011). The quality of the pasture on which these animals graze may suffer due to drought (Coale et al., 2011). If farmers have difficulty producing their own feed for livestock animals, they may have to purchase feed, likely at higher prices due to anticipated shortages and diminished quality (Nash \& Galford, 2014). Like poultry, pigs are often raised in indoor facilities and so may not suffer from outdoor temperatures to the same degree as other livestock, but farmers may experience higher energy costs to regulate temperatures (Wolfe et al., 2011). Higher temperatures coupled with higher precipitation may also enhance the presence of mosquitoes or flies, which are often carriers of disease (Adaptation Subcommittee to the Governor's Steering Committee on climate change, 2010). Extreme precipitation may also cause hoof health problems for grazing animals (Adaptation Subcommittee to the Governor's Steering Committee on climate change, 2010).

Adaptation strategies for these other livestock groups in the Northeast are similar to those identified for dairy cattle and poultry. For outdoor animals such as beef cattle, horses, goats, and sheep, providing more shade in pastures will help reduce heat stress, which otherwise can cause animal bunching, less grazing, and diminished weight gain (Wolfe et al., 2011).

Researchers may also identify heat-tolerant breeds to help alleviate detrimental effects of rising temperatures (Coale et al., 2011). To ensure quality pasture, farmers may want to manage these lands for drought through increased irrigation capacity and incorporating drought-resistant varieties (Adaptation Subcommittee to the Governor's Steering Committee on climate change, 2010; Coale et al., 2011).

Educational programs can help educate farmers on drought and the negative effects of heat stress (Coale et al., 2011). Research and extension might help farmers monitor diseases and implement programs to enhance their capacity to quarantine affected animals (Coale et al., 2011). For animals such as pigs raised indoors, farmers may want to adopt enhanced energy efficiency strategies to help address rising energy costs (Coale et al., 2011).

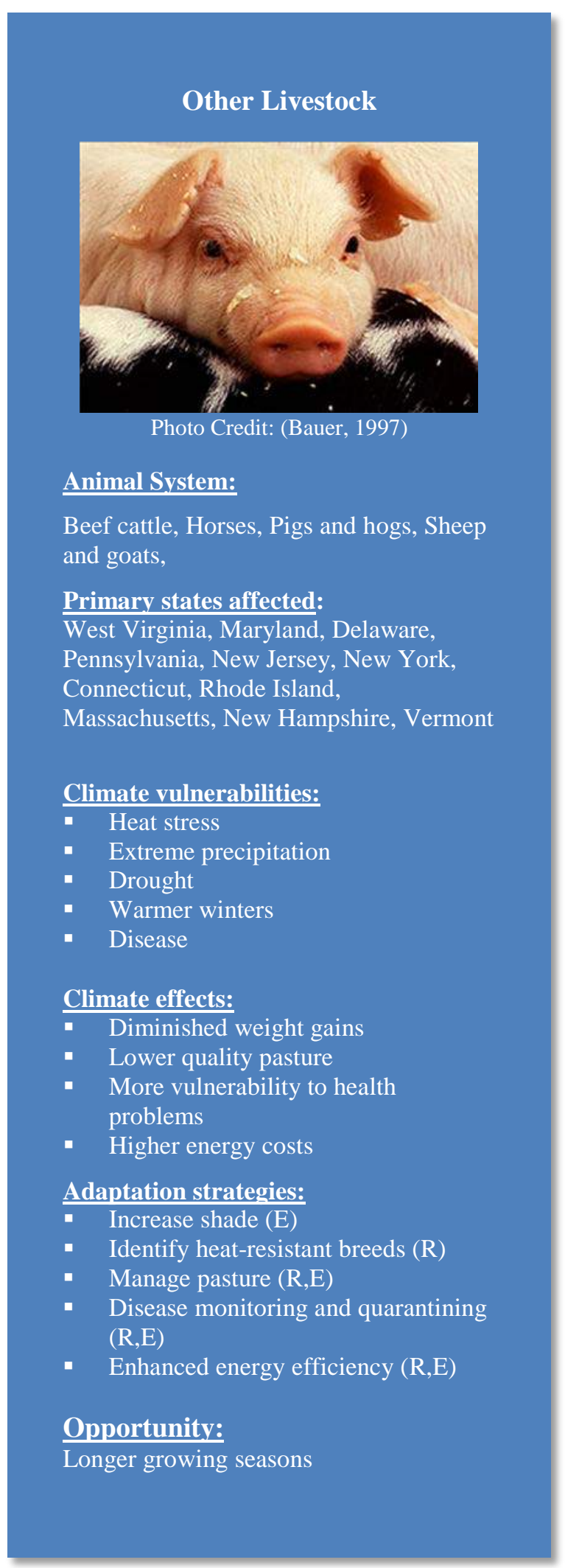




\section{Aquaculture}

With coastline as a prominent feature of many northeastern states, fish and shellfish aquaculture provide an important economic and cultural component of regional market sales. According to the USDA (2014a), "aquaculture is defined as the farming of aquatic organisms including: baitfish, crustaceans, food fish, mollusks, ornamental fish, sport or game fish and other aquaculture products." Given this definition, wild-caught seafood such as Maine lobster are not included in aquaculture considerations (Lapointe, 2013). Aquaculture ranks fifth in terms of market value in Maine and Massachusetts with more than $\$ 75$ million and \$23 million, respectively, in sales in 2012 (National Agricultural Statistics Service, 2014c). In Connecticut, New Jersey, and Rhode Island, aquaculture is among the top 10 most valuable agricultural commodities (National Agricultural Statistics Service, 2014c). These industries are vulnerable to climate change; Connecticut, for example, has identified shellfish as the agricultural commodity that is fourth most vulnerable to climate change (Adaptation Subcommittee to the Governor's Steering Committee on climate change, 2010).

Higher temperatures pose threats to fish and shellfish aquaculture (Adaptation Subcommittee to the Governor's Steering Committee on climate change, 2010). Under even low greenhouse gas emissions scenarios, fish and shellfish in Rhode Island will not likely be able to cope with rising sea temperatures by mid-century (Roberts et al., 2010), thereby damaging existing aquaculture industries (Anderson et al., 2009). Higher sea temperatures may also exacerbate disease risk for animals and present health threats to human consumers (Adaptation Subcommittee to the Governor's Steering Committee on climate change, 2010). Higher atmospheric $\mathrm{CO}_{2}$ concentrations are also causing oceans to become more acidic. This increased acidity poses a threat for shellfish to develop and maintain calcified shells and exoskeletons (Adaptation Subcommittee to the Governor's Steering Committee on climate change, 2010; Buonaiuto et al., 2011; Executive Office of Energy and Environmental Affairs, 2011). Damaged shells and other hard parts of shellfish reduce their

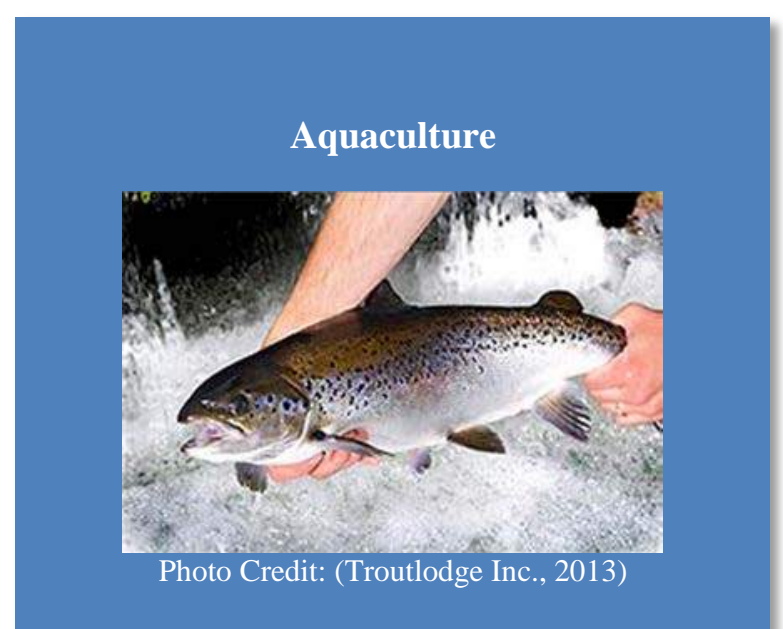

Animal System:

Fish, Shellfish

Primary states affected:

Maine, Massachusetts, Rhode Island,

Connecticut, New York, New Jersey,

Delaware, Maryland

Climate vulnerabilities:

- Warmer sea temperatures

- Increased carbon dioxide in water

- Sea level rise

- Extreme precipitation

Climate effects:

Less than optimal physical functioning and reproduction

- Vulnerability to disease

- Damaged habitats

- Algae blooms/red tide

Adaptation strategies:

Improve monitoring of species populations, disease, and ecosystem health (R)

- Identify disease-resistant shellfish strains (R)

- Relocate infrastructure (R,E)

- Ecosystem management (R,E)

\section{Opportunity:}

Suitable habitat conditions for species in new coastal areas ability to optimally function and reproduce and can make them more vulnerable to disease (Anderson et al., 2009). 


\section{Northeast Region}

Aquaculture is also vulnerable to rising sea levels. Shellfish such as oysters require a proper mix of fresh and salt water, so their habitats in low-lying coastal areas may be threatened as the salinity of water increases due to sea level rise (Executive Office of Energy and Environmental Affairs, 2011; New Jersey Climate Adaptation Alliance, 2014b). Other climate vulnerabilities exist in the form of extreme precipitation (New Jersey Climate Adaptation Alliance, 2014b). Extreme precipitation events threaten coastal habitats and wetlands because run-off can stimulate overgrowth of algae and other microscopic plants that reduce oxygen supplies for fisheries and aquaculture and can produce health concerns for humans such as red tide (Executive Office of Energy and Environmental Affairs, 2011; Johnson et al., 2011; New Jersey Climate Adaptation Alliance, 2014b). In Connecticut, sewage contamination and runoff have already caused the closure of shellfish harvesting areas, an occurrence that may become more frequent with higher precipitation (Adaptation Subcommittee to the Governor's Steering Committee on climate change, 2010).

To help fishing and aquaculture industries adapt to climate change in the Northeast, research will be needed to better understand how the presence of specific species will shift and how harvesting practices can be altered to respond to these changes (Anderson et al., 2009; Executive Office of Energy and Environmental Affairs, 2011). For shellfish that are vulnerable to more acidic ocean conditions, disease monitoring can be implemented to include observations of algae blooms, red tide, and contaminant levels (Anderson et al., 2009). As oceanic conditions change, research might also investigate shellfish strains resistant to disease (Adaptation Subcommittee to the Governor's Steering Committee on climate change, 2010). Although relocating aquaculture infrastructures (i.e., docks and shoreline buildings) is an expensive investment, it presents an option to help the changing habitats of shellfish (Adaptation Subcommittee to the Governor's Steering Committee on climate change, 2010). Careful management of coastal ecosystems such as wetlands, marshes, and estuaries may also help maintain suitable habitats for fish and shellfish populations (Buonaiuto et al., 2011; Johnson et al., 2011).

\section{Forest Systems Overview of Risks, Vulnerabilities, and General Adaptation Strategies}

Forests are a defining landscape feature across the Northeast, covering two-thirds of the region's land area (Shifley et al., 2012). Forests help sustain human communities in the region from ecological, economic, and cultural standpoints. These ecosystems are already responding to changing conditions, and climate change is anticipated to have a pervasive influence on forests in the region over the coming decades.

\subsection{Factors That Increase Risk to Ecosystems}

Adaptive capacity is the ability of a species or ecosystem to accommodate or cope with potential climate change effects with minimal disruption, and is strongly related to the concept of resilience (Glick et al., 2011). A summary of factors that could reduce or increase the adaptive capacity of forest systems within the region is provided below. Greater adaptive capacity tends to reduce climate change vulnerability, and lower adaptive capacity tends to increase vulnerability.

\section{Low-Diversity Systems}

In general, species-rich communities have exhibited greater resilience to extreme environmental conditions and greater potential to recover from disturbance than less diverse ecosystems (Tilman, 1996, 1999). Consequently, less diverse forest types and ecosystems such as aspen, red pine plantations, or black ash swamps may be inherently more susceptible to future changes and stressors (Duveneck et al., 2014; Swanston et al., 2011). Genetic diversity within species is also critical for the ability of populations to adapt to climate change; species with high genetic variation are more apt to have individuals that can withstand extreme events and adapt to changes over time (Reusch et al., 2005).

Forest Systems Overview of Risks, Vulnerabilities, and General Adaptation Strategies

Page $\mid 28$ 


\section{Northeast Region}

\section{Fragmented Landscapes}

Species are generally expected to migrate more slowly than their suitable habitats will shift (Iverson et al., 2004a; Iverson et al., 2004b; McLachlan et al., 2005). Fragmentation makes this disparity even more challenging, particularly in areas with a higher proportion of agricultural land, because the landscape is essentially less permeable to migration (Jump \& Peñuelas, 2005; Scheller \& Mladenoff, 2008). Humans may be able to assist in the migration of species to newly suitable areas to counteract the effects of fragmentation. Assisted migration is a contentious issue for some species (Pedlar et al., 2012; Schwartz et al., 2012).

\section{Systems That Are Limited to Particular Environments}

Several species and forest types in the region are confined to particular habitats on the landscape, whether through particular requirements for hydrologic regimes or soil types, or other reasons. An example is a forest type occurring at higher elevation, such as subalpine spruce-fir. Similar to species in fragmented landscapes, isolated species and systems face additional barriers to migration (Jump \& Peñuelas, 2005) compared with species that have broader ecological tolerances.

\section{Systems That Are Less Tolerant of Disturbance}

Basic ecological theory and other evidence support the idea that systems that have adapted to more frequent disturbances such as drought, flooding, or fire may be better able to withstand climate-driven disturbances. This principle is limited, however, because it is also possible for disturbance-adapted systems to undergo too much disruption.

\subsection{Tree Species and Ecosystem Shifts}

As described previously, changes in climate will have a variety of substantial effects on forest ecosystems. Ecosystems are complex assemblages of species, and so the response of individual species will strongly affect how ecosystems respond as a whole. Additionally, climate change effects will continue within the context of forest management, possibly including active and widespread adaptation efforts. Changes in broad ecosystem types will thus vary from one place to another on the basis of local management decisions and specific influences of site-level environmental factors.

\section{Reduced Habitat for Northern and Boreal Species}

Across northern latitudes, warmer temperatures are expected to be more favorable to individual tree species near the northern extent of their range and less favorable to those near the southern extent (Iverson \& Prasad, 1998). Results from climate impact models project declines in suitable habitat and landscape-level biomass for northern and high-elevation species such as black spruce, red spruce, and paper birch (Butler et al., 2015; Landscape Change Research Group, 2014; Rustad et al., 2012). These northern species may persist in the region throughout the 21 st century, although with declining vigor. Boreal species may remain in areas with favorable soils, management, or landscape features. Additionally, boreal species may be able to persist in the region if competitor species are unable to colonize these areas (Iverson, Prasad, \& Matthews, 2008; Iverson et al., 2011).

\section{Altered Forest Composition}

Species will respond individually to climate change, and this may lead to the dissolution of traditional community relationships (Davis et al., 2005; Root et al., 2003). Past climatic changes resulted in large shifts in species composition (Davis, 1983; Williams et al., 2004). Ecological principles and modeling studies indicate that forest communities may move across the region (Frelich \& Reich, 2010; Iverson, Prasad, Matthews, et al., 2008; Lenihan et al., 2008) and that tree species may also rearrange into novel communities. Changes in forest composition could be accelerated or enhanced by major stand-replacing disturbance events or forest management.

Forest Systems Overview of Risks, Vulnerabilities, and General Adaptation Strategies 


\section{Northeast Region}

Models forecast that species currently near their northern range limits in the region may become more abundant and more widespread under a range of climate futures. These include many oak and hickory species, dogwood, and eastern red cedar. At the same time, observed trends have suggested that other forest species such as balsam fir and red spruce may be more prone to range contraction at southern limits and less able to expand ranges northward (Murphy et al., 2010; Woodall et al., 2013; Zhu et al., 2011). Most species can be expected to migrate more slowly than their suitable habitats will shift (Iverson et al., 2004a; Iverson et al., 2004b; McLachlan et al., 2005). Habitat fragmentation and dispersal limitations could further hinder the northward movement of southerly species despite the increases in available habitat. Pests and diseases such as emerald ash borer, beech bark disease, and Dutch elm disease are also expected to affect some species that are projected to increase. The possibility also exists for nonnative plant species to take advantage of shifting forest communities and unoccupied niches if native forest species are limited (Hellmann et al., 2008). Major shifts in species composition may not be observable until well into the 21 st century because of the long time frames associated with many ecosystem processes and responses to climate change.

\section{Changes in Forest Productivity}

One of the major implications of climate change is the potential for changes in forest productivity, which will be influenced by complex interactions among the degree of warming, ecosystem water balance, and disturbance events (Campbell et al., 2009; Chiang et al., 2008; He et al., 2002; Ollinger et al., 2008). There is evidence both worldwide and regionally that warmer temperatures and longer growing seasons are partially responsible for observed increases in forest growth and carbon sequestration during the past century (McMahon et al., 2010; White et al., 1999). Likewise, there is evidence that carbon dioxide fertilization has contributed to enhanced tree growth over the past two centuries (Cole et al., 2010; Franks et al., 2013; Norby \& Zak, 2011) and may potentially offset some of the effects of drier growing seasons (Franks et al., 2013; Wang et al., 2006).

Although the potential exists for forest productivity to continue increasing under a changing climate, productivity may also be reduced in several ways. In particular, it is uncertain whether the timing and amount of future precipitation will be adequate for overcoming the increased evaporative demand of warmer temperatures. Episodic disturbances such as fires, wind, droughts, and pest outbreaks may also reduce productivity in certain areas over different time scales. Finally, a combined effect of tree species decline and lags in the migration and establishment of more suitable species may result in reduced productivity until a new equilibrium is reached.

\subsection{Considerations by Ecoregion}

Climate change is expected to have wide-ranging effects on forests, which will vary on the basis of geographic location and local site conditions. Within each ecoregion, climate change will have different effects on the drivers, stressors, and dominant tree species that are characteristic of the forest communities within that particular area. This section presents specific considerations of climate change vulnerabilities for the particular ecoregions located in the Northeast.

New England and Northern New York

Forest Systems Overview of Risks, Vulnerabilities, and General Adaptation Strategies

Page 30 


\section{Northeast Region}

The projected changes in climate and the associated effects and vulnerabilities will have important implications for economically valuable timber species, forest-dependent wildlife and plants, recreation, and long-term natural resource planning. Across New England and northern New York, several vulnerability assessments describe potential climate change effects (Manomet Center for Conservation Sciences, 2010, 2012; New Hampshire Fish and Game Department, 2013; Rustad et al., 2012; Tetra Tech Inc., 2013). There are several similar conclusions across these assessments. One of the most consistent findings is the threat of climate change to forest ecosystems dominated by boreal species such as spruce-fir, paper birch, and aspen forests, which are consistently rated as the most vulnerable across numerous vulnerability assessments. Spruce-fir forests are of particular concern under a changing climate because the range of this forest community appears to be largely controlled by the presence of cold temperatures

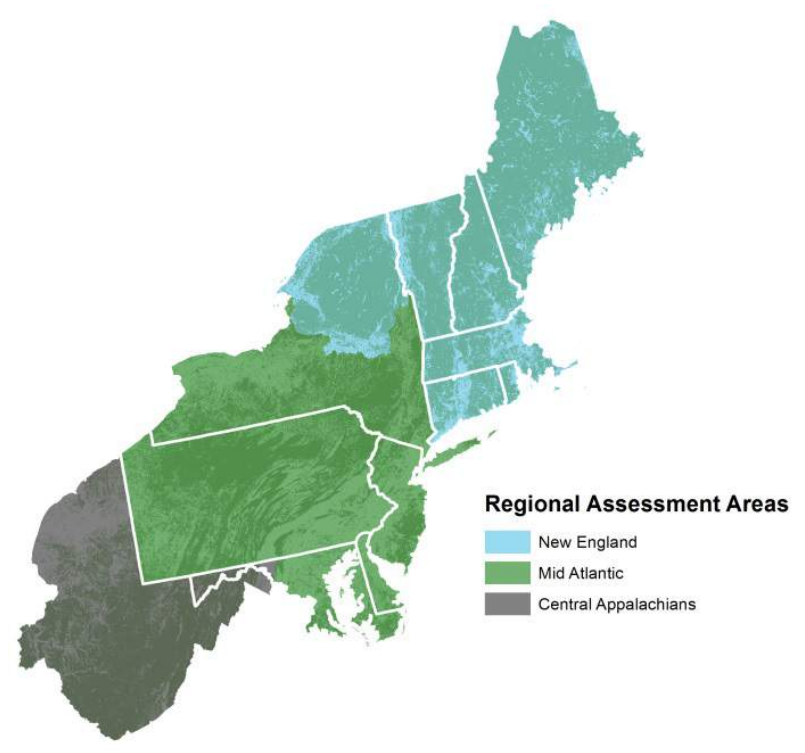
(Manomet Center for Conservation Sciences, 2010, 2012; New Hampshire Fish and Game Department, 2013; Rustad et al., 2012; Tetra Tech Inc., 2013). Likewise, forests that have an abundance of northern species are also rated as more vulnerable. For example, northern hardwood forests dominated by species such as sugar maple, yellow birch, American beech, and eastern hemlock have generally been assessed as being moderately vulnerable to climate change (Manomet Center for Conservation Sciences, 2010, 2012). Declines in the productivity or extent of these forest communities have the potential to dramatically alter other ecosystem components such as dependent wildlife. Wildlife species associated with northern climates and forests, such as the moose, Bicknell's thrush, spruce grouse, fisher, and Canada lynx, may also decrease as boreal conifer species and other key habitat features change (Manomet Center for Conservation Sciences, 2010, 2012; Rodenhouse, 2009).

Climate trends may generally favor hardwood species across the landscape by the end of the century. Forest communities featuring a greater abundance of oak and pine species, such as central hardwoods and pitch pine forest types, have generally been assessed as being less vulnerable to projected changes in climate (Manomet Center for Conservation Sciences, 2010, 2012; Natural Resources Workgroup of the Adaptation Subcommittee to the Governor's Steering Committee on Climate Change, 2010; Tetra Tech Inc., 2013). Results from forest impact models suggest that species such as bitternut hickory, black oak, bur oak, and white oak may have increases in both suitable habitat and biomass, and some deciduous forest types have the potential for productivity increases across the assessment area (Landscape Change Research Group, 2014). Note that forest communities will not be influenced only by shifts in habitat ranges, but also by the ability of species to actually migrate and establish in new areas (Iverson, Prasad, Matthews, et al., 2008; Iverson et al., 2011). Warmer climates are also likely to allow for range expansions of a variety of biological stressors, including insect pests, forest diseases, and invasive plant species (Rustad et al., 2012; Weed et al., 2013).

Changes in forest composition and function resulting from climate change are likely to lead to other changes in the forest sector. Forest industry may face challenges if commercially important tree species decline, particularly if the industry is not prepared for large potential shifts in the availability of commercial species. Shorter winter seasons may also reduce the feasibility of forest harvest operations in 


\section{Northeast Region}

some areas (Rittenhouse \& Rissman, 2015). Maple syrup production, a regionally important forest product, is already being affected by changes in the climate. In central New England, the start of sugaring season has shifted from mid-March to early February, producing a shorter tapping season and lower-grade syrup (Rustad et al., 2012). Additional changes in climate or declines in sugar maple trees could have substantial economic effects due to reduced maple syrup production (Rustad et al., 2012; Skinner et al., 2010). Likewise, changes in seasonality could also affect forest- and nature-based forms of recreation, such as fall foliage tourism, skiing, and snowmobiling (Rustad et al., 2012; Scott et al., 2008).

\section{Mid-Atlantic}

Across the Mid-Atlantic, several modeling efforts and vulnerability assessments describe potential climate change effects on the region (e.g., (Manomet Center for Conservation Sciences, 2012; McKenney-Easterling et al., 2000; Pan et al., 2009)). One of the most consistent findings is the threat of climate change on cool-temperate mixed forests. In general, species and communities adapted to warm, dry conditions are expected to increase, and those adapted to cool, wet conditions are expected to decrease. Forest communities featuring a greater abundance of oak and pine species such as longleafslash pine, loblolly-shortleaf pine, oak-hickory, and oak-pine types, have generally been assessed as being less vulnerable to projected changes in climate (Manomet Center for Conservation Sciences, 2012; McKenney-Easterling et al., 2000). Results from forest impact models suggest that species such as post oak, longleaf pine, loblolly pine, slash pine, shortleaf pine, southern red oak, and white oak may increase in importance (Landscape Change Research Group, 2014; McKenney-Easterling et al., 2000), whereas other species including sugar maple, black cherry, northern red oak, beech, birch, and tulip poplar are expected to decrease (Beecher et al., 2013; Landscape Change Research Group, 2014; McKenneyEasterling et al., 2000). It is important to note that forest communities will not be influenced only by shifts in habitat ranges, but also by the ability of species to actually migrate and establish in new areas (Iverson et al., 2004a).

In addition to direct effects on forests, climate change is also expected to affect a number of forest disturbances and stressors. Existing regeneration problems characteristic of many Mid-Atlantic forests are expected to be exacerbated as trees respond to warmer, drier conditions (Beecher et al., 2013). Deer herbivory is already affecting tree regeneration in the region. These effects are expected to increase with warmer winters and reduced snow cover, which could expose vegetation for winter browsing, reduce winter deer mortality, and allow deer populations to grow (Rosenzweig et al., 2001). Warmer temperatures are also expected to result in range expansions and increased effects from insect pests, forest diseases, and invasive plants (Rustad et al., 2012; Ryan \& Vose, 2012; Weed et al., 2013). Hemlock woolly adelgid and elongate hemlock scale, beech bark disease, emerald ash borer, Asian longhorned beetle, and sudden oak death will increasingly threaten many tree species across the region, especially when combined with drought and other stressors (Beecher et al., 2013).

Other effects from climate change are particularly important in the Mid-Atlantic region because it has a high density of urban infrastructure, substantial greenhouse gas emissions, and significant heat island effects. These combined effects on urban trees and forests may interact with climate change to present unique challenges in forest management. Forest fragmentation is already a forest stressor in the region; expansion of natural gas exploration into northeastern Pennsylvania and southern New York, and the expansion of pipelines and overhead transmission lines are expected to exacerbate forest fragmentation in years to come (Beecher et al., 2013). Fragmentation may slow or prevent species migration, and the reduced genetic diversity within fragments is likely to hinder adaptive evolution (Anderson et al., 2012). In the New Jersey Pine Barrens, effects from southern pine beetle and fire have the potential to affect both forests and human populations near the wildland-urban interface. For example, a 2007 forest fire scorched more than 15,000 acres in the Pine Barrens, and also damaged homes and forced residents to evacuate (Kutner, 2008). 


\section{Northeast Region}

\section{Central Appalachia}

Climate change, including drought, damage from insect pests and diseases, competition with nonnative species, and altered disturbance regimes, is likely to cause similar stress on forests in the central Appalachian Mountains. A forest ecosystem vulnerability assessment completed for the central Appalachians region suggests that some tree species and forest communities may benefit from climate change, whereas others may become more stressed and experience loss of suitable habitat (Butler et al., 2015). Consistent with findings from other regional vulnerability assessments, (Butler et al., 2015) assessed forest ecosystems dominated by boreal species such as red spruce and balsam fir as the most vulnerable to climate change. Spruce-fir forests are of particular concern under a changing climate because the range of this forest community appears to be limited by a cool, moist climate at the highest elevations in the region (Byers et al., 2007; Cogbill \& White, 1991). Forests that have an abundance of northern mesic species such as sugar maple, basswood, yellow birch, American beech, black cherry, and eastern hemlock are also expected to be more vulnerable to climate change (Butler et al., 2015; Manomet Center for Conservation Sciences, 2012). Climate change is also expected to negatively affect riparian systems through amplified effects of altered hydrologic regimes, invasive species, and pollution. Declines in the productivity or extent of these forest communities have the potential to dramatically alter other ecosystem components. For example, wildlife species associated with northern hardwoods and spruce-fir forests, such as the Cheat Mountain salamander, West Virginia northern flying squirrel, and northern sawwhet owl, may also decrease as boreal conifer species and other key habitat features change.

Climate trends may generally favor hardwood species across the landscape by the end of the century. Forest communities featuring a greater abundance of oak, hickory, and pine species have generally been assessed as being less vulnerable to climate change (Butler et al., 2015; Manomet Center for Conservation Sciences, 2012). Habitat for species with ranges that extend largely to the south such as post oak, blackjack oak, southern red oak, and shortleaf pine is expected to increase in the central Appalachians. Loblolly pine, currently only a plantation species, is also expected to fare well under future climates (Landscape Change Research Group, 2014). Many mesic species, including American beech, eastern hemlock, eastern white pine, red spruce, and sugar maple are among those projected to have reductions in suitable habitat, growth potential, and biomass under a high degree of warming over the next century. Note that forest communities will not be influenced only by shifts in habitat ranges, but also by the ability of species to actually migrate and establish in new areas (Iverson et al., 2004a).

Existing forests may also have to compete with undesirable species under warmer future conditions. One example of this is kudzu, an invasive vine that typically transforms invaded forests in the southeastern U.S. by quickly overgrowing and smothering even mature overstory trees. Presently, the northern range of kudzu is limited by winter temperatures but modeling suggests the risk for kudzu invasion could be heightened for many areas under future warming (Bradley et al., 1999; Jarnevich \& Stohlgren, 2009). Warmer climates are also likely to allow for range expansions and increased effects of other biological stressors, including insect pests and forest diseases (Ryan \& Vose, 2012; Weed et al., 2013).

\subsection{Forest Sector Adaptation Strategies}

As an increasing amount of relevant scientific information on forest vulnerability to climate change becomes available, managers are searching for ways to realistically use this information to meet the more specific needs of on-the-ground forest management, including management plans and silvicultural prescriptions (Millar et al., 2012). The amount of information available on the anticipated effects of climate change on ecosystems is growing rapidly, putting high-quality scientific information within reach of most natural resource professionals (Seppälä et al., 2009; Vose et al., 2012). At this point in time, many professionals are shifting their requests for more information to requests for practical and efficient ways to focus and apply existing information. The application of this information can help them adjust

Forest Systems Overview of Risks, Vulnerabilities, and General Adaptation Strategies

Page $\mid 33$ 


\section{Northeast Region}

management, conservation, and restoration priorities and activities to adapt forests to the changes in climate.

\section{Principles of Forest Adaptation}

A great deal of work has occurred to provide conceptual frameworks (e.g., (Millar et al., 2007; Peterson et al., 2011)), compile adaptation strategies (e.g., (Heinz, 2008; Heller \& Zavaleta, 2009; Ogden \& Innes, 2008)), and provide tools to support management decision making (e.g., (Cross et al., 2012; Morelli et al., 2012; Stein et al., 2014; Swanston \& Janowiak, 2012)). The following principles can serve as a starting point for this perspective (Joyce et al., 2008; Millar et al., 2007; Swanston \& Janowiak, 2012; Wisconsin Initiative on Climate Change Impacts, 2011):

- Prioritization and triage: It will be increasingly important to prioritize actions for adaptation on the basis of both the vulnerability of resources and the likelihood that actions to reduce vulnerability will be effective.

- Flexible and adaptive management: Adaptive management provides a decision-making framework that maintains flexibility and incorporates new knowledge and experience over time.

- "No regrets" decisions: Actions that result in a wide variety of benefits under multiple scenarios and have little or no risk may be initial places to consider re-prioritization and seek near-term implementation.

- Precautionary actions: Where vulnerability is high, precautionary actions to reduce risk in the near term, even with existing uncertainty, may be extremely important.

- Variability and uncertainty: Climate change is much more than increasing temperatures; increasing climate variability will lead to equal or greater effects that will need to be addressed.

- Integrating mitigation: Many adaptation actions are complementary with actions to mitigate greenhouse gas emissions, and actions to adapt forests to future conditions can help maintain and increase their ability to sequester carbon.

\section{Strategies, Planning, and Implementation}

In the Midwest and Northeast, the Climate Change Response Framework was launched in 2009 by the USDA Forest Service and is now working in concert with the USDA Regional Climate Hubs to continue providing a set of resources for forest adaptation. These resources are designed to translate largely broadscale and conceptual information into tangible projects that can be put into action and used by forest managers and other natural resource professionals to advance their on-the-ground work (Janowiak et al., 2014; Swanston \& Janowiak, 2012). Among the resources are a "menu" of 50 adaptation strategies and approaches drawn from scientific literature and further vetted by regional forest managers and scientists. Dozens of tactical examples help to further ground these ideas. These adaptation strategies (Table 2) are broadly classified by their desired outcome.

Table 2: Climate Change Adaptation Strategies under Three Broad Adaptation Options

\begin{tabular}{|lcccc|}
\multicolumn{1}{|c}{ Strategy } & Resistance & Resilience & Response \\
\hline 1. Sustain fundamental ecological functions. & X & X & X \\
\hline 2. Reduce the effect of existing biological stressors. & X & X & X \\
\hline 3. Protect forests from severe fire and wind disturbance. & X & X & \\
\hline 4. Maintain or create refugia. & X & & \\
\hline 5. Maintain and enhance species and structural diversity. & X & X & \\
\hline 6. Increase ecosystem redundancy across the landscape. & & X & X \\
\hline
\end{tabular}

Forest Systems Overview of Risks, Vulnerabilities, and General Adaptation Strategies

Page $\mid 34$ 


\begin{tabular}{|c|c|c|c|}
\hline Strategy & Resistance & Resilience & Response \\
\hline 7. Promote landscape connectivity. & & $\mathrm{X}$ & $\mathrm{X}$ \\
\hline 8. Enhance genetic diversity. & & $\mathrm{X}$ & $\mathrm{X}$ \\
\hline 9. Facilitate community adjustments through species transitions. & & & $\mathrm{X}$ \\
\hline 10. Plan for and respond to disturbance. & & & $\mathrm{X}$ \\
\hline
\end{tabular}

Source: (Swanston \& Janowiak, 2012)

The Framework's Adaptation Workbook (www.adaptationworkbook.org) provides a structured process that integrates climate pressures but is fundamentally based on users' original objectives, experience with local forests, and willingness to accept risk. It incorporates vulnerability assessment and adaptation strategies from the menu to ultimately identify adaptation tactics that align with landowner needs and tier to long-term goals. When meeting original objectives appears to be impractical or too high-risk, the user may decide to reconsider original objectives. This approach has been applied in more than 60 real-world forest management projects across numerous ownership types and ranging in size from stand-level silvicultural prescriptions to management plans covering thousands of acres (www.forestadaptation.org). The result across this wide range of users is a diversity of approaches to climate adaptation linked to equally diverse values and objectives.

\section{Summary}

Forests of the Northeast range widely in character and productivity, as do ownership patterns, values, and expectations of the forests. Climate change will exert different pressures for ecosystem change in these forests, and correspondingly present the people who rely on Northeast forests with a variety of challenges. Effective responses to rapid changes in the timing, intensity, and distribution of otherwise familiar stressors and ecosystem drivers can be most efficiently addressed as a community with diverse experience and resources. There is already an active community of forest managers and landowners who are devising practical responses to these challenges, and continued communication and shared learning within this community will best enable heathy and productive forests. 


\section{Greenhouse Gas Emissions Profile from Agriculture and Forests within the Region and Mitigation Opportunities}

Agriculture in the Northeast (including crop, animal, and forestry production) has net greenhouse gas (GHG) emissions of approximately -59 teragrams $^{4}$ of carbon dioxide equivalent ( $\mathrm{Tg} \mathrm{CO}_{2}$ eq.) (i.e., a net uptake and storage of $\mathrm{GHG}$ emissions). In the region, crop-related nitrous oxide $\left(\mathrm{N}_{2} \mathrm{O}\right)$ emissions are the largest contributor to $\mathrm{GHGs}$ at $12 \mathrm{Tg} \mathrm{CO}_{2}$ eq., followed by methane $\left(\mathrm{CH}_{4}\right)$ from enteric fermentation (7 $\mathrm{Tg} \mathrm{CO}_{2}$ eq.) and $\mathrm{CH}_{4}$ and $\mathrm{N}_{2} \mathrm{O}$ from manure management ( $2 \mathrm{Tg} \mathrm{CO}_{2}$ eq.). Forestry ${ }^{5}$ is the largest contributor to net carbon storage at $-80 \mathrm{Tg} \mathrm{CO}_{2}$ eq. followed by soil carbon stock changes ${ }^{6}$ at $-2 \mathrm{Tg} \mathrm{CO}_{2}$ eq. ${ }^{7}$

\subsection{Soill Carbon Stock Changes}

Carbon stock changes of major land use and management type for both mineral and organic soil types resulted in a net sequestration of $-1.76 \mathrm{Tg} \mathrm{CO}_{2}$ eq. in 2008. Specifically, cropland production changes on mineral soils emitted $0.59 \mathrm{Tg} \mathrm{CO}_{2}$ eq., changes in hay production sequestered $-2.82 \mathrm{Tg} \mathrm{CO}_{2}$ eq., and land removed from agriculture and enrolled in the Conservation Reserve Program sequestered $-0.15 \mathrm{Tg}$ $\mathrm{CO}_{2}$ eq. In contrast, agricultural production on organic soils (which have a much higher organic carbon content than mineral soils) resulted in emissions of $0.62 \mathrm{Tg} \mathrm{CO}_{2}$ eq.

Tillage practices contribute to soil carbon stock changes. Table 4 displays the tillage practices by type of crop for the Northeast region. Management practices that utilize reduced till or no-till can contribute to increased carbon storage over time depending on site specific conditions.

Northeast Region Highlights

- Dairy, poultry, beef cattle, corn, soybeans, and hay are the primary agricultural commodities produced in the Northeast.

- The highest source of GHG emissions is $\mathrm{N}_{2} \mathrm{O}$ from croplands.

- Changes in carbon storage in 2008 offset GHG emissions resulting in GHG net storage.

- The greatest mitigation potential is available from changes in land retirement practices.

- Retiring soils from cultivation and establishing conservation cover provides a good opportunity for additional carbon sequestration in the region.

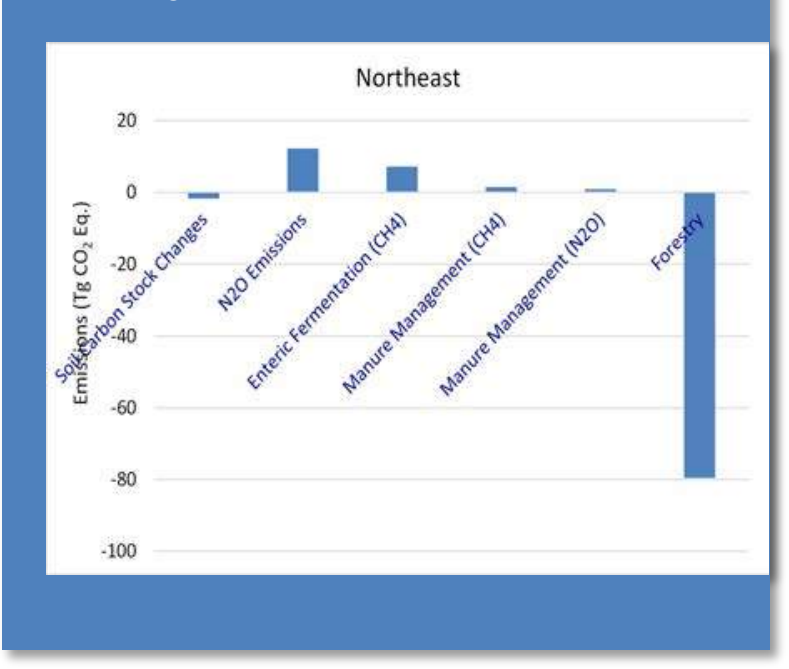

\footnotetext{
${ }^{4}$ A teragram (Tg) is $10^{12}$ grams, which is equivalent to 109 kilograms and 1 million metric tons.

${ }^{5}$ Forestry values encompass non-soil and soil carbon stock changes as well as harvested wood product changes. See Table 8 (U.S. Department of Agriculture, 2011).

${ }^{6}$ Soil carbon includes carbon stock changes on cropland, hay, CRP, and agricultural land on organic soils. See Table 3 (U.S. Department of Agriculture, 2011).

${ }^{7}$ Net carbon storage is the balance between the release and uptake of carbon by an ecosystem. A negative sign indicates that more carbon was sequestered than greenhouse gases emitted.
} 
Table 3:Annual Soil Carbon Stock Changes by Major Land Use and Management Type in the Northeast Region, 2008

\begin{tabular}{|l|c|}
\hline \multicolumn{1}{|c|}{ Land Uses } & $\begin{array}{c}\text { Emissions } \\
\left(\mathrm{Tg} \mathrm{CO} \mathrm{CO}_{2}\right. \\
\text { eq. }\end{array}$ \\
\hline $\begin{array}{l}\text { Net Change, } \\
\text { Cropland }\end{array}$
\end{tabular}

Source: USDA (2011)

${ }^{a}$ Annual cropping systems on mineral soils (e.g., corn, soybean, and wheat).

${ }^{\mathrm{b}}$ Total does not include change in soil organic carbon storage on Federal lands, including those that were previously under private ownership, and does not include carbon storage due to sewage sludge applications.
Table 4: Tillage Practices in the Northeast Region by Crop Type (percent of acres utilizing tillage practice)

\begin{tabular}{|c|c|c|c|c|c|}
\hline $\begin{array}{l}\text { Crop } \\
\text { Type }\end{array}$ & Acres $^{\mathrm{a}}$ & No Till & $\begin{array}{l}\text { Reduced } \\
\text { Till }^{\mathbf{b}}\end{array}$ & $\begin{array}{c}\text { Conventional } \\
\text { Till }^{\mathbf{b}}\end{array}$ & $\begin{array}{c}\text { Other } \\
\text { Conserva } \\
\text { tion } \\
\text { Tillage }^{b}\end{array}$ \\
\hline Hay & $10,421,961$ & N/A & N/A & N/A & N/A \\
\hline Corn & $4,110,287$ & $26 \%$ & $20 \%$ & $42 \%$ & $11 \%$ \\
\hline Soybeans & $1,407,892$ & $68 \%$ & $14 \%$ & $9 \%$ & $9 \%$ \\
\hline Wheat & 308,039 & $28 \%$ & $18 \%$ & $7 \%$ & $48 \%$ \\
\hline Total & $16,248,178$ & & & & \\
\hline
\end{tabular}

\footnotetext{
${ }^{\text {a }}$ Source: USDA (2011)

${ }^{\mathrm{b}}$ Source: USDA ERS (2011). Tillage data not available for most Northeast States; developed tillage practice distributions from data for Michigan, New York, North Carolina, Ohio, and Pennsylvania.
}

\subsection{Nitrous Oxide Emissions}

In 2008, nitrous oxide $\left(\mathrm{N}_{2} \mathrm{O}\right)$ emissions in the Northeast region were approximately $12 \mathrm{Tg} \mathrm{CO}_{2}$ eq. Of these emissions, $9 \mathrm{Tg} \mathrm{CO}$ eq. were emitted from croplands and $3 \mathrm{Tg} \mathrm{CO}_{2}$ eq. were emitted from grasslands. ${ }^{8}$ Because the Northeast region produces hay and corn on the majority of its arable land, the majority of crop-related $\mathrm{N}_{2} \mathrm{O}$ emissions in the region (more than 70 percent) are from the production of these two crops (National Agricultural Statistics Service, 2014b).

As indicated in Table 4, the majority of $\mathrm{N}_{2} \mathrm{O}$ direct emissions are from hay crops. Emissions from hay cropping are substantial, despite minimal fertilizer nitrogen additions, because a large portion of hay includes nitrogen-fixing plants (e.g., alfalfa) (U.S. Department of Agriculture, 2011). The quantity and timing of nitrogen-based fertilizer affects the rate of both direct and indirect $\mathrm{N}_{2} \mathrm{O}$ emissions. ${ }^{9}$ Table 5 indicates the percentage of national acres that did not meet the rate or timing criteria as defined by Ribaudo et al. (2011). Timing criteria is defined in terms of best practices for quantity and timing of fertilizer application. Meeting the best-practice rate criterion is defined as applying no more nitrogen (commercial and manure) than 40 percent more than that removed with the crop at harvest on the basis of the stated yield goal, including any carryover from the previous crop. Meeting the best-practice-timing criterion is defined as not applying nitrogen in the fall for a crop planted in the spring (Ribaudo et al., 2011). Acreages not meeting the criteria represent opportunities for GHG mitigation.

\footnotetext{
${ }^{8}$ Including both direct and indirect emissions; Table 4 includes only direct emissions from crops.

${ }^{9}$ Direct $\mathrm{N}_{2} \mathrm{O}$ emissions are emitted directly from agricultural fields and indirect $\mathrm{N}_{2} \mathrm{O}$ emissions are emissions associated with nitrogen losses from volatilization of nitrogen as ammonia $\left(\mathrm{NH}_{3}\right)$, nitrogen oxides $(\mathrm{NOx})$, and leaching and runoff.
}

\section{Greenhouse Gas Emissions Profile from Agriculture and Forests within the Region and Mitigation Opportunities}


Northeast Region

\begin{tabular}{|c|c|c|}
\hline Crop Type & $\begin{array}{c}\text { Direct } \mathrm{N}_{2} \mathrm{O} \\
\text { Emissions } \\
\left(\mathrm{Tg} \mathrm{CO}_{2} \text { eq.) }\right.\end{array}$ & $\begin{array}{c}\% \text { of Region's } \\
\text { Cropland } \mathrm{N}_{2} \mathrm{O} \\
\text { Emissions }\end{array}$ \\
\hline Hay & 3.19 & 47.6 \\
\hline Corn & 1.78 & 26.6 \\
\hline Soybean & 0.32 & 4.8 \\
\hline Wheat & 0.05 & 0.8 \\
\hline $\begin{array}{l}\text { Non-major } \\
\text { Crops }\end{array}$ & 1.35 & 20.2 \\
\hline Total & 6.70 & 100.0 \\
\hline
\end{tabular}

Table 5: National Percentage of Acres Not Meeting Rate and Timing Criteria (Percent of Acres)

\begin{tabular}{|c|c|c|} 
Crop & $\begin{array}{c}\text { Not Meeting } \\
\text { Rate }\end{array}$ & $\begin{array}{c}\text { Not Meeting } \\
\text { Timing }\end{array}$ \\
\hline Corn & $35 \%$ & $34 \%$ \\
\hline Sorghum & $24 \%$ & $16 \%$ \\
\hline Soybeans & $3 \%$ & $28 \%$ \\
\hline Wheat & $34 \%$ & $11 \%$ \\
\hline
\end{tabular}

Source: Ribaudo et al., (2011).

Source: USDA (2011).

\subsection{Livestock GHG Profile}

Livestock systems in the Northeast focus primarily on the production of swine, beef and dairy cattle, sheep, poultry, goats, and horses. There were more than 230 million head of poultry in the region in 2008 . Beef and dairy cattle are the next-largest livestock population, with more than 2 million animals in each category, followed by swine with more than 1 million head (U.S. Department of Agriculture, 2011). Nearly 51 percent of the cattle in the region are dairy cattle. As with patterns in livestock production across the country, the primary source of GHGs from livestock is from enteric fermentation, digestive processes that result in the production of methane $\left(\mathrm{CH}_{4}\right)$ (referred to as enteric $\left.\mathrm{CH}_{4}\right)$. In 2008, Northeast livestock produced 7.31 $\mathrm{Tg} \mathrm{CO}$ eq. of enteric $\mathrm{CH}_{4} \cdot{ }^{10}$ Most of the remaining livestock-related GHG emissions are from manure management practices, which produce both $\mathrm{CH}_{4}$ and $\mathrm{N}_{2} \mathrm{O} .{ }^{11}$ In 2008, manure management in the Northeast region resulted in $2.3 \mathrm{Tg} \mathrm{CO}_{2}$ eq., considering both $\mathrm{CH}_{4}$ and $\mathrm{N}_{2} \mathrm{O}$, with the majority attributed to $\mathrm{CH}_{4}$ (U.S. Department of Agriculture, 2011).

Table 6: Emissions from Enteric Fermentation in the Northeast, in $\mathrm{Tg}$ of $\mathrm{CO}_{2}$ eq. and as a Percent of Regional Emissions

\begin{tabular}{|c|c|c|}
\hline Animal Category & $\mathrm{Tg} \mathrm{CO}$ & $\begin{array}{l}\% \text { of Region's } \mathrm{CH}_{4} \\
\text { Enteric Emissions }\end{array}$ \\
\hline Beef Cattle $^{\mathrm{a}}$ & 1.69 & 23.1 \\
\hline Dairy Cattle $^{\mathrm{a}}$ & 5.54 & 75.8 \\
\hline Goats $^{\mathrm{b}}$ & 0.00 & 0.1 \\
\hline Horses $^{b}$ & 0.03 & 0.4 \\
\hline Sheep $^{b}$ & 0.01 & 0.1 \\
\hline Swine $^{b}$ & 0.04 & 0.6 \\
\hline Total & 7.31 & 100.0 \\
\hline
\end{tabular}

${ }^{\text {a }}$ Source: USDA (2011)

${ }^{\mathrm{b}}$ Source: Based on animal population from USDA (2011) and emission factors as provided in IPCC (2006)

\subsection{Enteric Fermentation}

The primary emitters of enteric $\mathrm{CH}_{4}$ are ruminants (e.g., cattle and sheep). Emissions are produced in smaller quantities by other livestock such as swine, horses, and goats. The per-head emissions of enteric $\mathrm{CH}_{4}$ for dairy cattle are 40 to 50 percent greater than for beef cattle (e.g., 2.2 metric tons $\mathrm{CO}_{2}$ eq. per head per year for dairy vs. 1.6 metric tons for beef in 2008 due primarily to their greater body weight and greater energy requirements for extended periods of lactation (U.S. Environmental Protection Agency,

\footnotetext{
${ }^{10}$ The enteric $\mathrm{CH}_{4}$ emissions total for the region includes cattle and non-cattle.

${ }^{11}$ Livestock respiration also produces carbon dioxide $\left(\mathrm{CO}_{2}\right)$, but the effects of ingesting carbon-based plants and expelling $\mathrm{CO}_{2}$ result in zero-net emissions.
}

Greenhouse Gas Emissions Profile from Agriculture and Forests within the Region and Mitigation Opportunities 


\section{Northeast Region}

2014). In the Northeast region, because 51 percent of all cattle are dairy cattle and they individually generate more $\mathrm{CH}_{4}$ than beef cattle, the overall contribution to enteric $\mathrm{CH}_{4}$ emissions from dairy cattle of enteric fermentation is more than three times greater than for beef cattle (U.S. Department of Agriculture, 2011). Table 6 provides $\mathrm{CH}_{4}$ emissions by animal types for 2008 .

\subsection{Emissions from Manure Management Systems}

Manure management in the Northeast resulted in $1.5 \mathrm{Tg} \mathrm{CO}_{2}$ eq. of $\mathrm{CH}_{4}$ and $0.8 \mathrm{Tg} \mathrm{CO}_{2}$ eq. of $\mathrm{N}_{2} \mathrm{O}$ in 2008. Table 7 provides a summary of $\mathrm{CH}_{4}$ and $\mathrm{N}_{2} \mathrm{O}$ emissions by animal category. Dairy cattle, swine, and poultry waste account for the majority of manure emissions, with dairy waste accounting for 64 percent of $\mathrm{CH}_{4}$ and 67 percent of $\mathrm{N}_{2} \mathrm{O}$, swine waste accounting for 19 percent and 4 percent, and poultry waste accounting for 9 percent and 22 percent, respectively.

The distribution of animal population among different farm sizes varies across animal categories. For example, in the Northeast, 89 percent of dairy cattle are on farms with fewer than 1,000 head, whereas animals are more evenly distributed across farm sizes for swine. Mitigation technologies such as anaerobic digesters ${ }^{12}$ are more economically feasible on large farm operations due to economies of scale; potential for anaerobic digesters is more limited in the Northeast relative to other regions due to the prevalence of smaller farms. Figure 4 provides a summary of $\mathrm{CH}_{4}$ and $\mathrm{N}_{2} \mathrm{O}$ emissions by animal category and baseline manure management practices. ${ }^{13}$ The largest sources of $\mathrm{CH}_{4}$ are anaerobic lagoons, deep pits, and liquid/slurry systems, primarily with dairy and swine waste. The largest sources of $\mathrm{N}_{2} \mathrm{O}$ are dairy dry lots, dairy solid storage, and poultry operations with bedding. Figure 5 describes the proportion of beef cattle, dairy cattle, and swine that are managed using various manure management systems. The majority of beef waste is deposited on pasture, whereas dairy and swine waste is managed using a variety of systems, including anaerobic lagoons, deep pits, dry lots, and liquid/slurry systems.
Table 7: 2008 Emissions from Manure Management in the Northeast, in $\mathrm{Tg}$ of $\mathrm{CO}_{2} \mathrm{eq}$. and as a Percent of Regional Emissions

\begin{tabular}{|c|c|c|c|c|c|}
\hline \multicolumn{2}{|l|}{ Animal } & \multicolumn{2}{|l|}{ Methane } & \multicolumn{2}{|c|}{ Nitrous Oxide } \\
\hline Category & Population & $\begin{array}{c}\mathrm{Tg} \\
\mathrm{CO}_{2} \mathrm{eq}\end{array}$ & Percent & $\begin{array}{c}\mathrm{Tg} \\
\mathrm{CO}_{2} \mathrm{eq}\end{array}$ & Percent \\
\hline Swine & $1,314,700$ & 0.29 & 19 & 0.03 & 4 \\
\hline $\begin{array}{l}\text { Dairy } \\
\text { Cattle }\end{array}$ & $2,241,507$ & 0.96 & 64 & 0.57 & 67 \\
\hline Beef Cattle & $2,155,663$ & 0.04 & 3 & 0.06 & 7 \\
\hline Poultry & $230,898,486$ & 0.13 & 9 & 0.18 & 22 \\
\hline Horses $^{a}$ & 875,062 & 0.07 & 4 & & \\
\hline Sheep $^{a}$ & 294,180 & 0.00 & 0 & & \\
\hline Goats $^{\mathrm{a}}$ & 130,125 & 0.00 & 0 & & \\
\hline & $237,909,723$ & 1.49 & 100 & 0.84 & 100 \\
\hline
\end{tabular}

Source: USDA (2011)

${ }^{a} \mathrm{~N}_{2} \mathrm{O}$ emissions are minimal and not included in this total. 
Figure 4: $2008 \mathrm{CH}_{4}$ and $\mathrm{N}_{2} \mathrm{O}$ Emissions from the Northeast by Animal Category and Management System (Tg of $\mathrm{CO}_{2}$ eq.)

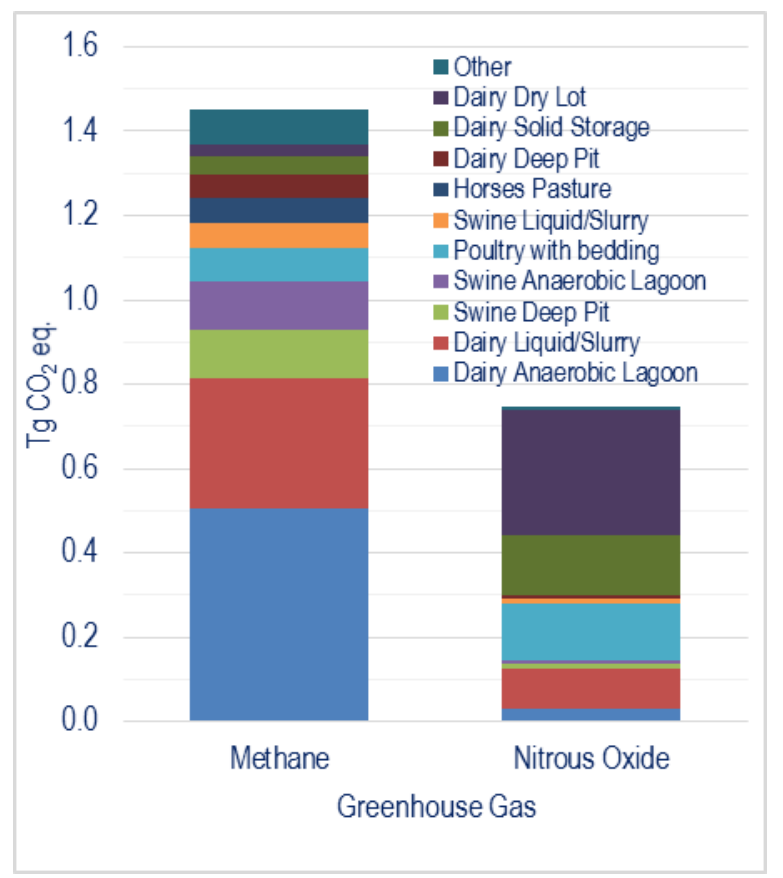

Source: EPA (2010)
Figure 5: Proportion of Beef Cattle, Dairy Cattle, and Swine Managed with Each Manure Management System in the Northeast

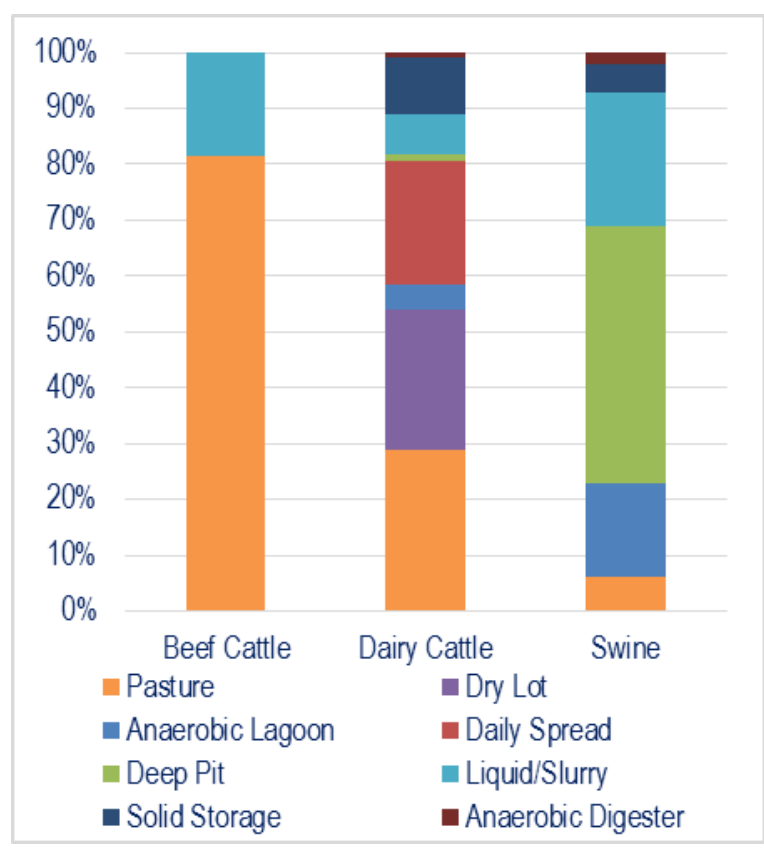

Source: EPA (2010)

\subsection{Forest Carbon Stocks and Stock Changes}

In the annual GHG inventory reported by the USDA, forests and harvested wood products from forests sequester $80 \mathrm{Tg} \mathrm{CO}$ eq. per year in the Northeast; in addition, the 84.6 million acres of forest land in the Northeast maintain $23,570 \mathrm{Tg} \mathrm{CO}_{2}$ eq. in forest carbon stocks. ${ }^{14}$

Managed forest systems in the Northeast focus primarily on the production of hardwood and softwood timber, in addition to serving as riparian buffers and wind breaks. Forestry activities represent significant opportunities for managing GHGs. Forest managers in the Northeast use a wide variety of silvicultural techniques to achieve management objectives, most of which will have effects on the carbon dynamics. The primary effects of silvicultural practices on forest carbon include enhancement of forest growth (which increases the rate of carbon sequestration) and forest harvesting practices (which transfers carbon from standing trees into harvested wood products and residues, which eventually decay or are burned as firewood or pellets). Other forest management activities will result in accelerated loss of forest carbon, such as when soil disturbance increases the oxidation of soil organic matter, or when prescribed burning releases $\mathrm{CO}_{2}$ (as well as $\mathrm{N}_{2} \mathrm{O}$ and $\mathrm{CH}_{4}$ ).

\footnotetext{
${ }^{14}$ Other GHGs, such as $\mathrm{N}_{2} \mathrm{O}$ and $\mathrm{CH}_{4}$, are also exchanged by forest ecosystems. $\mathrm{N}_{2} \mathrm{O}$ may be emitted from soils under wet conditions or after nitrogen fertilization; it is also released when forest biomass is burned. $\mathrm{CH}_{4}$ is often absorbed by the microbial community in forest soils but may also be emitted by wetland forest soils. When biomass is burned in either a prescribed fire/control burn or in a wildfire, precursor pollutants that can contribute to ozone and other short-lived climate forcers as well as $\mathrm{CH}_{4}$ are emitted (U.S. Department of Agriculture, 2014b).
} 


\section{Northeast Region}

Forest management activities and their effects on carbon storage vary widely across the Northeast with different forest types, ownership objectives, and forest stand conditions. However, there are commonly used silvicultural prescriptions for common forest types in the Northeast. For example, the USDA's Quantifying Greenhouse Gas Fluxes in Agriculture and Forestry: Methods for Entity-Scale Inventory Technical Bulletin (2014b) provides this information for the same Northeast region (see Table 6-6 on page 6-59 of that document).

The USDA's Forest Service 2010 Resources Planning Act Assessment General Technical Report (2012) describes future projections of forest carbon stocks in the United States resulting from various vulnerabilities (e.g., less-than-normal precipitation, above-normal temperature) and other stressors (e.g., urbanization, other land development, demand for forest fuel and fiber). The Resources Planning Act (RPA) Assessment projects that "declining forest area, coupled with climate change and harvesting, will alter forest-type composition in all regions." For example, the report notes that for a larger region (i.e., the North) that includes the Northeast, the rate of gain in urban area is second in the country, and the projected reduction in forest inventory is the largest. Oak-hickory, the largest forest type in region, elm-ash-cottonwood, and aspen-birch areas are projected to decline, whereas maple-beech-birch area is projected to increase.

\begin{tabular}{|c|c|c|}
\hline Source & Units & Northeast \\
\hline Net Area Change & $1,000{\text { ha } \mathrm{yr}^{-1}}^{-1}$ & $-23^{\mathrm{a}}$ \\
\hline Non-Soil Stocks & $\mathrm{Tg} \mathrm{CO}{ }_{2}$ eq. & 14,839 \\
\hline Soil Organic Carbon & $\mathrm{Tg} \mathrm{CO}_{2}$ eq. & 8,731 \\
\hline Non-Soil Change & $\underset{\mathrm{yr}^{-1}}{\mathrm{Tg} \mathrm{CO}_{2} \text { eq. }}$ & -71 \\
\hline $\begin{array}{l}\text { Harvested Wood Products } \\
\text { Change }\end{array}$ & $\underset{\mathrm{yr}^{-1}}{\mathrm{Tg} \mathrm{CO}}$ & -9 \\
\hline \multicolumn{3}{|c|}{ Forest Carbon Stock Summary ( $\left.\mathrm{Tg} \mathrm{CO}{ }_{2} \underline{\text { eq. }}\right)$} \\
\hline Non-Soil Stocks + SOC & & 23,570 \\
\hline \multicolumn{3}{|c|}{ 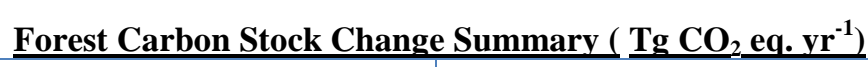 } \\
\hline Forest Carbon Stock Change & & -80 \\
\hline
\end{tabular}

Source: USDA (2011)

${ }^{a}$ Negative values indicate a net removal of carbon from the atmosphere.

\subsection{Mitigation Opportunities}

Figure 6 presents the mitigation potential by sector for the Northeast region. Each bar represents the GHG potential below a break-even price of $\$ 100 /$ metric ton $\mathrm{CO}_{2}$ eq. ${ }^{15} \mathrm{~A}$ break-even price is the payment level (or carbon price) at which a farm will view the economic benefits and the economic costs associated with adoption as exactly equal. Conceptually, a positive break-even price represents the minimum incentive level needed to make adoption economically rational. A negative break-even price suggests the following: 1) no additional incentive should be required to make adoption cost-effective; or 2) there are nonpecuniary factors (such as risk or required learning curve) that discourage adoption. The break-even price is determined through a discounted cash-flow analysis such that the revenues or cost savings are equal to the costs. ${ }^{16}$ The left two bars in Figure 6 represent reductions from changes in management practices that mitigate GHGs. The right three bars represent increased carbon storage from changes in management practices. A total of $0.34 \mathrm{Tg} \mathrm{CO}_{2}$ eq. can be mitigated at a break-even price below $\$ 100 /$ metric tons $\mathrm{CO}_{2}$ eq. Changes in land management practices can increase carbon storage by $2.3 \mathrm{Tg}$ $\mathrm{CO}_{2}$ eq. at a break-even price below $\$ 100 /$ metric tons $\mathrm{CO}_{2}$ eq. The color shading within a bar represents the mitigation potential or the potential increased carbon storage below different break-even prices

\footnotetext{
${ }^{15}$ Break-even prices are typically expressed in dollars per metric ton of $\mathrm{CO}_{2}$ eq. This value is equivalent to $\$ 100,000,000$ per Tg of $\mathrm{CO}_{2}$ eq. or $\$ 100,000,000$ per million metric tons of $\mathrm{CO}_{2}$ eq.

${ }^{16}$ See ICF International (2013) for additional details.
}

Greenhouse Gas Emissions Profile from Agriculture and Forests within the Region and Mitigation Opportunities 


\section{Northeast Region}

indicated in the legend. For example, changes in land retirement practices have the potential to contribute to $0.7 \mathrm{Tg} \mathrm{CO} 2$ eq. of increased carbon storage for less than $\$ 20 /$ metric ton $\mathrm{CO}_{2}$ eq. (i.e., light blue and light green bar).

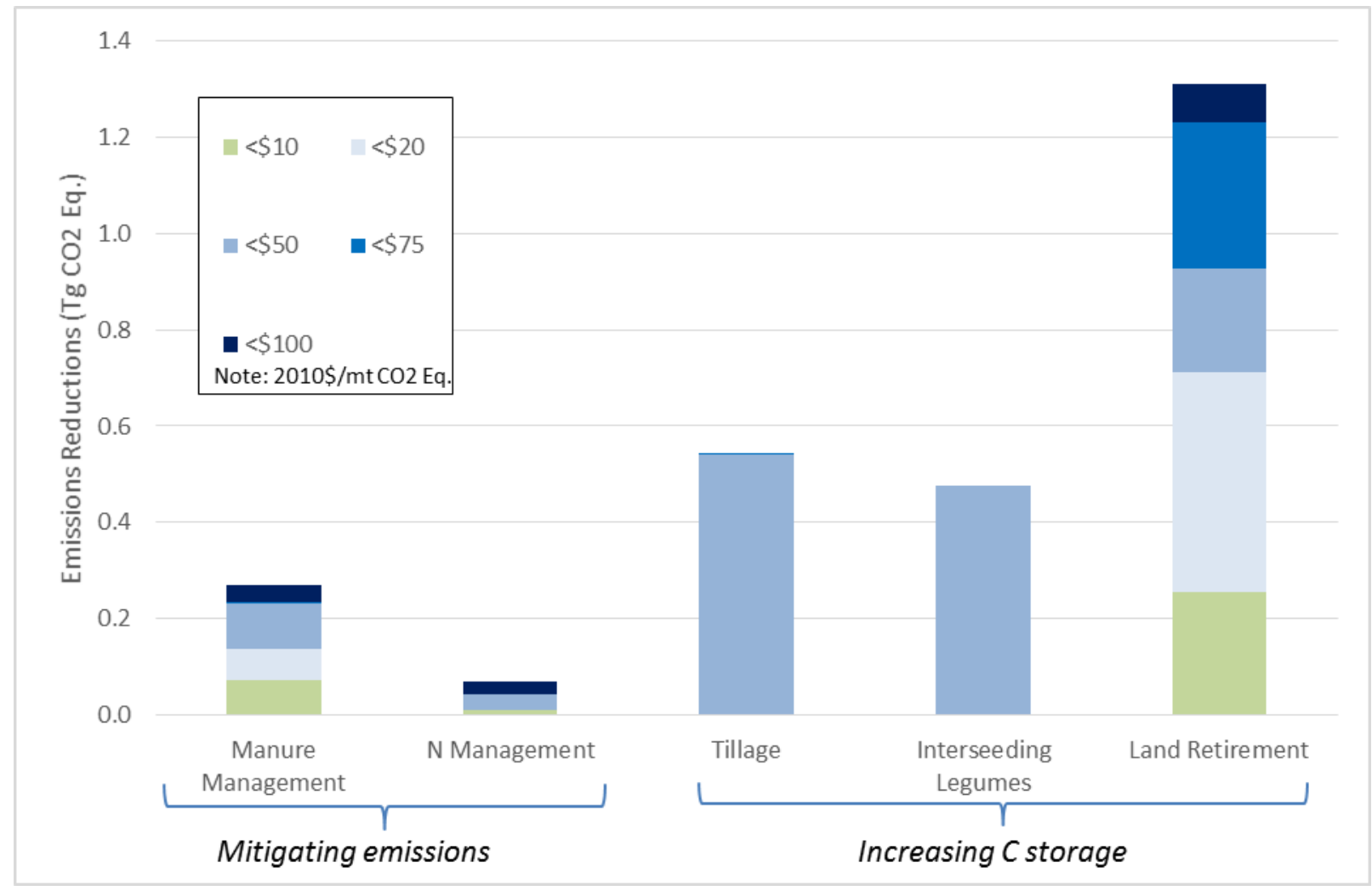

Figure 6: Mitigation Potential in the Northeast, by Sector

A summary of the high-level findings for Northeast mitigation opportunities is provided below:

- Most of the opportunity for reducing net GHG emissions is by increasing carbon stock in land retirement practices, such as retiring organic and marginal soils.

- The next-largest opportunities are by increasing net carbon storage from tillage practices.

- The highest reductions in emissions from manure management are installing improved separators at dairy farms and complete mix digesters with electricity generation at swine and dairy farms with anaerobic lagoons. ${ }^{17}$

\section{Agricultural Soils}

For farms larger than 250 acres, variable rate technology is a relatively low-cost option for reducing $\mathrm{N}_{2} \mathrm{O}$ emissions from fertilizer application. ${ }^{18}$ Reducing nitrogen application can be a relatively low-cost option for all farm sizes. Transitioning from conventional tillage to continuous no-tillage or reduced tillage to

\footnotetext{
${ }^{17}$ The emission reduction excludes indirect emission reductions from the reduced use of fossil fuels to supply the electricity for on farm use (i.e., the emission reductions only account for emissions within the farm boundaries).

${ }^{18}$ Variable rate technology (VRT), a subset of precision agriculture, allows farmers to more precisely control the rate of crop inputs to account for differing conditions within a given field. VRT uses adjustable rate controls on application equipment to apply different amounts of inputs on specific sites at specific times (Alabama Precision Ag Extension, 2011).
}

Greenhouse Gas Emissions Profile from Agriculture and Forests within the Region and Mitigation Opportunities 


\section{Northeast Region}

continuous no-tillage field management practices results in relatively large potential for carbon storage at low cost (i.e., the magnitude of the carbon storage potential is orders of magnitude higher than the potential to reduce $\mathrm{N}_{2} \mathrm{O}$ emissions). Carbon gains can only be realized if no-till is adopted permanently, otherwise gains will be reversed.

\section{Land Retirement}

This category includes retiring marginal and organic soils from cultivation and establishing conservation cover, restoring wetlands, establishing windbreaks, and restoring riparian forest buffers. Retiring organic soils from cultivation and restoring forested wetlands provide the most opportunities for increasing carbon storage in the Northeast region.

\section{Manure Management}

The total $\mathrm{CH}_{4}$ mitigation potential for livestock waste in the Northeast is $0.3 \mathrm{Tg} \mathrm{CO}_{2}$ eq. Lower-cost GHG mitigation opportunities for manure management are primarily for large swine and dairy operations. The greatest $\mathrm{CH}_{4}$ reductions can be achieved on dairy operations by transitioning from anaerobic lagoons to better solids separators or a complete mix digester. For large swine operations, the greatest and most costeffective mitigation measures are to transition from anaerobic lagoons, deep pits, or liquid/slurry systems to complete mix digesters.

\section{Enteric Fermentation}

Emissions from enteric fermentation are highly variable and are dependent on livestock type, life stage, activity, and feeding situation (e.g., grazing, feedlot). Several practices have demonstrated the potential for efficacy in reducing emissions from enteric fermentation. Although diet modification (e.g., increasing fat content, providing higher-quality forage, increasing the protein content) and providing supplements (e.g., monensin, bovine somatotropin [bST]) have been evaluated for mitigation potential, the effectiveness of each option is not conclusive.

\section{USDA Programs}

The recently published USDA Climate Change Adaptation Plan ${ }^{19}$ presents strategies and actions to address the effects of climate change on key mission areas including agricultural production, food security, rural development, forestry, and natural resources conservation. USDA programs administered through the Agriculture Research Service (ARS), Natural Resources Conservation Service (NRCS), U.S. Forest Service (USFS), Farm Service Agency (FSA), Rural Development (RD), Risk Management Agency (RMA), and Animal and Plant Health Inspection Service (APHIS) have been and will continue to play a vital role in sustaining working lands in a variable climate and are key partner agencies with the USDA Climate Hubs. In the Northeast, Hub partner agencies are also vulnerable to climate variability and have programs and activities in place to help stakeholders respond to climate-induced stresses.

\subsection{Natural Resource Conservation Service}

The Natural Resource Conservation Service (NRCS) has many conservation practices and programs that can provide technical and financial assistance to help producers adapt to climate change effects. Conservation practices include cover crops, conservation tillage, and conservation crop rotation to increase soil resilience on cropland; prescribed grazing to improve pastures; reducing greenhouse gases

\footnotetext{
${ }^{19}$ The 2014 USDA Climate Change Adaptation Plan includes input from eleven USDA agencies and offices. It provides a detailed vulnerability assessment, reviews the elements of USDA's mission that are at risk from climate change, and provides specific actions and steps being taken to build resilience to climate change. Find more here: http://www.usda.gov/oce/climate_change/adaptation/adaptation_plan.htm
} 


\section{Northeast Region}

from confined livestock operations by manure management; sequestering carbon through tree planting; developing habitat that supports wildlife; and controlling excessive runoff through water management. All NRCS conservation practices are updated on a regular cycle to stay current with changing climate. NRCS programs that are particularly important in the Northeast relate to preventing soil erosion through cover crops and other soil health practices.

Programs that support and promote the adoption of these practices through financial assistance include the Environmental Quality Incentives Program (EQIP), Conservation Stewardship Program (CSP), Agricultural Conservation Easement Program (ACEP), and the Regional Conservation Partnership Program (RCPP).

NRCS can further assist in helping farmers and other technical service providers with products that help assess and measure effects associated with climate change and the ability to adapt to these changes. NRCS maintains many databases, tools and assessments that could be utilized directly or in conjunction with other climate-related tools.

\subsection{U.S. Forest Service}

The Forest Service approach for adapting to climate change encompasses 1) climate-specific strategies across the agency and 2) direct program-by-program efforts to integrate climate-related policies and guidance where climate change is one of many drivers of change to be considered in sustaining forest and grassland ecosystems. The Eastern Region's forest management plan points to vulnerabilities in the following areas:

- Managing for northern and boreal tree species at the southern edge of their current range will become more challenging as their current habitat becomes less suitable (and moves northward) and re-establishment in a warmer climate becomes more difficult. In the Northeast, balsam fir, spruce, and paper birch are particularly vulnerable tree species.

- Fish and wildlife species that rely on cold-water streams and boreal forest habitats may be particularly vulnerable to climate change.

- Warmer temperatures and increases in tree mortality could increase the efforts required to prevent or contain wildfires.

- Many invasive species, insect pests, and pathogens could benefit from a longer growing season and milder winters, increasing the amount of effort to control them or remove dead and dying trees.

- Increases in heavy precipitation events could place additional stressors on infrastructure such as roads and culverts, and require greater effort to prevent erosional losses during harvest.

- The large amount of private land and fine-scale fragmentation of forest landscapes will make it challenging to implement climate change adaptation.

The Eastern Region measures its climate change response through the Climate Change Performance Scorecard. ${ }^{20}$ Since 2011, each National Forest and Grassland has used a 10-point scorecard to report accomplishments and plans for improvement on 10 questions in four dimensions - organizational capacity, engagement, adaptation, and mitigation. By 2015, each is expected to answer yes to at least seven of the scorecard questions, with at least one yes in each dimension. The goal is to create a balanced approach to climate change that includes managing forests and grasslands to adapt to changing conditions, mitigating climate change, building partnerships across boundaries, and preparing our employees to understand and apply emerging science.

${ }^{20}$ http://www.forestadaptation.org/node/157 


\section{Northeast Region}

The Northern Institute of Applied Climate Science (NIACS) is a collaborative effort among the Forest Service, universities, and forest industry to provide information on managing forests for climate change adaptation, enhanced carbon sequestration, and sustainable production of bioenergy and materials. As a regional, multi-institutional entity, NIACS builds partnerships, facilitates research, and synthesizes information to bridge the gap between carbon and climate science research and the information and management needs of land owners and managers, policymakers, and members of the public. A major effort coordinated by NIACS is the Climate Change Response Framework discussed earlier in this document. The framework is an integrated set of tools, partnerships, and actions to support climate-smart conservation, and it provides a collaborative approach to incorporate climate change into forest management. The framework covers six regional projects in the Midwest and Northeast: Central Appalachians, Central Hardwoods, Mid-Atlantic, New England, Northwoods, and Urban. Each regional project interweaves four components-science and management partnerships, vulnerability assessments, adaptation resources, and demonstration projects. More information is available at www.forestadaptation.org.

Forest Service Northern Research Station scientists are deeply involved in research to understand the processes and extent of global climate change and their probable/possible effects on forest ecosystems. What processes in forest ecosystems are sensitive to physical and chemical changes in the atmosphere? How will future physical and chemical climate changes influence the structure, function, and productivity of forest and related ecosystems; and to what extent will forest ecosystems change in response to atmospheric changes? What are the implications for forest management and how must forest management activities be altered to sustain forest productivity, health, and diversity? More information is available at www.nrs.fs.fed.us/disturbance/climate_change/.

The Forest Service Northeastern Area, State and Private Forestry division serves private landowners through a number of programs. The Forest Stewardship Program (FSP) helps private forest landowners develop plans for the sustainable management of their forests. In addition, the Forest Legacy Program (FLP) and the Community Forest and Open Space Conservation Program (CFP) support the retention of private forests. The mission of the division's Forest Health Protection program is to protect and improve the health of America's rural, wildland, and urban forests. More than 250 specialists in forest entomology, forest pathology, invasive plants, pesticide use, survey and monitoring, fire suppression and control, technology development, and other forest health-related services provide expertise to forest land managers throughout the Nation. Cooperative forestry programs assist forest landowners with programs that encourage conservation practices.

\subsection{Farm Service Agency}

Farm Service Agency (FSA) farm program work is, for the most part, in direct response to what is affecting producers. There are 170 service centers and 13 FSA State offices in the Northeast. FSA dollars out and program activity spike when natural disasters occur. Climate variability arguably means more frequent disasters and thus, for FSA, more producer requests and needs to which staff must respond. Ultimately, with greater demand, FSA may not be able to provide timely customer service to producers when multiple disasters must be managed at once.

As FSA implements the 2014 Farm Bill, the focus is on educating growers and building producer participation in FSA's new and improved disaster assistance and risk management programs: ARC/PLC, MPP-Dairy, and NAP.

The Margin Protection Program for Dairy (MPP-Dairy) is a voluntary risk management program that offers protection to dairy producers when the difference between the all-milk price and the average feed cost (the margin) falls below a certain dollar amount selected by the producer. 


\section{Northeast Region}

The Agriculture Risk Coverage (ARC) Program and Price Loss Coverage (PLC) Program provide a choice of either revenue or price loss protection to eligible producers for the 2014 through 2018 crop years.

The Noninsured Crop Disaster Assistance Program (NAP) provides financial assistance to producers of noninsurable crops to protect against natural disasters that result in lower yields or crop losses, or prevents crop planting. It also offers new buy-up and eligibility for organic and direct-marketed crop provisions that are critical to Northeast farmers. The region has a great diversity of crops, many of which are not eligible for conventional insurance. Northeast producers depend on NAP policies to help protect them when low yields, loss of inventory, or prevented planting occur due to natural disasters.

In the Northeast, fruits, vegetables, mollusks, and working forests have been particularly vulnerable to more frequent and extreme weather events. Producers contend with extreme temperature fluctuations bringing damaging hail; late frosts and freezes affecting fruit trees and vine crops; tropical storms and hurricanes causing both flooding and erosion inland and damage to mollusk operations along the coasts; and tornadoes, microbursts, and ice storms that damage public and private forestlands. In addition to extreme events, periods of excessive moisture during the growing season have challenged vegetable growers as well as dairy producers growing hay for livestock.

FSA's Emergency Conservation Program (ECP) and Emergency Forest Restoration Program (EFRP) have been a great help to producers in New England and throughout the Northeast. For instance, ECP assisted farmers to rehabilitate farmland damaged by heavy flooding caused by Tropical Storm Irene in 2011, whereas over the last decade, EFRP has helped private forest landowners restore forests ravaged by ice storms, tornadoes, and microburst events.

The Northeast is receiving increasing numbers of Presidential and Secretarial Disaster Declarations. The latter are specific to natural disasters affecting agriculture, and determinations are recommended to the Secretary of Agriculture by State Emergency Boards chaired by FSA State Executive Directors. Secretarial declarations make FSA emergency loans available to producers to help them recover from disasters when other credit may not be readily available.

\subsection{Rural Development}

Rural Development (RD) supports rural communities through loans, loan guarantees, and grants. For some RD programs, the agency holds liens or other security interests in facilities and related infrastructure in areas that could be affected by hydrological changes and sea level rises resulting from effects such as inundation and erosion. Additionally, many climate change models predict greater frequency and severity of weather events such as tornados and hurricanes, which can damage utility facilities and infrastructure. Climate change therefore represents a risk to these agency assets and the communities they serve. RD administers services through the Rural Housing Service, Rural Business-Cooperative Service, and Rural Utilities Service.

Within the Northeast region the occurrence of more intense precipitation/floods, warmer temperatures, and intensifying weed, pest, and disease outbreaks are anticipated to cause disruption in electric and other energy supplies, and increased damage to structures/infrastructure from flooding,

\section{Rural Housing Service}

The Rural Housing Service (RHS) administers programs that provide loans and grants for quality housing and community facilities for rural residents within the Northeast region. RHS will implement the prevention measures listed below in an effort to reduce the effects of climate change and help people become more resilient to adverse effects predicted to be incurred by flooding, storm surges, hurricanes, 
tropical storms and other severe weather patterns that could adversely affect structures funded through RHS programs.

1. RHS will continue to provide training to staff on proper siting of facilities/infrastructure for the life-of-structure (30 to 50 years in some cases) in locations where the effects from climate change will not adversely affect the facility or the surrounding environment.

2. RHS will also continue to consider the effects of sea level rise, other potential flooding, and severe weather effects into long term planning.

3. RHS will continue to provide funding for the following programs that have been designed to lessen the need for fossil fuels, promote renewable energy, and increase energy efficiency in an effort to reduce the effects of climate change:

- Multi-family Housing Energy Efficiency Initiative

- Multi-family Housing Portfolio Manager, Capital Needs Assessment/Utility Usage

- Energy Independence and Security Act compliance (which affects new construction of single family housing)

- Climate Action Plan installation of 100 megawatt capacity onsite renewable energy multifamily housing by 2020

\section{Rural Business-Cooperative Service}

The Rural Business-Cooperative Service (RBS) administers programs that lessen the need for fossil fuels, promote biomass utilization and renewable energy, and increase energy efficiency within all of the Climate Hub regions. The Rural Energy for America Program lowers the demand on base energy plants by investing in energy efficiency and renewable energy. Lower base load demand conserves water and helps to reduce greenhouse gases that contribute to climate change. Renewable energy investments can provide extra resiliency by distributing energy resources. RBS is investing in alternative fuels, renewable chemicals, biogas, wastewater conservation, and harvesting the combustible thinnings from forests for use in advanced biofuels.

\section{Rural Utilities Service}

The Rural Utilities Service (RUS) administers programs that provide clean and safe drinking water and sanitary water facilities, broadband, telecommunications, and electric power generation and transmission/distribution within all of the Climate Hub regions. The following programs or measures will help address resiliency and lessen the effect of droughts, floods, and other natural disasters and increase energy efficiency:

- National Rural Water Association (NRWA) Grant-RUS administers this grant to NRWA, which designed to promote energy-efficient practices in small-water and wastewater systems. Through the grant, RUS performs energy assessments, recommends energy-efficient practices and technologies, and provides support to achieve those recommendations.

- Memorandum of Agreement (MoA) between the Unites States Environmental Protection Agency and the United States Department of Agriculture - Rural Development Rural Utilities Service - Promoting Sustainable Rural Water and Wastewater Systems. The goals of this MoA are to increase the sustainability of drinking water and wastewater systems nationwide to ensure the protection of public health, water quality, and sustainable communities; ensure that rural systems have a strong foundation to address 21 st century challenges; and assist rural systems in implementing innovative strategies and tools to allow them to achieve short- and long-term sustainability in management and operations.

- Emergency Community Water Assistance Grants (ECWAG)—This grant program assists rural communities that have experienced a significant decline in quantity or quality of drinking 


\section{Northeast Region}

water due to an emergency, or in which such decline is considered imminent, to obtain or maintain adequate quantities of water that meet the standards set by the Safe Drinking Water Act. Emergencies are considered to include incidents such as drought, earthquake, flood, tornado, hurricane, disease outbreak, or chemical spill, leakage, or seepage.

- Electric Program - Energy Efficiency and Conservation Loan Program (EECLP)—This program is "for the purpose of assisting electric borrowers to implement demand side management, energy efficiency and conservation programs, and on-grid and off-grid renewable energy systems." Goals of the program include: 1) increasing energy efficiency at the end user level; 2) modifying electric load such that there is a reduction in overall system demand; 3 ) effecting a more efficient use of existing electric distribution, transmission, and generation facilities; 4) attracting new businesses and creating jobs in rural communities by investing in energy efficiency; and 5) encouraging the use of renewable energy fuels for either demand side management or the reduction of conventional fossil fuel use within the service territory.

- Principles, Requirements and Guidelines (PR\&G) - Application of the revised PR\&G in the near future to RUS water and wastewater program planning will include consideration of effects of climate change among other factors.

- Rural Development Climate Change Adaptation Planning Document-This document, from June 2012, applies to all three RD agencies. The plan was prepared to in support of Departmental efforts to respond to EO 13514 (Federal Leadership in Environmental, Energy, and Economic Performance) and DR 1070-001. The Planning Document discusses increased efforts at risk assessment and identifies five specific actions related to climate change planning and adaptation.

- Engineering Design Standards and Approved Materials-The RUS electric program envisions expanded incorporation of climate change-related effects as it revised its standards and materials for RUS-financed infrastructure. Already, some borrowers, for example in coastal areas and the Great Plains, have received agency approval for so-called hardened electric poles and lines.

\subsection{Risk Management Agency}

The Risk Management Agency (RMA) provides a variety of actuarially sound crop- and livestock-related insurance products to help farmers and ranchers manage the risks associated with agricultural production. Coverage is provided against agricultural production losses due to unavoidable natural perils such as drought, excessive moisture, hail, wind, hurricane, tornado, lightning, insects, and so on. In 2014, the Federal crop insurance program provided U.S. agricultural producers with more than $\$ 109.8$ billion in protection for agricultural commodities. These policies provide financial stability for agricultural producers and rural communities, and are frequently required by lenders.

Because climate change is an ongoing process, the risk environment for agricultural production will also be undergoing constant change (e.g., some perils may occur with greater or lesser frequency and severity). Climate change will also promote adaptive responses by producers, such as adopting new production practices, planting new varieties, or shifting the locations of farming operations.

RMA continually strives to improve the effectiveness of programs by refining insurance offers to recognize changes in production practices, and where appropriate, adjusting program parameters (e.g., premium rates, planting dates, etc.) within each county to recognize structural changes to the risks of growing the crop in those areas. In that regard, RMA monitors climate change research and, to the extent that climate changes emerge over time, update these program parameters to reflect such adaptation or 


\section{Northeast Region}

other changes. RMA also updates loss adjustment standards, underwriting standards, and other insurance program materials to ensure that they are appropriate for prevailing production technologies.

RMA's Raleigh Regional Office manages insurance programs in the Northeast Hub region: Connecticut, Delaware, Maine, Maryland, Massachusetts, New Hampshire, New Jersey, New York, Pennsylvania, Rhode Island, Vermont, and West Virginia (and North Carolina and Virginia).

In 2010, the national crop insurance liability (crop value insured) was $\$ 78$ billion and in 2014 the national crop insurance liability was $\$ 109.8$ billion. The 12 States located in the Northeast Hub region accounted for more than $\$ 1.4$ billion in liability in 2010 , and this increased to more than $\$ 1.8$ billion in liability in 2014. Although the Northeast makes up a small book of business for the crop insurance program, it is an important risk management tool for grain and specialty crop growers.

Over the last 5 years (2010-2014) participation has grown and crop insurance liabilities was highest in three states (Maryland, New York, and Pennsylvania):

- Maryland total liability grew from \$270 million in 2010 to more than \$364 million in 2014; New York's total liability went from $\$ 369$ million in 2010 to more than $\$ 554$ million in 2014; and Pennsylvania total liability went from \$389 million in 2010 to more than \$514 million in 2014 .

- Over the last 5 years the top six crops with the highest losses reported in these three States were apples, corn, grapes, onions, soybeans, and wheat.

- In 2014, the crop with the most liability exposure for the top three states was corn. Corn had the highest liability of $\$ 651$ million; soybeans had a liability of $\$ 355$ million followed by apples, with a liability of $\$ 121$ million. These three crops have the highest liability exposure for the Federal crop insurance program in the Northeast Hub region.

RMA in the Northeast will continue to monitor crop disasters such as hurricane, freeze, excess precipitation, and drought and respond to approved insurance providers and producer inquiries during these events. In addition, RMA's Raleigh Regional Office will continue to provide estimates of liabilities, losses, and potential effect natural disasters may have to the crop insurance program, as needed.

\subsection{Animal and Plant Health Inspection Service}

The Animal and Plant Health Inspection Service (APHIS) is responsible for protecting and promoting U.S. agricultural and forest health, regulating certain genetically engineered organisms, enforcing the Animal Welfare Act, and carrying out wildlife damage management activities. APHIS is constantly working to defend U.S. plant and animal resources from agricultural and forest pests and diseases. Once a pest or disease is detected, APHIS works in partnership with affected regions to manage and eradicate the outbreak. In its new Strategic Plan for 2015, APHIS lists seven goals:

1. Prevent the entry and spread of agricultural pests and diseases.

2. Ensure the humane treatment and care of vulnerable animals.

3. Protect forests, urban landscapes, rangelands and other natural resources, as well as private working lands from harmful pests and diseases.

4. Ensure the safety, purity, and effectiveness of veterinary biologics and protect plant health by optimizing our oversight of genetically engineered (GE) organisms.

5. Ensure the safe trade of agricultural products, creating export opportunities for U.S. producers.

6. Protect the health of U.S. agricultural resources, including addressing zoonotic disease issues and incidences, by implementing surveillance, preparedness and response, and control programs.

7. Create an APHIS for the 21st century that is high-performing, efficient, adaptable, and embraces civil rights. 


\section{Northeast Region}

APHIS works to achieve these goals through the actions of several mission area program staffs and support units. The text below discusses the APHIS programs and their respective responsibilities, as well as their expected vulnerabilities related to a changing climate and the measures in place to minimize risks from these vulnerabilities. As an agency with nationwide regulatory concerns, APHIS programs are typically national in scope and application.

\section{Animal Care}

Animal Care's mission is to protect animal welfare by enforcing the Animal Welfare Act and the Horse Protection Act. AC protects animals and their owners by supporting FEMA-led emergency pet evacuations necessitated by disasters such as hurricanes.

APHIS Animal Care's non-statutory mission to support FEMA for the well-being of household pets during disasters is vulnerable to climate change. More storms and more severe storms are predicted as the climate warms and consequently activities in this mission area may increase. Animal Care's statutory mission to ensure the welfare of animals used in commerce, exhibition, and research may change as well. For example, the availability of water may change the economics of these industries resulting in a decrease in activities in certain parts of the country.

Animal Care sponsors and participates in planning and exercise activities together with FEMA, Emergency Support Function (ESF) \#11, ${ }^{21}$ States, nongovernmental organizations, and other response partners to strengthen the Nation's capacity to respond to natural disasters. These efforts should help reduce the effect of disaster and help people recover more quickly.

\section{Biotechnology Regulatory Services}

To protect plant health, Biotechnology Regulatory Services (BRS) implements the APHIS regulations for GE organisms that may pose a risk to plant health. APHIS coordinates these responsibilities along with the other designated Federal agencies as part of the Federal Coordinated Framework for the Regulation of Biotechnology.

None of BRS' actions are directly "vulnerable" to climate change. However, because climate change would likely affect the distribution of some agricultural crops and other plants, BRS actions related to conducting inspections of field trials for GE plants could be affected. Therefore, if growing areas for regulated GE plants shift, BRS would need to conduct inspections in those new locations.

BRS has in place a flexible staffing plan and practice. Not all of their staff are centrally located; they are set up to provide mobile inspection service to wherever GE crops are growing in field trials. Additionally, BRS receives reports each year from those holding permits for conducting field trials. BRS uses this information to plan inspections throughout the life cycle of the field trials. The flexibility and regular use of new information inherent in BRS planning and practice will help minimize risks from climate change.

\section{Plant Protection and Quarantine}

APHIS Plant Protection and Quarantine (PPQ) is responsible for safeguarding and promoting U.S. agricultural health. PPQ is constantly working to defend U.S. plant and forest resources from agricultural pests and diseases. Once a quarantine plant pest or disease (one not previously found in the U.S. or if found, is under official control) is detected, PPQ works in partnership with affected regions to manage and eradicate the outbreak. PPQ has three strategic goals:

1. Strengthen PPQ's pest exclusion system,

2. Optimize PPQ's domestic pest management and eradication programs, and

\footnotetext{
${ }^{21}$ http://www.fema.gov/pdf/emergency/nrf/nrf-esf-11.pdf
} 


\section{Northeast Region}

3. Increase the safety of agricultural trade to expand economic opportunities in the global marketplace.

In the face of an increasingly variable climate and more erratic weather conditions, PPQ will continue to play a central role in responding to risk and managing vulnerabilities. In this capacity, PPQ operates primarily on a national level with regional emphasis as needed to address and divert pest incursions.

PPQ is tasked with assessing pest risk by predicting where an invasive plant pest may be introduced and establish, and by modeling its subsequent spread. These assessments are often based on climatic conditions and host availability from a national perspective. As climate changes, host distribution and landscape conditions deviate from what is considered normal. PPQ assessments are based on available data that often reflect past conditions. As climate changes, the actual relevance of these data may lessen our ability to accurately predict and understand risk.

Some of the challenges in predicting future risk under climate change require a shift from analyzing mean responses (e.g., a temperature increase of 2 to $3^{\circ} \mathrm{F}$ on average), and instead focus on trying to understand how pest invasiveness and establishment potential change with increased weather variability and increased extreme events. For example, several years of warmer than normal weather can allow the development of invading pest populations and their spread to new areas. Once arriving in new areas, if such pest populations can secure warmer microclimates to survive the winter, they can become more prevalent earlier the following season. Anticipating global trade shifts in response to climate change is another challenge, as is the subsequent risk of new crop pests and diseases associated with them.

PPQ Science and Technology is partnering with other agencies, universities, and the climate hubs to increase our capacity to obtain and analyze data, and implement models that inform climate changespecific policies and pest programs. We have increased our capacity to perform pest risk modeling at regional, national, and global levels with new platforms. These platforms are designed to project climate change scenarios onto the landscape to model geographic shifts in climatic suitability and host availability. We are also applying phenological models that can be used to analyze how climate change and increased weather variability might affect temporal sequencing of pest development and subsequent population response. Being able to produce robust predictions of such shifts will improve the efficacy of our early detection surveillance programs conducted in cooperation with States.

\section{Veterinary Services}

Veterinary Services (VS) is responsible for regulating the importation and interstate movement of animals and their products to prevent the introduction and spread of foreign animal diseases of livestock. If a foreign animal disease were to be detected in the United States, VS is responsible for responding to the outbreak in coordination with States, Tribes, and producers. VS also regulates the licensing of veterinary biologics such as vaccines. In the paragraphs below, VS outlines various ways that it is preparing for disasters such as climate change by examining the vulnerabilities that exist.

\section{Changes in the distribution of vectors:}

- Vulnerabilities: Climate change could mediate changes in the dispersal and redistribution of arthropod vectors along with the ability of them to transmit economically important pathogens, potentially allowing their spread from areas where they are already established to new locations. This change in distribution could result in significant increases in morbidity and mortality to livestock, wildlife, and people, along with a reduction in market value of animals from affected areas.

- Current measures addressing vulnerabilities: VS conducts passive-as well as some activesurveillance for diseases spread by vectors including cattle fever (babesiosis), EHDV (epizootic hemorrhagic disease virus), vesicular stomatitis virus, and blue tongue virus (BTV), and monitors reports and studies of other vector-borne diseases. This surveillance activity may help identify any changes in vector populations, and inform recommended changes to disease surveillance and 


\section{Northeast Region}

production practices. VS could identify other mitigations through further research in this area. Such projects may include using climate models and scenario analyses to identify geographic areas likely to undergo environmental changes that would lead to a higher risk of infection with selected pathogens, and simulating economic effects of potential vector and pathogen range expansion to livestock and wildlife industries.

\section{Increased interaction among wildlife livestock:}

- Vulnerabilities: Increased pest infestation, fires, and expansion of the wilderness-urban interface could alter wild animal distribution, movements, and feeding patterns, thereby increasing contact and the potential for disease exchange with agricultural animal populations.

- Current measures addressing vulnerabilities: VS is a collaborator in a new program led by APHIS Wildlife Services to investigate and mitigate agricultural and natural resource damage and disease risks from feral swine. VS is also involved in studying and responding to wildlifelivestock interactions with regard to disease transmission.

\section{Aquaculture:}

- Vulnerabilities: Marine and freshwater food fish populations have already experienced significant declines due to warming waters and the attendant effects that include acidification, oxygen depletion, algal blooms, and increased pathogen loads. These effects exacerbate the effiects of overharvesting, which has depleted many wild fish populations. Decreases in catches of wild fish places more pressure on the aquaculture industry for higher production and mitigation of health effects.

- Potential measures addressing vulnerabilities: As demands on the aquaculture industry for fish protein increases, VS will rely more heavily on coordinated efforts targeting disease control and improved health of aquacultured species. VS partners with the commercial aquaculture industry and Federal agencies and States to work collectively to protect and certify the health of farmedraised aquatic animals and facilitate their trade, and to safeguard the Nation's wild aquatic animal populations and resources.

\section{Policy and Program Development}

Policy and Program Development (PPD) performs economic, environmental, and other analyses to support the actions of the APHIS programs. PPD analyses would be more robust over time if they were better able to incorporate economic and environmental effects of climate change to relevant agricultural systems and ecosystems. Robust projections of climate change and its effect on distribution of production areas for various commodities, as well as anticipated needs for commodity movements at an international and domestic scale, can inform such economic analyses. These projections, along with information on pollinators, water and other resources, as well as effects to low-income, minority, and Tribal communities, will better inform PPD environmental analyses.

PPD is incorporating climate change into many of its environmental compliance (e.g., National Environmental Policy Act (NEPA) documents and is leading an agency-wide effort to develop guidance for addressing climate change in our NEPA documents.

\section{Wildlife Services}

The mission of APHIS Wildlife Services (WS) is to provide Federal leadership and expertise to resolve wildlife conflicts to allow people and wildlife to coexist. WS conducts program delivery, research, and other activities through its regional and State offices, the National Wildlife Research Center (NWRC) and its field stations, and through national programs. Because the work of WS is greatly influenced by distributions of wildlife, which are expected to shift as the climate changes, much of this work will be affected. The following examples reflect some of those changes that are likely to effect the Northeast: 


\section{Northeast Region}

Managing diseases spread by wildlife: Climate change will likely have dramatic effects on the distribution of both agricultural diseases of concern and on zoonotic diseases, both of which can be spread by wildlife. It is expected that some areas will experience a decrease in endemic disease risks, whereas others may experience the emergence of new diseases in areas where they were not previously documented. Given the sensitivity of insect vectors to changes in weather-related variables, it is likely that initial changes in disease distribution resulting from climate change will take place for those diseases that are vector-borne.

Staff at the NWRC is conducting surveillance and research on diseases and vectors to gather baseline data on their distribution for use in climate change models and future studies. NWRC also maintains tissue archives of wildlife samples that are made available for retrospective research on diseases to identify changes in pathogen distribution and prevalence.

Predator management: As climate changes, so may landscapes and habitats shift along with changes in prey distribution and abundance. Changes in native vegetation, and therefore forage, will alter feeding patterns of omnivorous predators such as coyotes, mountain lion, and wolves. These shifts will influence the distribution and abundance of predators and will alter the predictive ability of models related to spatial patterns, behavior, abundance, and habitat use by predators. Results of climate-informed models may be needed to inform predator management strategies in order to adapt to climate change.

NWRC researchers are gathering data on changes in species distribution and abundance, behavior, and habitat use for predators from around the country that are already affected by climate change (e.g., polar bears) and will use these studies as a foundation for incorporating climate change into studies of species found locally. NWRC is also incorporating climate change models into projections about future habitat availability for predators.

Wildlife management for aviation safety: As climate changes, so may the breeding and wintering ranges of birds that affect aviation safety. Airports and military installations should be prepared to manage new challenges associated with changes in bird ranges. Also, species' migration strategies may change. As an example, NWRC has developed migration models for osprey in relation to military aircraft movements. These very well could become outdated as climate, and therefore bird migration strategies, change. Proper habitat management is crucial to successful management of wildlife hazards to aviation. Distribution of plant species that grow on airports and military installations may change in the future. Thus, habitat management strategies may also need to adapt to a changing climate.

NWRC is gathering data on species and habitat distribution, so that changes in species ranges and migration and movement patterns should be detectable, and therefore adjust habitat management strategies accordingly. NWRC is also researching alternative land covers that could be used at airports and military installations in the Northeast and across the United States. Thus NWRC staff is determining which habitat types could be viable options in new areas as conditions change.

Wildlife management to protect agriculture: WS conducts research and management on wildlife species such as starlings and blackbirds that can have a significant effect on agricultural commodities. As climate changes, the distribution of these species as well as the agricultural crops they affect will also change. Information on population densities and distribution of target species is important for understanding how climate change will affect production of these agricultural commodities.

Wildlife management to protect sportfish: WS conducts research and management to protect valuable sportfish such as yellow perch and walleye from birds such as double-crested cormorants in the Northeast. However, as climate changes, some fisheries are likewise transitioning as fish species characteristic of warmer regions increase in prevalence. Also, ranges of invasive species may be affected by climate change. Thus, management of birds to protect sportfish will need to adapt to changing conditions brought about by climate change. 


\section{References}

Adaptation Subcommittee to the Governor's Steering Committee on climate change. (2010). A Report by the Adaptation Subcommittee to the Governor's Steering Committee on Climate Change. State of Connecticut Retrieved from Accessed at http://www.ct.gov/deep/cwp/view.asp?a=4423\&q=521742\&deepNav_GID=2121.

Alabama Precision Ag Extension. (2011). Variable-Rate Technology. Retrieved February 24, 2015, from http://www.aces.edu/anr/precisionag/VRT.php

Anderson, JT, Panetta, AM, \& Mitchell-Olds, T. (2012). Evolutionary and Ecological Responses to Anthropogenic Climate Change Update on Anthropogenic Climate Change. Plant physiology, 160(4), 1728-1740.

Anderson, P, Chai, F, Kelly, J, Incze, L, Pershing, A, \& Steneck, R. (2009). Gulf of Maine. In G. L. Jacobson, F. I.J, M. P.A., \& C. V. Schmitt (Eds.), Climate Future: An Initial Assessment (pp. 1722). Orono: University of Maine.

Bauer, S. (1997). Baby Piglet: ARS.

Bauer, S. (2006). Apples (pp. Image Number K7252-7265): USDA-ARS.

Bauer, S. (2007). Landowner Walking a Field with Nrcs Soil Conservationist. Connecticut: NRCS.

Beecher, S, Thaler, T, Griffith, G, Perry, A, Crossett, T, \& Rasker, R (Eds.). (2013). Adapting to a Changing Climate: Risks and Opportunities for the Upper Delaware River Region. Sagle, ID: Model Forest Policy Program in association with Common Waters Partnership, Pinchot Institute for Conservation, Cumberland River Compact, and Headwaters Economics.

Betts, L. (2000). Strawberries in Monterey County, Ca. California: NRCS.

Bradley, NL, Leopold, AC, Ross, J, \& Huffaker, W. (1999). Phenological Changes Reflect Climate Change in Wisconsin. Proceedings of the National Academy of Sciences of the United States of America, 96(17), 9701-9704.

Buonaiuto, F, Patrick, L, Gornitz, V, Hartig, E, Leichenko, R, \& Vancura, P. (2011). Coastal Zones. In C. Rosenzweig, W. Solecki, A. DeGaetano, M. O’Grady, S. Hassol, \& P. Grabhorn (Eds.), Responding to climate change in New York State: The ClimAID integrated assessment for effective climate change adaptation in New York State [Technical report] (pp. 121-162). Albany: New York State Energy Research and Development Authority (NYERSDA). Retrieved from Accessed at http://www.nyserda.ny.gov/climaid.

Butler, P, Iverson, L, Thompson III, F, Brandt, L, Handler, S, Janowiak, M, Shannon, D, Swanston, C, Karriker, K, Bartig, J, Connelly, S, Dijak, W, Bearer, S, Blatt, S, Brandon, A, Byers, EA, Coon, C, Culbreth, T, Daly, J, Dorsey, W, Ede, D, Euler, C, Gillies, N, Hix, DM, Johnson, C, Lyte, L, Matthews, S, McCarthy, D, Minney, D, Murphy, D, O'Dea, C, Orwan, R, Peters, M, Prasad, A, Randall, C, Reed, J, Sandeno, C, Schuler, TM, Sneddon, L, Stanley, B, Steele, A, Swaty, R, Stout, S, Teets, J, Tomon, T, Vanderhorst, JP, Whatley, J, \& Zegre, N. (2015). Central Appalachians Forest Ecosystem Vulnerability Assessment and Synthesis: A Report from the Central Appalachians Climate Change Response Framework Project Gen. Tech. Rep. NRS-146

References

Page | 54 


\section{Northeast Region}

(pp. 310). Newtown Square, PA: U.S. Department of Agriculture, Forest Service, Northern Research Station.

Byers, EA, Vanderhorst, JP, \& Streets, BP. (2007). Classification and Conservation Assessment of High Elevation Wetland Communities in the Allegheny Mountains of West Virginia: W. Va. Division of Natural Resources, Wildlife Resources Section.

Campbell, JL, Rustad, LE, Boyer, EW, Christopher, SF, Driscoll, CT, Fernandez, IJ, Groffman, PM, Houle, D, Kiekbusch, J, Magill, AH, Mitchell, MJ, \& Ollinger, SV. (2009). Consequences of Climate Change for Biogeochemical Cycling in Forests of Northeastern North America. Canadian Journal of Forest Research-Revue Canadienne De Recherche Forestiere, 39(2), 264284. doi: 10.1139/x08-104

Chiang, JM, Iverson, LR, Prasad, A, \& Brown, KJ. (2008). Effects of Climate Change and Shifts in Forest Composition on Forest Net Primary Production. Journal of Integrative Plant Biology, 50(11), 1426-1439. doi: DOI 10.1111/j.1744-7909.2008.00749.x

Coale, F, Grybauskas, A, Kratochvil, R, McHenry, S, Musgrove, C, Parker, D, Pee, D, Timmons, J, Rhoderick, J, \& Ziska, L. (2011). Agriculture. In K. Boicourt \& Z. P. Johnson (Eds.), Comprehensive strategy for reducing Maryland's vulnerability to climate change, Phase II: Building societal, economic, and ecological resilience (pp. 15-24): University of Maryland Center for Environmental Science and Maryland Department of Natural Resources.

Cogbill, CV, \& White, PS. (1991). The Latitude-Elevation Relationship for Spruce-Fir Forest and Treeline Along the Appalachian Mountain Chain. Vegetatio, 94(2), 153-175.

Cole, CT, Anderson, J, Lindroth, RL, \& Waller, DM. (2010). Rising Concentrations of Atmospheric Co2 Have Increased Growth in Natural Stands of Quaking Aspen (Populus Tremuloides). Global Change Biology, 16(8), 2186-2197.

Cornell Horticulture. (2014). Managing Climate Change on the Farm.

Cross, MS, Zavaleta, ES, Bachelet, D, Brooks, ML, Enquist, CAF, Fleishman, E, Graumlich, LJ, Groves, CR, Hannah, L, Hansen, L, Hayward, G, Koopman, M, Lawler, JJ, Malcolm, J, Nordgren, J, Petersen, B, Rowland, EL, Scott, D, Shafer, S, Shaw, MR, \& Tabor, GM. (2012). The Adaptation for Conservation Targets (Act) Framework: A Tool for Incorporating Climate Change into Natural Resource Management. Environmental Management, 50(3), 341-351. doi: $10.1007 / \mathrm{s} 00267-012-9893-7$

Davis, MB. (1983). Quaternary History of Deciduous Forests of Eastern North-America and Europe. Annals of the Missouri Botanical Garden, 70(3), 550-563.

Davis, MB, Shaw, RG, \& Etterson, JR. (2005). Evolutionary Responses to Changing Climate. Ecology, 86(7), 1704-1714. doi: 10.1890/03-0788

Division of Energy and Climate. (2014). Delaware: Climate Change Impact Assessment: Delaware Department of Natural Resources and Environmental Control.

Dukes, JS, Pontius, J, Orwig, D, Garnas, JR, Rodgers, VL, Brazee, N, Cooke, B, Theoharides, KA, Stange, EE, Harrington, R, Ehrenfeld, J, Gurevitch, J, Lerdau, M, Stinson, K, Wick, R, \& Ayres, M. (2009). Responses of Insect Pests, Pathogens, and Invasive Plant Species to Climate Change 


\section{Northeast Region}

in the Forests of Northeastern North America: What Can We Predict? Canadian Journal of Forest Research, 39(2), 231-248.

Duveneck, MJ, Scheller, RM, White, MA, Handler, SD, \& Ravenscroft, C. (2014). Climate Change Effects on Northern Great Lake (USA) Forests: A Case for Preserving Diversity. Ecosphere, 5(2), art23.

Economic Research Service. (2011). Arms Farm Financial and Crop Production Practices. Washington, DC: U.S. Department of Agriculture, Economic Research Service.

Executive Office of Energy and Environmental Affairs. (2011). Massachusetts Climate Change Adaptation Report. Retrieved from http://www.mass.gov/eea/docs/eea/energy/cca/eea-climateadaptation-report.pdf.

Franks, PJ, Adams, MA, Amthor, JS, Barbour, MM, Berry, JA, Ellsworth, DS, Farquhar, GD, Ghannoum, O, Lloyd, J, McDowell, N, Norby, RJ, Tissue, DT, \& von Caemmerer, S. (2013). Sensitivity of Plants to Changing Atmospheric Co2 Concentration: From the Geological Past to the Next Century. New Phytol, 197(4), 1077-1094. doi: 10.1111/nph.12104

Frelich, LE, \& Reich, PB. (2010). Will Environmental Changes Reinforce the Impact of Global Warming on the Prairie-Forest Border of Central North America? Frontiers in Ecology and the Environment, 8(7), 371-378. doi: 10.1890/080191

Friedline, A. (2011). Rain Cuts Early Volume, Delays Summer Harvest. The Packer. Retrieved from http://www.thepacker.com/fruit-vegetable-news/shipping-profiles/Rain-cuts-early-volumedelays-summer-harvest-125642283.html

Glick, P, Stein, BA, \& Edelson, NA (Eds.). (2011). Scanning the Conservation Horizon: A Guide to Climate Change Vulnerability Assessment. . Washington DC.: National Wildlife Federation.

Greb, P. (2008). An Adult Worker Honey Bee Collecting Pollen: ARS.

Griffin, T. (2009). Agriculture. In I. J. G.L. Jacobson, Fernandez, P.A., Mayewski, \& C.V. Schmitt (Ed.), Climate future: An initial assessment (pp. 41-44). Orono: University of Maine. Retrieved from https://www.climatechange.umaine.edu/mainesclimatefuture/.

Groffman, PM, Kareiva, P, Carter, S, Grimm, NB, Lawler, J, Mack, M, Matzek, V, \& Tallis, H. (2014). Ecosystems, Biodiversity, and Ecosystem Services. In M. J.M., T.C., Richmond, \& G.W. Yohe (Ed.), Climate change impacts in the United States: The third national climate assessment (pp. 195-219). Retrieved from http://nca2014.globalchange.gov/report/sectors /ecosystems.

Gutowski, WJ, Hegerl, GC, Holland, GJ, Knutson, TR, Mearns, LO, Stouffer, RJ, Webster, PJ, Wehner, MF, \& Zwiers, FW. (2008). Causes of Observed Changes in Extremes and Projections of Future Changes. In Thomas R. Karl, Gerald A. Meehl, Christopher D. Miller, Susan J. Hassol, Anne M. Waple, \& W. L. Murray (Eds.), Weather and Climate Extremes in a Changing Climate. Regions of Focus: North America, Hawaii, Caribbean, and U.S. Pacific Islands. Washington, DC: U.S. Climate Change Science Program and the Subcommittee on Global Change Research.

Hayhoe, K, Wake, CP, Huntington, TG, Luo, LF, Schwartz, MD, Sheffield, J, Wood, E, Anderson, B, Bradbury, J, DeGaetano, A, Troy, TJ, \& Wolfe, D. (2007). Past and Future Changes in Climate and Hydrological Indicators in the Us Northeast. Climate Dynamics, 28(4), 381-407. 


\section{Northeast Region}

He, HS, Mladenoff, DJ, \& Gustafson, EJ. (2002). Study of Landscape Change under Forest Harvesting and Climate Warming-Induced Fire Disturbance. Forest Ecology and Management, 155(1), 257270.

Heinz, C. (2008, 07/21/2010). Strategies for Managing the Effects of Climate Change on Wildlife and Ecosystems. from http://www.heinzctr.org/publications/PDF/Strategies_for_managing_effects_of_climate_change on_wildlife_Nov_4_2008.pdf

Heller, NE, \& Zavaleta, ES. (2009). Biodiversity Management in the Face of Climate Change: A Review of 22 Years of Recommendations. Biological Conservation, 142(1), 14-32.

Hellmann, JJ, Byers, JE, Bierwagen, BG, \& Dukes, JS. (2008). Five Potential Consequences of Climate Change for Invasive Species. Conservation Biology, 22(3), 534-543.

Helsel, ZR, \& Specca, D. (2009). Crop Residues as a Potential Bioenergy Resource [Fs1116]. New Brunswick.

Hicke, JA, Johnson, MC, Hayes, JL, \& Preisler, HK. (2012). Effects of Bark Beetle-Caused Tree Mortality on Wildfire. Forest Ecology and Management, 271, 81-90.

Hodgkins, G, Dudley, R, \& Huntington, T. (2003). Changes in the Timing of High River Flows in New England over the 20th Century. Journal of Hydrology, 278(1), 244-252.

Hodgkins, GA, \& Dudley, RW. (2005). Changes in the Magnitude of Annual and Monthly Streamflows in New England, 1902-2002.

Hodgkins, GA, James, IC, \& Huntington, TG. (2002). Historical Changes in Lake Ice-out Dates as Indicators of Climate Change in New England, 1850-2000. International Journal of Climatology, 22(15), 1819-1827.

Horton, R, Yohe, G, Easterling, W, Kates, R, Ruth, M, Sussman, E, Whelchel, A, Wolfe, D, \& Lipschultz, F. (2014). Ch. 16: Northeast In J. M. Melillo, T. T. C. Richmond, \& G. W. Yohe (Eds.), Climate Change Impacts in the United States: The Third National Climate Assessment (pp. 16-11-nn). Washington D.C.: U.S. Global Change Research Program.

ICF International. (2013). Greenhouse Gas Mitigation Options and Costs for Agricultural Land and Animal Production within the United States. In S. D. Biggar, D. Man, K. Moffroid, D. Pape, M. Riley-Gilbert, R. Steele, \& V. Thompson (Eds.), (Vol. Prepared under USDA Contract No. AG3142-P-10-0214). Washington DC: U.S. Department of Agriculture, Office of the Chief Economist.

Intergovernmental Panel on Climate Change. (2000). Special Report on Emissions Scenarios: A Special Report of Working Group Iii of the Intergovernmental Panel on Climate Change. In N.

Nakicenovic \& R. Swart (Eds.), (pp. 570). Cambridge University Press.

Intergovernmental Panel on Climate Change. (2006). 2006 Ipcc Guidelines for National Greenhouse Gas Inventories, Volume 4: Agriculture, Forestry and Other Land Use.

Intergovernmental Panel on Climate Change. (2007). Climate Change 2007: The Physical Science Basis: Summary for Policy Makers. New York, NY.

References

Page $\mid 57$ 


\section{Northeast Region}

Iverson, L, Prasad, A, \& Matthews, S. (2008). Modeling Potential Climate Change Impacts on the Trees of the Northeastern United States. Mitigation and Adaptation Strategies for Global Change, 13, 487-516.

Iverson, LR, \& Prasad, AM. (1998). Predicting Abundance of 80 Tree Species Following Climate Change in the Eastern United States. Ecological Monographs, 68(4), 465-485.

Iverson, LR, Prasad, AM, Matthews, SN, \& Peters, M. (2008). Estimating Potential Habitat for 134 Eastern Us Tree Species under Six Climate Scenarios. Forest Ecology and Management, 254(3), 390-406.

Iverson, LR, Prasad, AM, Matthews, SN, \& Peters, MP. (2011). Lessons Learned While Integrating Habitat, Dispersal, Disturbance, and Life-History Traits into Species Habitat Models under Climate Change. Ecosystems, 14, 1005-1020.

Iverson, LR, Schwartz, MW, \& Prasad, AM. (2004a). How Fast and Far Might Tree Species Migrate in the Eastern United States Due to Climate Change? Global Ecology and Biogeography, 13(3), 209-219.

Iverson, LR, Schwartz, MW, \& Prasad, AM. (2004b). Potential Colonization of Newly Available TreeSpecies Habitat under Climate Change: An Analysis for Five Eastern Us Species. Landscape Ecology, 19(7), 787-799.

Janowiak, MK, Swanston, CW, Nagel, LM, Brandt, LA, Butler, PR, Shannon, PD, Iverson, LR, Matthews, SN, Prasad, A, \& Peters, MP. (2014). A Practical Approach for Translating Climate Change Adaptation Principles into Forest Management Actions. Journal of Forestry, 112(5), 424433.

Jarnevich, CS, \& Stohlgren, TJ. (2009). Near Term Climate Projections for Invasive Species Distributions. Biological Invasions, 11(6), 1373-1379.

Johnson, Z, Bierwagen, B, Butowski, N, Cain, C, Curson, D, Delgado, P, Hilderbrand, R, Jasinski, P, Julius, S, McGee, B, McKnight, J, Parham, T, Papiez, C, Samson, D, Secor, D, \& Stranko, S. (2011). Bay and Aquatic Ecosystems. In K. Boicourt \& Z. P. Johnson (Eds.), Comprehensive strategy for reducing Maryland's vulnerability to climate change, Phase II: Building societal, economic, and ecological resilience (pp. 35-44): University of Maryland Center for Environmental Science and Maryland Department of Natural Resources.

Joyce, LA, Blate, GM, Littell, JS, McNulty, SG, Millar, CI, Moser, SC, Neilson, RP, O’Halloran, K, \& Peterson, DL. (2008). National Forests. In S. H. Julius, J. M. West, (eds.), J. S. Baron, L. A. Joyce, P. Kareiva, B. D. Keller, M. A. Palmer, C. H. Peterson, J. M. Scott, \& (Authors) (Eds.), Preliminary Review of Adaptation Options for Climate-Sensitive Ecosystems and Resources. A Report by the U.S. Climate Change Science Program and the Subcommittee on Global Change Research. U.S. Environmental Protection Agency, Washington, DC, USA.

Jump, AS, \& Peñuelas, J. (2005). Running to Stand Still: Adaptation and the Response of Plants to Rapid Climate Change. Ecology Letters, 8(9), 1010-1020. doi: 10.1111/j.1461-0248.2005.00796.x

Karl, TR, Meehl, GA, Miller, CD, Hassol, SJ, Waple, AM, \& Murray, WL. (2008). Weather and Climate Extremes in a Changing Climate. Regions of Focus: North America, Hawaii, Caribbean, and U. S. Pacific Islands. A Report by the U. S. Climate Change Science Program and the Subcommittee 


\section{Northeast Region}

on Global Change Research. Agronomy Journal. from

http://www.climatescience.gov/Library/sap/sap3-3/final-report/

Kirkpatrick, S. (2013). Fresh-Picked Tomatoes (Grand Bay, Ala.). Alabama: NRCS.

Kunkel, KE, Stevens, LE, Stevens, SE, Sun, L, Janssen, E, Wuebbles, D, Rennells, J, DeGaetano, A, \& Dobson, JG. (2013). Regional Climate Trends and Scenarios for the U.S. National Climate Assessment Part 1. Climate of the Northeast U.S. (pp. 142-141, 179 pp.): NOAA Technical Report NESDIS.

Kutner, D. (2008). Fire Safety Initiative: Stafford and Barnegat Townships Action Strategy: Stafford Township, Barnegat Township, New Jersey Department of Environmental Protection Forest Fire Service, and the New Jersey Pinelands Commission.

Lamont, JWJ. (2009). Overview of the Use of High Tunnels Worldwide HortTechnology, 19, 25-29.

Landscape Change Research Group. (2014). Climate Change Atlas. Delaware, Ohio: Northern Research Station, USDA Forest Service. Retrieved from www.nrs.fs.fed.us/atlas

Lapointe, G. (2013). nroc White Paper: Overview of the Aquaculture Sector in New England.

Lee, JC, Bruck, DJ, Dreves, AJ, Ioriatti, C, Vogt, H, \& Baufeld, P. (2011). In Focus: Spotted Wing Drosophila, Drosophila Suzukii, across Perspectives. Pest Science Management, 67, 1349-1351.

Lenihan, JM, Bachelet, D, Neilson, RP, \& Drapek, R. (2008). Simulated Response of Conterminous United States Ecosystems to Climate Change at Different Levels of Fire Suppression, Co(2) Emission Rate, and Growth Response to Co(2). Global and Planetary Change, 64(1-2), 16-25.

Locke, J. (2007). A Retail Greenhouse Section of a Production Greenhouse Facility in Northwest Ohio Shows Some of the Diversity of Floricultural Plants Produced in That Region. Ohio: ARS.

Lynn, K, Daigle, J, Hoffman, J, Lake, F, Michelle, N, Ranco, D, Viles, C, Voggesser, G, \& Williams, P. (2013). The Impacts of Climate Change on Tribal Traditional Foods. Climatic Change, 120, 545556.

Manomet Center for Conservation Sciences. (2010). Climate Change and Massachusetts Fish and Wildlife: Habitat and Species Vulnerability (Volume 2) (pp. 59). Massachusetts Division of Fisheries and Wildlife, : Commonwealth of Massachusetts.

Manomet Center for Conservation Sciences. (2012). The Vulnerabilities of Fish and Wildlife Habitat in the Northeast to Climate Change: A Report to the Northeastern Association of Fish and Wildlife Agencies and to the North Atlantic Landscape Conservation Cooperative (pp. 183). Plymouth, MA: Manomet Center for Conservation Sciences.

McKenney-Easterling, M, DeWalle, DR, Iverson, LR, Prasad, AM, \& Buda, AR. (2000). The Potential Impacts of Climate Change and Variability on Forests and Forestry in the Mid-Atlantic Region. Climate Research, 14(3), 195-206.

McLachlan, JS, Clark, JS, \& Manos, PS. (2005). Molecular Indicators of Tree Migration Capacity under Rapid Climate Change. Ecology, 86(8), 2088-2098. 


\section{Northeast Region}

McMahon, SM, Parker, GG, \& Miller, DR. (2010). Evidence for a Recent Increase in Forest Growth. Proceedings of the National Academy of Sciences, 107(8), 3611-3615.

Melillo, JM, Richmond, TC, \& Yohe, GW (Eds.). (2014). Climate Change Impacts in the United States: The Third National Climate Assessment: U.S. Global Change Research Program.

Millar, CI, Skog, KE, McKinley, DC, Birdsey, RA, Swanston, C, Hines, SJ, Woodall, CW, Reinhart, ED, Peterson, DL, \& Vose, JM. (2012). Adaptation and Mitigation. In J. M. Vose, D. L. Peterson, \& T. Patel-Weynand (Eds.), Effects of Climatic Variability and Change on Forest Ecosystems: A Comprehensive Science Synthesis for the U.S. Forest Sector (pp. 7-95). Portland, OR: U.S. Department of Agriculture, Forest Service, Pacific Northwest Research Station.

Millar, CI, Stephenson, NL, \& Stephens, SL. (2007). Climate Change and Forests of the Future: Managing in the Face of Uncertainty. Ecological Applications, 17(8), 2145-2151.

Morelli, TL, Yeh, S, Smith, NM, Hennessy, MB, \& Millar, CI. (2012). Climate Project Screening Tool: An Aid for Climate Change Adaptation Res. Pap. PSW-RP-263 (pp. 29 ). Albany, CA: U.S. Department of Agriculture, Forest Service, Pacific Southwest Research Station.

Moritz, MA, Parisien, M-A, Batllori, E, Krawchuk, MA, Van Dorn, J, Ganz, DJ, \& Hayhoe, K. (2012). Climate Change and Disruptions to Global Fire Activity. Ecosphere, 6(6), 22.

Murphy, HT, VanDerWal, J, \& Lovett-Doust, J. (2010). Signatures of Range Expansion and Erosion in Eastern North American Trees. Ecology Letters, 13(10), 1233-1244. doi: 10.1111/j.14610248.2010.01526.x

Nash, J, \& Galford, G. (2014). Agriculture and Food Systems. In A. H. In G.L. Galford, S. Carlson, S. Ford, J. Nash, E. Palchak, S. Pears, K. Underwood, \& D.V. Baker (Ed.), Considering Vermont's future in a changing climate: The first Vermont climate assessment (pp. 156-175). Burlington: Gund Institute for Ecological Economics.

National Agricultural Statistics Service. (2009). 2007 Census of Agriculture United States Summary and State Data (51 ed., Vol. 1). Washington D.C.: U.S. Department of Agriculture.

National Agricultural Statistics Service. (2014a). 2012 Census of Agriculture. Washington DC. : Retrieved from http://www.agcensus.usda.gov/Publications/2012/.

National Agricultural Statistics Service. (2014b). Field Crops Final Estimates 2007-2012 Statistical Bulletin (Vol. 1044): U.S. Department of Agriculture, National Agricultural Statistics Service.

National Agricultural Statistics Service. (2014c). State and County Profiles. Retrieved from: http://www.agcensus.usda.gov/Publications/2012/Online_Resources/County_Profiles/

National Agricultural Statistics Service. (2014d). State Profile: Maine. Retrieved from: http://www.agcensus.usda.gov/Publications/2012/Online Resources/County Profiles/Maine/cp99 $\underline{023 . p d f}$

National Oceanic and Atmospheric Administration. (2015). Global Surface Temperature Anomalies. Retrieved March 13, 2015, 2015, from http://www.ncdc.noaa.gov/monitoring-

references/faq/anomalies.php 
Natural Resources Workgroup of the Adaptation Subcommittee to the Governor's Steering Committee on Climate Change. (2010). The Climate Change Impacts on Connecticut Natural Resources (Appendix D).

Nearing, MA, Pruski, FF, \& O'Neal, MR. (2004). Expected Climate Change Impacts on Soil Erosion Rates: A Review. . Journal of Soil and Water Conservation, 59, 43-50.

New Hampshire Fish and Game Department. (2013). Ecosystems and Wildlife Climate Change Adaptation Plan: Amendment to the New Hampshire Wildlife Action Plan (pp. 133). Concord, NH: New Hampshire Fish and Game Department.

New Jersey Climate Adaptation Alliance. (2014a). Stakeholder Engagement Report: Agriculture. Climate Change Preparedness in New Jersey (N. J. C. A. Alliance, Trans.). In M. B. Kaplan, M. Robson, \& R. Cheyne (Eds.). New Brunswick: Rutgers University.

New Jersey Climate Adaptation Alliance. (2014b). A Summary of Climate Change Impacts and Preparedness Opportunities for the Agricultural Sector in New Jersey (N. J. C. A. Alliance, Trans.): Rutgers University.

Nichols, B. (2000a). Agriculture and Homeowners Are Neighbors in Pa. Pennsylvania: NRCS.

Nichols, B. (2000b). Dairy Cow. Pennsylvania: NRCS.

Norby, RJ, \& Zak, DR. (2011). Ecological Lessons from Free-Air Co2 Enrichment (Face) Experiments. Annual Review of Ecology, Evolution, and Systematics, 42, 181-203.

Notaro, M, Lorenz, D, Hoving, C, \& Schummer, M. (2014). Twenty-First-Century Projections of Snowfall and Winter Severity across Central-Eastern North America*,+. Journal of Climate, 27(17), 6526-6550.

Ogden, A, \& Innes, J. (2008). Climate Change Adaptation and Regional Forest Planning in Southern Yukon, Canada. Mitigation and Adaptation Strategies for Global Change, 13(8), 833-861. doi: 10.1007/s11027-008-9144-7

Ollinger, S, Goodale, C, Hayhoe, K, \& Jenkins, J. (2008). Potential Effects of Climate Change and Rising $\mathrm{Co} 2$ on Ecosystem Processes in Northeastern U.S. Forests. Mitigation and Adaptation Strategies for Global Change, 13(5), 467-485.

Pan, Y, Birdsey, R, Hom, J, \& McCullough, K. (2009). Separating Effects of Changes in Atmospheric Composition, Climate and Land-Use on Carbon Sequestration of Us Mid-Atlantic Temperate Forests. Forest Ecology and Management, 259(2), 151-164.

Pedlar, JH, McKenney, DW, Aubin, I, Beardmore, T, Beaulieu, J, Iverson, L, O'Neill, GA, Winder, RS, \& Ste-Marie, C. (2012). Placing Forestry in the Assisted Migration Debate. Bioscience, 62(9), 835-842.

Perry, KB. (1998). Basics of Frost and Freeze Protection for Horticultural Crops Hort Technology, 8, 5.

Peterson, DL, Millar, CI, Joyce, LA, Furniss, MJ, Halofsky, JE, Neilson, RP, \& Morelli, TL. (2011). Responding to Climate Change on National Forests: A Guidebook for Developing Adaptation Options (pp. 109). Portland, OR: USDA Forest Service Pacific Northwest Research Station.

References

Page $\mid 61$ 


\section{Northeast Region}

Regional IPM Centers. (2013). National Road Map for Integrated Pest Management.

Reusch, T, Ehlers, A, Hämmerli, A, \& Worm, B. (2005). Ecosystem Recovery after Climatic Extremes Enhanced by Genotypic Diversity. Proceedings of the National Academy of Sciences of the United States of America, 102(8), 2826-2831.

Ribaudo, M, Delgado, J, Hansen, L, Livingston, M, Mosheim, R, \& Williamson, J. (2011). Nitrogen in Agricultural Systems: Implications for Conservation Policy (Vol. ERS Report Number 127): U.S. Department of Agriculture, Economic Research Service.

Rittenhouse, CD, \& Rissman, AR. (2015). Changes in Winter Conditions Impact Forest Management in North Temperate Forests. Journal of Environmental Management, 149(0), 157-167.

Roberts, T, Birky, K, Damm, K, Fisher, N, Hojagyedliyev, D, Knee, J, Marciante, L, Marshall, C, Mattison, C, McCracken, C, Mersha, S, Pagan, J, \& Poyar, K. (2010). Summary: Preliminary Assessment of Rhode Islands's Vulnerability to Climate Change and Its Options for Adaptation Action: Brown University Center for Environmental Studies.

Rodenhouse, NL. (2009). Climate Change Effects on Native Fauna of Northeastern Forests. Canadian Journal of Forest Research, 39(2), 249-263.

Root, TL, Price, JT, Hall, KR, Schneider, SH, Rosenzweig, C, \& Pounds, JA. (2003). Fingerprints of Global Warming on Wild Animals and Plants. Nature, 421(6918), 57-60.

Rosenzweig, C, Iglesias, A, Yang, X, Epstein, PR, \& Chivian, E. (2001). Climate Change and Extreme Weather Events; Implications for Food Production, Plant Diseases, and Pests. Global change \& human health, 2(2), 90-104.

Rustad, L, Campbell, J, Dukes, JS, Huntington, T, Fallon Lambert, K, Mohan, J, \& Rodenhouse, N. (2012). Changing Climate, Changing Forests: The Impacts of Climate Change on Forests of the Northeastern United States and Eastern Canada (pp. 48). Newtown Square, PA: U.S. Department of Agriculture, Forest Service, Northern Research Station.

Ryan, MG, \& Vose, JM. (2012). Effects of Climatic Variability and Change. In J. M. Vose, D. L. Peterson, \& T. Patel-Weynand (Eds.), Effects of Climatic Variability and Change on Forest Ecosystems: A Comprehensive Science Synthesis for the U.S. Forest Sector (pp. 7-95). Portland, OR: U.S. Department of Agriculture, Forest Service, Pacific Northwest Research Station.

Scheller, RM, \& Mladenoff, DJ. (2008). Simulated Effects of Climate Change, Fragmentation, and InterSpecific Competition on Tree Species Migration in Northern Wisconsin, USA. Climate Research, 36(3), 191-202. doi: 10.3354/cr00745

Schwartz, MD, R.Ahas, \& Aasa, A. (2006). Onset of Spring Starting Earlier across the Northern Hemisphere. Global Change Biology, 12(2), 343-351.

Schwartz, MW, Hellmann, JJ, McLachlan, JM, Sax, DF, Borevitz, JO, Brennan, J, Camacho, AE, Ceballos, G, Clark, JR, \& Doremus, H. (2012). Managed Relocation: Integrating the Scientific, Regulatory, and Ethical Challenges. Bioscience, 62(8), 732-743. 
Scott, D, Dawson, J, \& Jones, B. (2008). Climate Change Vulnerability of the Us Northeast Winter Recreation-Tourism Sector. Mitigation and Adaptation Strategies for Global Change, 13(5-6), 577-596.

Seppälä, R, Buck, A, \& Katila, P. (2009). Adaptation of Forests and People to Climate Change. A Global Assessment Report. (Vol. IUFRO World Series Volume 22). Helsinki: International Union of Forest Research Organizations.

Shifley, SR, Aguilar, FX, Song, N, Stewart, SI, Nowak, DJ, Gormanson, DD, Moser, WK, Wormstead, S, \& Greenfield, EJ. (2012). Forests of the Northern United States. Gen. Tech. Rep. NRS-90 (pp. 202). Newtown Square, PA: U.S. Department of Agriculture, Forest Service, Northern Research Station.

Skinner, C, DeGaetano, A, \& Chabot, B. (2010). Implications of Twenty-First Century Climate Change on Northeastern United States Maple Syrup Production: Impacts and Adaptations. Climatic Change, 100(3-4), 685-702. doi: 10.1007/s10584-009-9685-0

Snyder, RL, \& Melo-Abreu, JPd. (2005). Frost Protection: Fundamentals, Practice and Economics Vol 1. : Food and Agriculture Organization of the United Nations Rome.

Stein, BA, Glick, P, Edelson, N, \& Staudt, A (Eds.). (2014). Climate Smart Conservation: Putting Adaptation Principles into Practice. Washington, D.C.: Climate-Smart Conservation Workgroup.

Swanston, C, Janowiak, MK, Iverson, L, Parker, L, Mladenoff, D, Brandt, L, Butler, P, Pierre, MS, Prasad, A, Matthews, S, Peters, M, Higgins, D, \& Dorland, A. (2011). Ecosystem Vulnerability Assessment and Synthesis: A Report from the Climate Change Response Framework Project in Northern Wisconsin. Gen. Tech. Rep. NRS-82. Newtown Square, PA: United States Department of Agriculture, Forest Service, Northern Research Station.

Swanston, CW, \& Janowiak, MK. (2012). Forest Adaptation Resources: Climate Change Tools and Approaches for Land Managers (Vol. Gen. Tech. Rep. NRS-87). Gen. Tech. Rep. NRS-87. Newtown Square, PA: U.S. Department of Agriculture, Forest Service, Northern Research Station.

Tang, Y, Zhong, S, Luo, L, Bian, X, Heilman, WE, \& Winkler, J. (2015). The Potential Impact of Regional Climate Change on Fire Weather in the United States. Annals of the Association of American Geographers, 105(1), 1-21.

Tetra Tech Inc. (2013). Climate Change Adaptation Framework: Full Report (pp. 157). Montpelier, VT: Vermont Agency of Natural Resources.

Tilman, D. (1996). Biodiversity: Population Versus Ecosystem Stability. Ecology, 77(2), 350-363. doi: $10.2307 / 2265614$

Tilman, D. (1999). The Ecological Consequences of Changes in Biodiversity: A Search for General Principles. Ecology, 80(5), 1455-1474.

Troutlodge Inc. (2013). Atlantic Salmon: ARS.

Trumble, JT, \& Butler, CD. (2009). Climate Change Will Exacerbate California's Insect Pest Problems. California Agriculture, 63(2), 73-38. doi: 10.3733/ca.v063n02p73 


\section{Northeast Region}

U.S. Census Bureau. (2014). Geography. Retrieved June 2, 2015, from https://www.census.gov/geography.html

U.S. Department of Agriculture. (2011). U.S. Agriculture and Forestry Greenhouse Gas Inventory: 19902008 (C. C. P. Office, Trans.) (Vol. Technical Bulletin No., 1930, pp. 159): U.S. Department of Agriculture, Office of the Chief Economist.

U.S. Department of Agriculture. (2014a). Frequently Asked Questions. Census of Aquaculture. from www.agcensus.usda.gov/Publications/Census of Aquaculture/

U.S. Department of Agriculture. (2014b). Quantifying Greenhouse Gas Fluxes in Agriculture and Forestry: Methods for Entity-Scale Inventory. In M. Eve, D. Pape, M. Flugge, R. Steele, D. Man, M. Riley-Gilbert, \& S. Biggar (Eds.), (Vol. Technical Bulletin Number 1939, pp. 606). Washington, DC: U.S. Department of Agriculture, Office of the Chief Economist.

U.S. Environmental Protection Agency. (2010). Inventory of U.S. Greenhouse Gas Emissions and Sinks: 1990-2008 (Vol. EPA 430-R-14-003). Washington, DC: U.S. Environmental Protection Agency.

U.S. Environmental Protection Agency. (2014). Inventory of U.S. Greenhouse Gas Emissions and Sinks: 1990-2012 (pp. 529). Washington D.C.: U.S. Environmental Protection Agency

U.S. Forest Service. (2012). Future of America's Forest and Rangelands: Forest Service 2010 Resources Planning Act Assessment (Vol. General Technical Report WO-87, pp. 198). Washington, DC:

U.S. Department of Agriculture, Forest Service.

Union of Concerned Scientists. (2008). Climate Change in Pennsylvania: Impacts and Solutions for the Keystone State. Cambridge, MA.

Vanuga, J. (2002). Poultry (pp. A total of 10,000 turkeys are raised in each building in Benton, Arkansas. Manure and wood chips used for bedding are then composted and used for fertilizer on adjacent pastures.). Arkansas: NRCS.

Vose, JM, Peterson, DL, \& Patel-Weynand, T. (2012). Effects of Climatic Variability and Change on Forest Ecosystems: A Comprehensive Science Synthesis for the U.S. Forest Sector. Portland, OR: U.S. Department of Agriculture, Forest Service, Pacific Northwest Research Station.

Walthall, CL, Hatfield, J, Backlund, P, Lengnick, L, Marshall, E, Walsh, M, Adkins, S, Aillery, M, Ainsworth, EA, Ammann, C, Anderson, CJ, Bartomeus, I, Baumgard, LH, Booker, F, Bradley, B, Blumenthal, DM, Bunce, J, Burkey, K, Dabney, SM, Delgado, JA, Dukes, J, Funk, A, Garrett, K, Glenn, M, Grantz, DA, Goodrich, D, Hu, S, Izaurralde, RC, Jones, RAC, Kim, S-H, Leaky, ADB, Lewers, K, Mader, TL, McClung, A, Morgan, J, Muth, DJ, Nearing, M, Oosterhuis, DM, Ort, D, Parmesan, C, Pettigrew, WT, Polley, HW, Rader, R, Rice, C, Rivington, M, Rosskopf, E, Salas, WA, Sollenberger, LE, Srygley, R, Stöckle, C, Takle, ES, Timlin, D, White, JW, Winfree, R, Wright-Morton, L, \& Ziska, LH. (2012). Climate Change and Agriculture in the United States: Effects and Adaptation. Usda Technical Bulletin 1935. . (Technical Bulletin 1935). Washington, DC. .

Walther, G-R, Post, E, Convey, P, Menzel, A, Parmesan, C, Beebee, TJC, Fromentin, J-M, HoeghGuldberg, O, \& Bairlein, F. (2002). Ecological Responses to Recent Climate Change. Nature, 416(6879), 389-395. 


\section{Northeast Region}

Wang, GG, Chhin, S, \& Bauerle, WL. (2006). Effect of Natural Atmospheric Co2 Fertilization Suggested by Open-Grown White Spruce in a Dry Environment. Global Change Biology, 12(3), 601-610.

Weed, AS, Ayres, MP, \& Hicke, JA. (2013). Consequences of Climate Change for Biotic Disturbances in North American Forests. Ecological Monographs, 83(4), 441-470. doi: 10.1890/13-0160.1

White, M, Running, S, \& Thornton, P. (1999). The Impact of Growing-Season Length Variability on Carbon Assimilation and Evapotranspiration over 88 Years in the Eastern Us Deciduous Forest. International Journal of Biometeorology, 42(3), 139-145.

Williams, JW, Shuman, BN, Webb, TI, Bartlein, PJ, \& Leduc, PL. (2004). Late Quaternary Vegetation Dynamics in North America: Scaling from Taxa to Biomes. Ecological Monographs, 74, 309334.

Wisconsin Initiative on Climate Change Impacts. (2011). Wisconsin's Changing Climate: Impacts and Adaptation.

Wolfe, DW, Comstock, J, Lakso, A, Chase, L, Fry, W, Petzoldt, C, Leichenko, R, \& Vancura, P. (2011). Agriculture. In W. S. C. Rosenzweig, A DeGaetano, M. O’Grady, S. Hassol, \& P. Grabhorn (Ed.), Responding to climate change in New York State: The ClimAID integrated assessment for effective climate change adaptation in New York State [Technical report]. Albany: New York State Energy Research and Development Authority (NYERSDA). Retrieved from http://www.nyserda.ny.gov/climaid.

Woodall, C, Zhu, K, Westfall, J, Oswalt, C, D’Amato, A, Walters, B, \& Lintz, H. (2013). Assessing the Stability of Tree Ranges and Influence of Disturbance in Eastern Us Forests. Forest Ecology and Management, 291, 172-180.

Zhu, K, Woodall, CW, \& Clark, JS. (2011). Failure to Migrate: Lack of Tree Range Expansion in Response to Climate Change. Global Change Biology, 1042-1052. doi: 10.1111/j.13652486.2011.02571.x 